University of Louisville

ThinkIR: The University of Louisville's Institutional Repository

Electronic Theses and Dissertations

1938

\title{
The activity program versus the traditional method of instruction at the second grade level.
}

Ruth Marie Martin

University of Louisville

Follow this and additional works at: https://ir.library.louisville.edu/etd

Part of the Educational Methods Commons

\section{Recommended Citation}

Martin, Ruth Marie, "The activity program versus the traditional method of instruction at the second grade level." (1938). Electronic Theses and Dissertations. Paper 1834.

https://doi.org/10.18297/etd/1834

This Master's Thesis is brought to you for free and open access by ThinkIR: The University of Louisville's Institutional Repository. It has been accepted for inclusion in Electronic Theses and Dissertations by an authorized administrator of ThinkIR: The University of Louisville's Institutional Repository. This title appears here courtesy of the author, who has retained all other copyrights. For more information, please contact thinkir@louisville.edu. 
UNIVERSITY OF LOUISVILIE

THE ACTIVITY PROGRAM VERSUS THE TRADITIONAL METHOD OF INSTRUCTION AT THE SECOND GRADE LEVEL

\author{
A Dissertation \\ Submitted to the Faculty \\ of the Graduate School of the University of Loulsville \\ In Partial Fulfillment of the \\ Requirements for the Degree \\ of Master of Arts
}

Department of Education

By

RUTH MARIE MARTIN

Year

1938 
Name of Student: Ruth Marle Martin

Title of Thesis: The Activity Program Versus The Traditional Method of Instruction at The Second Grade Level.

Name of Director:

Approved by a Reading Committee composed of the following members:

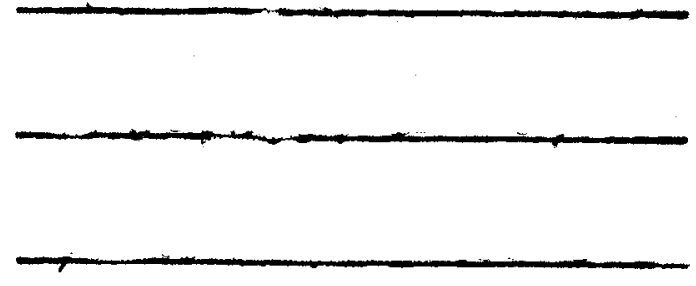

Representative of the Department of English:

Date: June, 1938. 
THE ACTIVITY PROGRAM VERSUS THE TRADITIONAL METHOD OF INSTRUCTION AT THE SECOND GRADE LEVEL 
TABLE OF CONTENTS

Page

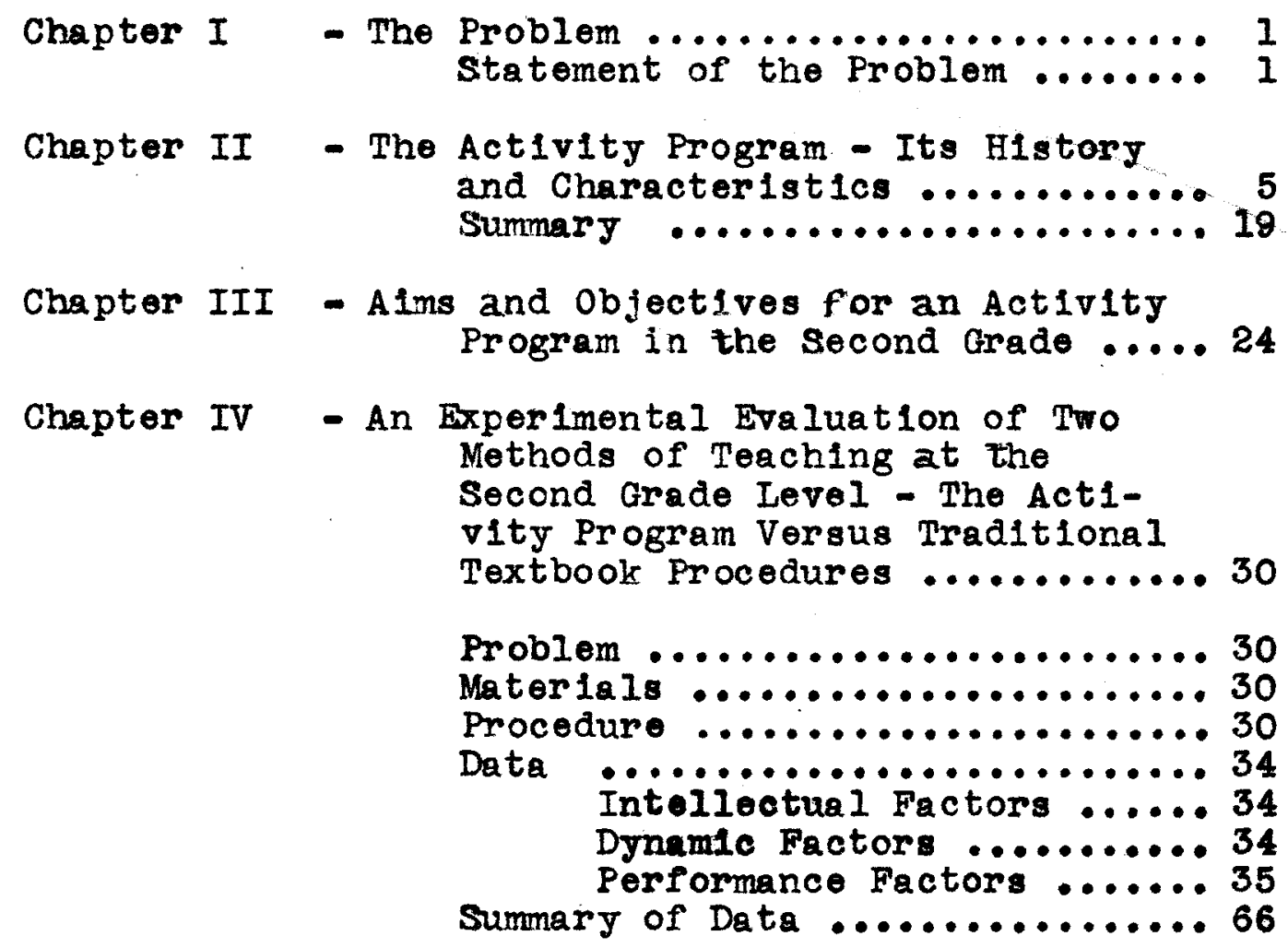

Chapter v - summary ..................... 77

The History $\ldots \ldots \ldots \ldots \ldots . . . . .77$

Comparison of the Activity

Program and the Traditional

Textbook Method .............78

Alms of an Activity Program at

the Second Grade Level .......78 78

The Experiment .............. 79

Findings $\ldots \ldots \ldots \ldots \ldots \ldots \ldots . \ldots . \ldots . \ldots 8$

Conclusions ................. 85

Chepter VI - Appendix A - Units for Activity

Program .................. 87

Unit I - The Library ........ 89

Unit II - The Dry Goods Store ..130

Unit III - The Post office ..... 156 
Appendix B - Traditional Method .. 181

A Da11y Schedule .......... 181 Grouping Acc ording to

Reading Ability ........... 182

Methods of Presenting

Reading Lessons ........... 184

Grouping According to

Arithmetic Ability ......... 190

Appendix C - Data for Chlldren of

the Activity Program and

Traditional Textbook Method .195-196

Chapter VII - Blbllography ................. 197 


\section{IIST OF TABLES}

TABIE

Two groups of second grade children at

Page the beginning of experimental period.

I Iife Ages $\ldots \ldots \ldots \ldots \ldots \ldots \ldots \ldots \ldots \ldots \ldots \ldots$

II Intelifgence Quotients ............

III Achlevement Ages .................

IV Reading scores ................

V Ar1thmet1c scorer $\ldots \ldots \ldots \ldots \ldots \ldots \ldots \ldots$

VI Language Usage Scores ..............

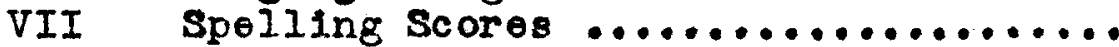

VIII Soclal Quotients .................

$\mathbf{I X}$

$\mathbf{X}$

Personality Ratings

on Ratings $\ldots \ldots \ldots \ldots \ldots \ldots \ldots \ldots$

XI Initlativo Ratings ..............

XII Pup11 Participation Ratings .........

XIII Pup1l Opinion Ratings .............

XIV Interest Ratings ................

XV Teacher Ratings on Scholarship ......

Two groups of second grade children at the end of experimental period.

XVI Achievement Ages ................

XVII Reading scores ..................

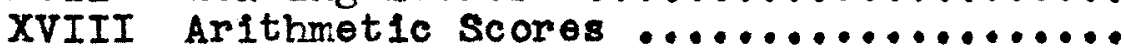

XIX Language Usago Scoros ..............

$\mathrm{XX} \quad$ SpeIling scores $\ldots \ldots \ldots \ldots \ldots \ldots \ldots \ldots \ldots$

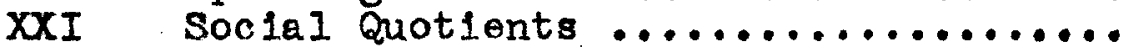

XXII Porsonal1ty Ratings ..............

XXIII Cooperation Ratings .............

XXIV Initiative Ratings ..............

XXV Pup1I Participation Ratings ..........

XXVI Pup11 Opinion Ratings .............

XXVII Interest Ratings ...............

XXVIII Teacher Ratings .................

XXIX Summary for Tegts on Units of

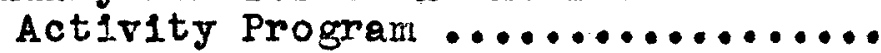

XXX Summary of Inft1al Data ...........

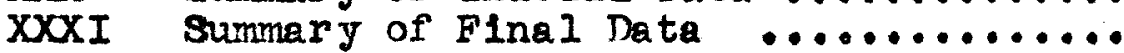

XXXII Ab1lity Grouping for Reading .........

XXXIII Ab111ty Grouping for Arithmet1c ....... 


\section{IIST OF CHARTS}

CHART

Page

I

Mean Achievement of Equated Groups in

Reading, Arithmetic, Language

Usage, Spelling, and Teacher

Ratings

71

II Social Quotients of Two Groups of Second Grade Children at the Beginning and End of Experimental

Perlods

III Personality Ratings of Two Groups of second Grade Chllaren at the Beginning and Fnd of Experimental Period

Performance Factors of Two Groups of Socond Grade Children at the Beginning and End of Experimental 


\section{LIST OF ILLUSTRATIONS}

\section{FIGURES}

$\mathbf{I}$

A Group of Children Making Posters - Library Unit . following page 95

II

A Group of Children Maiking Chairs and Another Group Making Library Cards ....precoding page 99

III

A Group of Boys Painting Book-shelves and BenchesLibrary Unit .......... following page 99 Buying and Selling ..... following page 136

VI

A Group of Children SewingDry Goods Store Unit ... following page 138

A Story Composed by the Children - Post office Unit 
STATEMENT OF PROBLEM 


\section{CHAPTER I \\ STATEMENT OF PROBLEM}

This study is concerned with:

A. What is the activity program as defined in educational literature?

B. What are the aims and objectives of the activity program as contrasted with the traditional textbook method of teaching?

c. What are the values of the activity program at the second grade level in a Loulsville school as compared with the traditional method of teaching?

D. What are the practical applications of the activity program in terms of the Loulsville Public Schools at the second grade level?

In answering " $A$ " and " $B$ " analysis was made of the writings of educational leaders found in educational and psychological books and journals from 1900 to 1938. These findings are given in Chapter II. No attempt was made to cover the entire fleld of educational Iiterature, but only those portions of Iiterature dealing specifically with the activity program and with movements leading up to it. The literature reviewed here should be thought of as a sampling rather than a complete study of the related literature in this fleld since any complete analysis of the Iiterature bearing upon the development of the activity program would involve examination of all educational 
Iiterature of the past one hundred years or more and would be quite beyond the limits of a study such as this。

In answering " $C$ " above, two groups of twenty children each, paired for chronological age,Intelifgence quotient, mental age, achlevement age, soclal development, personality adjustment, cooperation, interest, initiative, pup1l participation, and pup1l opinion were taught by the writer for one semester each, one group being taught by the traditional textbook method as describod in Appendix " $B$ " of this thesis, the other by the activity method described in Appendix "A" using the units outined. Reasons for these procedures are given in Chapter IV.

In general, analysis of the literature Indicates that not only are the phllosophies underlying the activity program radicaliy different from those of the traditional method, but the procedures employed by the two methods are markedly dissimilar, as much so, at least, as is indicated by the results of the experiment reported in Chapter IV.

Results of this study: (Iiterature-analysis and experiment).

A. That the activity program is markedly different from the traditional procedure and that it is more representative of modern education and psychological 
thought than is the traditional procedure.

B. That the basic procedures of the activity program may be employed at the second grade level.

C. That results from this type of teaching maJ reasonably be expected to be more effective than the traditional textbook method in terms of scores on standard tests of reading, vocabulary, language, speliling, arithmetic, social development, personality adjustment, and as judged by teacher's ratings of educational goals such as cooperation, initiative, interest, pupil participation, and pupil opinion.

While it is not contended that these findings are conclusive to the extent that they may be considered applicable to all schools or teachers, they are significant in terms of the present experimental procedures. That the writer may have been prejudiced in favor of the activity program and as a result may have taught more effectively by this method than by the traditional method is recognized as a possibility, though every effort was made to guard against it as described in Chapter IV. In view of the fact that most of the writer's ten years of teaching in elementary grades have been by the traditional method, and since she was unaware at the outset of the investigation of any such bias, this seems unlikely however. It is/justifiable, apparently, to conclude that the activity program method of teaching as outlined in the present study is markedly superior to the traditional method with conditions as described (children, teacher, supervisor, 
and facilities), and that it might be expected to be equally effective for other teachers under similar conditions. 
THE ACTIVITY PROGRAM - ITS HISTORY AND CHARACTERISTICS 


\section{CHAPTER II}

THE ACTIVITY PROGRAM - ITS HISTORY AND CHARACTERISTICS

With increasing inclusiveness the movement for child activity is settling over the school systems of the world. The development since 1875 of a freer type of education in America rests upon the gradual accumalation of the influence of earlier educationsl reformers, especially of the Europeans - Pestalozz1, Herbart, and Froebel. Francis W. Parker first interpreted the principles of activity for America: "As director of Cook County Nomal School of Chicago about 1883 he worked out, put into practice, and taught his teachers a theory of education along the lines which Pestalozz1 and Froebel had developed, making native endowment of the child rather than the curriculum the center of attention on the part of the educator."I.

After the death of Colonel Parker, John Dewey succerded him as Director of the School of Education in 1902. Dewey was a clear thinker but not so good in administrative 1deas. Nevertheless the activity movenent actually crystallized in the "child growth" philosophy of John Dewey as expressed in his two books, School and Society, and The Child and The Curriculum. In the former, he promlgated the new educational doctrine of learning through doing, "emphasizing the social as well as the intellectual values necessary to education in

1. Hissong, Clydo; The Activity Movement, p.I. 
a democracy."2 In the latter he showed that the curriculum material must be developed around the child as a center.

Dewey tested his philosophy in the Laboratory School at the University of Chicago and initiated what has resulted in a far-reaching, organized reaction against the domination and formalism of the traditional school. The basic assumptions upon which the Laboratory School was organized were that the school must meet the needs of the child and that the best school life is that which most closely approximates good home IIfe. 3 It was assumed that in Dewey's school the children would be more completely living if they took over the usual tasks of their natural 11fe. They were not to be chained to a rigid system of subject matter but were to be left free to follow their own desires within the Iimits of various home tasks and the play of other children.4

There was a reaction against Dewey's

school; this was because the critics had been accustomed to the traditional school based upon the point of view that "Subject matter furnishes the end, and determines the method. The child is simply the immature being who is to be matured; ho is the superficial being who is to

2. Cobb, Stanwood. The New Leaven. p.13.

3. Dewey, John, School and soc1ety.

4. Hissong, CIyde. ep.cit., p.2. 
be deepened; his is a narrow experience which is to be widened. It is his to receive, to accept. His part is fulfilled when he is ductile and docile." 5

The congtrasting position stated a new

philosophy. "The child is the starting point, the center, and the end. His development, bis growth, is the 1deal. It alone furnishes a standard. To the growth of the child all studies are subservient; they are instruments valued as they serve the needs of growth. Personality,character, is more than subject matter. Not knowledge or information but self-realization, is the goal. To possess all the world of knowledge and lose one's self is as awful a fate in education as in religion. Moreover, subject matter never can be gotten into the child from without. Learning is active!" The life of the school was to be active, not passive; the chllaren were to work, not merely 11sten. The curriculum was to be organized around four chief impulses: "the social instinct of the children," "the instinct of making - the constructive impulse," "the expressive instinct - the art instinct, and in the "Impulse toward inquiry, or finding out things :"

In 1904 Professor Dewey left the University of Chicago to become professor of phllosophy at Columbia University. From 1904 to 1806, President Harper directed the School of Education and was succeeded from 1906 to 1909 by President H. P. Judson. In 1909 the school

5. Dewey, John, The Child and Zhe Curriculum. p.13. 6. Ibid. p.13. 
was reorganized and $\mathrm{Dr}$. Charles H. Judd was made director of a four-fold organization, including the two laboratory schools, the undergraduate college of education, and the graduate department of education. Under Dr. Judd's direction the interest of the school became primarily the development of the scientific study of education. Parker and Dewey had earlier advocated the use of sclent1fic methods. However, lacking the techniques of science and being, in one case, interested essentially in practical school administration and, in the other, in educational theory, they had done little more than lay the ground work for a scientific analysis of chlld learning, the reorganization of the curriculum and school administration. Under Judd's stimulation a decade and a half of active laboratory analysis of learning in reading, handwriting, and arithmetic was inaugurated. At the same time the school of Education, through its publications, The Elementary School Journal and The School Review, lent great impetus to the movement for the reorganization of the grades of the public school.7

A most outstanding piece of work in the reconstruction of the school curriculum during the past forty or fifty years was the work of the Teachers College In Now York City. The college was opened for the first reception of students on September 12, 1887. On the same day a school of observation and practice was opened, known Sixth Yearbook, Part I. pp.96,97. 
unt11 1891 as the "model school "This was a school in which "professors of education might experiment with the curriculum and methods of teaching as professors of science experiment in the laboratory." 8 In opening the Teachers College, however, it was regarded as "Important to have a school in which it was possible to illustrate improved educational principles and to demonstrate the worth of certain new theories in the training of children. In its adrocacy of manual training, domestic economy, and the natural sciences as worthy of rank with the other subjects of the curriculum, the school was in advance of its times." 9

"From the beginning, the Horace Mann group of Teachers College almed at the improvement of education through the existing subjects of study - history,geography, arithmetic, roading, etc. They did not propose to abolish them and organize new types of activitles, as did other reformers. In this procedure, its work is to be contrasted with that of the Laboratory School at Chicago under Dewey, the work of Professor Junius L. Merlam in establishing the University Elementary School at the University of Missouri in 1904. His idea was that there should be no school subjects and no school furniture."10

After 1900 the Horace Mann School, working with Professor Frank McMurray, Princlpal Henry C.Pearson,

8. Russell, J.E.: Rerchers College Record, January, 1902.-

9. National society for the Study of Education.ep.cit.p.101. 10. Ib1d, p.101. 
and Dean James E. Russell recognized the startling advances in modern civilization and the necessity for the school to train children in quick response to new social demands. The school was regarded as a laboratory in which methods could be tested. They aimed at careful observation of real things on the part of the child and securing an all-round development in which hand work was given a central position. 11

During the past few years a new and rigorous impetus has been given to the dissemination of the doctrine of educational growth in the work of Dr. William H. Kilpatrick of Teachers College, Columbia University. He has assembled and presented to teachers more concretely then any other worker the essential principles underlying the philosophy of growth through creative experience, and has integrated Into a systematic philosophy of educational method the essential ideas of biological evolution and of dynamic psychology as developed by James, Thorndike, Woodworth, and others.

Professor Kilpatrick says, "Ifife ig 1tself an affair of action. The individual, alive and alert, faces at each moment some situation that is making demands upon him and to which he responds with preferences and with efforts as an organized whole to attain these preferences. Also the on-going stream of life develops in novel fashion. Many elements, to be sure, abide or recur, but each situation 
is in some degree new. In the degree that novelty is present, old responses do not suffice, new procedures must be devised. If this is done intelligently, thinking comes into play as a guide to action. Study thus emerges, and learning results: elther how to act or how not to act, with attitudes, habits, and skills (at least begun) as appropriate attendants. Moreover this study, if it is successful in meeting its novel situation, has brought forth novelty. Its learning is essentially creative."12 In 1904 Professor J. L. Meriam attempted to work out in an eighth-grade elementary school at the University of Missour1, a school curriculum organized on a non-subject basis. For nearly twenty years this elementary school. was operated under his direction. It represented an attempt to organize a curriculum of activities for children on a new departmental basis. The school day was divided into four ninety-minute exercises. This was a sharp contrast to the large number of ten to thirty-minute exercises operating in the public schools. This lengthening of the class perlod represents an interesting and somewhat novel contribution to the creation of a more leisurely and thoughtful atmosphere in elementary classrooms. Corresponding to this four-fold division, the curriculum was divided into four types of activities: observation, play, storles, and handwork. Third Yearbook, Part II. The Activity Movement. p.200. 
The general outline for the second grade is

as follows:

1. Observation: Plant life, animal life, people, earth, and sky.

2. Play: A great varlety of games; physical exerclse, folk dancing, and freo play.

3. Storles: Reading, telling, dramatizing, singing songs, studying pictures and drawings; assembly exercises; forelgn language.

4. Handwork:

A great varlety of useful and ornamental articles are mado. Some of the materials used are paper, reed, cord textiles, raffin, wood,

In 1915 the State University of Iowa established

its sixth grade University Elementary School under the direction of Professor Ernest Horn. In 1916 the University High School was organized on 3-3 plan. In 1922 the junior primary grade or kindergarten was added. The school now has an enroliment of more than four hundred pup1ls, with a teaching staff in the elementary school of eight full-time teachers, five assistants, and one school nurse. The school is somewhat novel in that the classroom teachers are students in the university and are training primarily to become supervisors. 14

In 1914, in connection w1th the Bureau of Educational Experiments, a laboratory school was established in New York Clty under the direction of Miss Caroline Pratt called the "Play School " The name was

13. National society for the Study of Education. TwentySixth Yearbook, Part I. p.110. 14. IbId. P.IIO 
later changed to the "C1ty and Country School;" under which it now operates. The curriculum of the school has developed with the school itself. Beginning in 1914 with small groups of children classified in accordance with chronological age (instead of Grade I, II or III, the school sperks of "the sixes," "the sevens", "the eights:" meaning the six-year-olds, seven-year-olds the eight-year-olds). The school has grown year by year until now there are ten groups running from the pre-school group of three, four, and flve years, through the twelve-year-olds. These last correspond roughly to seventh-grade children. 15

In 1915 the Walden School was established by M1ss Margaret Naumburg in New York C1ty. The school began "with a group of children between the ages of three and five and grew from this foundation unt 1 now It includes the beginning of a high school department". 16 The classes in the Walden School are Iimited to sixteen boys and girls. It wasdecided that this number was about right in holding the balance between real group life and individual development. On 1ts program the Walden School carries many more subjects than do most schools. Having begun in the younger classes with great emphasis on personal creative expression, it continues to encourage special work in the arts and sciences. From each child 
a minimum of required work is expected in all the regular school subjects, whatever his chlef interests or abilities may be.

The Walden School experiment was based on the consideration of the child as a three-fold organism to be led to integration by 'positive channeling . Thus, the rounding out of personality becomes a means of true socialization from within the group. They have come to belleve that the real group life of children cannot be directed by adults from above, that the moving center of socialization in a school lies not within the will of the teacher, but within the wishes and impulses of the children, that the responsibility for the socialization of chlldren does not lie solely within the province of teachers or schools, but must be the final result of the complete functioning of all individuals in a school, and that these things are true even in a class of children as young as three years. 17

The educational principles of the school of organic education of the Falrhope School at Falrhope, Alabama, is given in the following paragraphs taken from the Twenty-sixth Yearbook, Part I, by Marietta Johnson:

"We belleve the educational program should aim to meet the need of the growing child. We believe that childhood is for itself and not a preparation for Yearbook of the National soclety for the study of Education, Part I, pp.336-339. 
adult life. Therefore, the school program must answer for the following questions:

"What does the child of any particular age need to minister to the health of his body, to preserve the integrity of the intellect, and to keep his sincerity and unselfconsciousness of spirit?

"The answer of these questions w11l constitute the curriculum of the school, and as we grow in understanding of the nature and needs of childhood, the curriculum will change.

"We believe that alI chilaren need music; therefore, we give the younger children singing and dancing, singing games and all sorts of rhythmic work. As the children grow older, this work becomes folk dancing and folk singing, with reading of notes, singing harmonies, and learning to play an instrument at about ten or twelve years of age.

"Time is given to dramatics throughout the school I1fe.

"We believe that all children need creative handwork. This is the fundamental method of thinking. Therefore, all sorts of materials are provided for selfexpression. For the very young children, merely making things of clay and sand and using blocks may be sufficient. Later, this develops into real projects, using tools and art and craft materials. The creative handwork continues through all ages to college. We belleve it should continue through the college program. Handwork should grow 
out of, or be related to, work in history, literature, etc., as far as possible.

"We believe that all children need stories. The storles for the very young children would naturally take the form of folklore, and fables, and fairy-tales; later on, the form of history, literature, and geography, after learning to read at about eight or nine years of age. This reading work would also result in composition and the study, perhaps, of grammar in the high-school period. The Iiterature, history and geography storles begun in the early years, would be replaced by the study of history, Iiterature, and science as such in the high-school and college years.

"The speech centers are developed very young. A child may learn a language other than his own at an early age, whereas he should not be obliged to read his own until he is eight or nine years of age. We would, therefore, glve the children some experience in using a fore1gn language, such as Spanish or French.

"All children need fundamental conceptions of number. The work of measuring, weighing, estimating, counting begun in the early years, would naturally require the use of figures at about eight or ten, when the mechanics of number would be acquired with great delight. Later, applied problems, and still later, the abstract problems, which are enjoyed during the high school and college years.

"In order to preserve unselfconsclousness in $-16-$ 
growth, no grades or marks should be given and no intellectual tasks sot by the teacher. The children should be grouped according to chronological age. The chlldren should provide sultable work for the group with individual variation where necessary. The child should not do as he pleases; he does not know what is good for him. In order to preserve the unity of his intellectual and emotional life, intellectual work should accompany and follow sincere interest and desire and the reward for all learning should be the inner satisfaction and the consciousness of power which comes through understanding.

"All chlldren should have free plan, so every da1ly program should include much time in the open, much time in free, self-prompted occupation, and some time to droam. The fullest social association should be given.

"Wo believe that education is Iife, growth; that the ends are immediate; that the end and process are one. We belleve that all children should have the fullest opportunity for self-expression, for joy, for delight, for intellectual stimilus through subject-matter, but wo do not belleve that children should be made self-consclous or externalized by making subject-matter an end. Our constant thought is not what do the children learn to do, but what aro the "learning" and the "doing" doing to them. 
"Wo belleve all children need nature - not so much for facts as for experience and attitude. The nature walks and talks of the little children would develop into serious nature study, gardening, and science of the older groups.

"Every schoolroom must be a health center. In the measure that the school provides activities and exercises which tend to produce a sound, accomplished, beautiful body, an intelifgent, sympathetic mind, a sweot, sincere spirit, it is educational. In the measure that it does not, it is not educational however, informational it may bo.

"We belleve that society owes all children guidance, control, instruction, association, and inspiration right conditions of growth - throughout the growing years until physical growth is completed. No child may know fallure - all must succeed. Not "what do you know", but "what do you need", should be asked, and the nature of chllahood indicates the answer." 18

American public schools are organizing from coast to coast in terms of the activity program. Those who are ploneering for this goal, and working ardently for it apparentiy belleve their battle is already fundamentally won. From the Los Angeles public schools in the West to the New York public schools in the East the struggle

18. National Society for the Study of Education, TwentySixth Yearbook, Part I. pp.349-351. 
for the re-training of teachers is on, and fulfillment of this dream seems only a matter of time.

\section{SUMMARY}

The activity program cannot be ascribed to any one man or any one school system. It has had a long history and many persons have assisted in its growth. In 1ts present form, however, it owes most to the group of educators and philosophers headed by Dowey, K1lpatrick, Childs, Bode, Collings, and Melvin.

In recent years, these philosophers have become popular teachers, have written numerous articles and books, have attracted 2 wide following, and have influenced oducational thought in all parts of the world. So wide-spread has boen this influence, that there are scarcely any purely formal schools. In some cases, only isolated bits of the activity plan have become effective but, In a few cases, whole systems have been transformed completely.

Our traditional system has neglected the development of the three-fold nature of the child, In the light of this position "education should be concerned with the release of emotional iffe and its co-ordination with the mental and psycho-physical functioning of the organism. 19 0ld habits, institutions, and fixed

19. Naumberg, Margaret, The Child and the Horld. p.271. 
traditions block potential power and energy, and personal conflict ensues. "The standards of education and society force back below the surface the most living and essential parts of our natures. We all learn to create a mask with which to front the world and cut ourselves off from that whole self which we might have been."20 It follows, then, that the school must be organized to prevent repression of the "subjective inner Iffe," organized to prevent tradition and fixed standards from acting as censors to repress desires. It is only through a liberation of this child's emotional iffe that the school can hope to develop ablifty to do independent thinking, power of original expression, a passionate enthusiasm for real work and "a satisfying synthesis of sustained effort and enthusiastic play." 21

The new school has placed its emphasis on self-expression and child interest. This emphasis hes stimulated new programs far from conventional types.

A comparison of the two procedures as the writer gathers from the literature is given below:

\section{Activity Program}

A. The child is the first consideration in an activity program. The personality of each child is respected. The curriculum is general,flexible, and suggestive. The teacher plans the work in a

\section{Traditional Program}

A. Iimited subject matter is the centre or point of departure when using the traditional procedure. Each subject is prescribed in more or less detall and the child is to be elted to the grade standard,

20. Ibid. p.311.

21. HIssong, Clyde. The Activity Movement. p.9. 
Activity Program

general way, spending most of her time and energy in acquainting herself with the possibilities of the situation, so that when she meets the children she will be sympathet1c with their point of view, open to suggestions from them, and rich in suggestions for their consideration. Education develops from within through an activity program. It connects up with the interests of the child and encourages the best that is in him, suggesting and guiding him.

B. During an activity program the school room is a busy place, physically as well as mentaliy. In much of the work the children take the initiative, moving about as their work demands. An activity program encourages the child to be active and creative.

C. Education through an activity program is said to bo natural. It tries to encourage the child to learn to IIve by living together in a more natural way, so that each child may be his own best self, growing in self-control and in consideration for others.

D. Education through an activity program is said to emphasize the present needs of the child-physical, mental, and spiritual.

E. An activity program claims to seek to encourage each child to make his individual contributions, evolving from what
Traditional Program

brought or kept up to the grade and passed on with the prescribed amount of information and of skili.

B. Through the traditional procedures education is Imposed upon the child from without. Having studied carefuliy the requirements of the course of study the teacher plans her lessons for weeks ahead. Then she is ready to assign definite lessons to be learned by the children.

C. The child is said to sit quietly at his desk, passively recelving what the teacher and the curriculum prescribes.

D. The atmosphere of the school room is presumably formal and artiflclal with the children under unnatural restraint - not their own natural selves.

E. It is said that in using the traditional procedure the child is being prepared for adult- 


\section{Activity Program}

he is into something better and thus doing his part in the evolution of society. Every child 1s born into an environment which is not static but is changing, and this is true resareing not only tho physical but also the social environment. It seems therefore desirable that children shall be trained not only in the best that the past and the present have to offer, but also in those habits of thinking and of action which will enable each one to make some individual contribution, however small, to society.

F. Through an activity program the children have experience with things and with people, - the other children, their parents, and friends. They talk about these experiences and use their own natural, childish (psychological) method of thinking.

G. Through an activity program the child is encoureged to observe, to compare, and to general1zo for himself, making his own definitions and rules and discovering for himself principles, and to test and apply these as his needs demand. This is the inductive (natural) method and makes for individual development.

H. The main question in the modern school of any grade is, "What is happening to each child, (Dick or Jane)? Is he growing as
Traditional Program

hood -. mainly by arills in spolling, resding, writing, and arithmetic, which everyone is expected at some time to need.

F. In the traditional procedure the child is to study and recite to the teacher the facts as found in prescribed school books. The traditional procedure attempts to train the child in accordence with the adult or logical mode of thinking.

G. The traditional procedure gives the child definftions, rules, and principles (generalization) to learn, to understand, and to apply; thus ho starts out with the generalization thought out by the text book maker or the teacher, and so works deductively.

H. The traditional procedure emphasizes drili. The first and second grade teacher asks herself at the end of a week. "How 


\section{Activity Program}

he ought to grow, phys1cally, mentally, and moraliy? Is he doing his best work? If not, why not?" In an activity program the main business consists in getting educative experlences, in thinking about them, and in forming and applying judgments; and the key to success is developing. ovolving, or growing.

I. Education through an activity program is knowledge which ha been ga ined through experlence and think Ing, know ledge which has become a part of the child and cannot be lost. It is that kind of knowledge which is power.

J. Education encouraging the pupil to observe, to compare, and to generalize for himself, to listen to the 1deas of others, to discuss freoly these 1dea, comparing them with his own, to look aga in and totcontinuelly and revise his generalizations in the light of further observation and discussions terds toward the foeling that things are not so fixed and settled as they seem, but rather that all is aifve, growing, evolving, and so to the habit of open-mindedness, consideration for the opinions and beliefs of others.

\section{Traditional Program}

many words have the children learned this wook? Do they read more smoothly? The ma in business of the traditional procedure consists of in the storing of facts and the acquiring of skill in the three R's, and the key to success is continuel repetition or DRIII.

I. The result of the traditional procedure is a mass of information with little meaning or relation to the present life needs of the child.

Jo The oducation furnishing one with static information, established rules, and principles, and training in the deductive mode of thinking: tends toward the feeling that all of these questions had been settled for all time, and so toward a closed mind. 
AIMS AND OBJECTIVES FOR AN ACTIVITY PROGRAM IN THE SECOND GRADE 


\section{AIMS AND OBJECTIVES FOR AN ACTIVITY PROGRAM IN THE SECOND GRADE}

The purpose of the second grade in terms of the activity program is to promote the all-round growth of the child: physical, mental, social, civic, moral, and emotional; and to provide for the proper relationship and integration of the various phases of growth. In order to meet such a problem of promoting and guiding child-growth, the first task of the educator is to provide a suitable and desirable setting or environment. This environment should be of such nature as to stimulate and bring forth desirable and worthwhile responses suitable to the age, ability, and previous development of the child. In such a school environment, the physical welfare of the child is of basic Importance. Proper bodily development and good physical health are foundations upon which the other elements of the educational program should be bullt.

"Instruction can wait,", says Professor Burnham, "but the demands of health are imperative ." Children should talk and move about freely. They should have a proper variety of work, with much activity and a minimum of direction. Children of the second grade should have a lelsurely day, serene, without strain or overstimulation. These far outweigh the usual health points stressed, important as they are - such points as correct posture, absence of eyestrain, establishment of health habits, and vigilant watch for illness. 
The environment of the child should be examined as carefully from the viewpoint of promoting mental health and well-being, as of promoting such element: upon the physical side.

Children of the second grade should be happy, successful, confident; should feel that they are making progress, without fear of worry, or a sense of inferiority. Chlldren should find joy and satisfaction in their work, what DeCroly calls "the hablt of working foyfully and collectively :" They should have suitable outlets for their energy, instead of being physically, mentally, and socially repressed. They should pass their days with ilttie friction, have a life of fun and enjoyment. Physical and mental health are basal criteria in the modern school.

Another important objective for the second grade is to promote social adjustment. Young children coming to school leave the smaller social group of the family for the larger group of the school. They must learn to be socialiy adjusted to others in this larger group, to Iive together harmonlously, to cooperate; in general to be acceptable to the group, not only by positive means, but by checking such unpopular traits as being rough, Inconsiderate, selfish, loud-voiced, or "mean ." They must learn to use liberty and to respect authority; to be helpful and dependable; to lead, to follow, and to participate (share) in varied activities with which they are associated. 
In the social, civic, moral, and emotional flelds, there should be provided ample opportunity for the proper and normal development of each child. In the work of the school, there should be much opportunity for the development of the abilities to lead and to follow, to plan and to execute, to act and to judge. Many people think that these are the functions of the teacher, but they are not as seen in the activity program. A teacher, it has been well said, "must learn to be a member of a stock company, and not the star performer:?

Children should have a chance to explore, to investigate, to make things happen, to satisfy their curiosity. They should have a chance to express themselves, not only through social intercourse and free conversation, creative writing and art, and through carrying out their own purpose, but also through materials, so that by experimenting with materlals freely, they may have a rich perceptual experience upon which to build. The experiences, problems, and materials should lead naturally to further activity on ever higher levels.

Closely allied to all of this is the need of treating each child as an individual -- to abolish mass education and the lock step. This means that we cannot tolerate rows of screwed-down desks and chairs, with a statue-like little child at each one, the teacher always

1. Stevens, Marion Paine. The Activities Curriculum in the Primary Gradea. p.ll. 
active, the children only occasionally so, and then only when the teacher permits it and directs their activity. The activity program insists that children advance at their own pace, whether slow, moderate or rapld, instead of at the pace of a mythical "average child" who does not and never did exist. It means that children's individual purposes and cholces are important, at least as important as the teacher's purposes and cholces, and that it is their right to be encouraged and helped in carrying them out.

According to the activity program it is also necessary to develop certain skills and techniques. The following are three principal groups:

1. The tools of learning which children need, often called the School Arts - reading, writing, spelling, and arithmetic.

2. The motor skills, mainly use of those tools which are an extension of the hand - paint brush, crayon, pencil, and the sewing, cutting, and measuring tools - all of them far earlier in history of civilization than the traditional academic skills, and socis.liy moro important for children.

3. Improved oral expression, developed as children talk naturally in their free communication of ideas, and as we who teach them watch for and correct unpleasant volces, slovenly speech, and errors of pronfunciation. 
once occur to any teacher. If the activities in the second grade are a natural and constructive outcome of everyday child Iife in terms of the activity program, there will be a "felt" need on the part of the children for mastery in the tool subjects. This subject matter becomes a conscious means of carrying on present activities and of rebullaing experiences on higher levels. There will also be a natural need for drilling In fundamentals in such a situation.

Last but not least, it is necessary to establish certain habits and attitudes. In addition to physical habits, there are the social moral habits of promptness, orderliness, obedience, self-control (a great saver of time and energy), perseverance, truthtell1ng, keeping a promise, economy in using materials, good manners (often called "minor morals"), reliability, taking responsibility, and seeing things through - in general higher behavior standards. There are also intellectual habits. Examples are: associating the common things in our environment (as trees, a wood-pile, furniture, and child's own work with tools have a common bas1s); fair-mindedness; analyzing; judging standards of work. All such social-moral and intellectual habits are specific, not general, and must be closely assoclated with the situations in which they are to be practiced. Only so do children get the WILI as well as the CAN and the SEE of conduct, so that they want to do and remember to do what they have learned. 
Attitudes are more general than habits. They have been called "habits with feeling added ." The formation of health attitudes toward life, and a constantiy increasing capacity for appreclating beauty, fineness, and high things, are the real fundamentals which a child is to carry away from his years at school. In conclusion it would be well to state definitely the aims of an activity program in the second grade:

1. To protect and develop health.

2. To safeguard mental health.

3. To promote social adjustment.

4. Provide for growth and development.

5. To treat each child as an individual.

6. Supply ideas and occupations suitablo for children's leisure.

7. Develop certain skills and techniques.

8. Establish attitudes of appreciation of Iife, of beauty, and fineness. 
AN EXPERIMENTAL EVALUATION OF TWO METHODS

OF TEACHING AT THE SECOND GRADE LEVEL - THE ACTIVITY PROGRAM VERSUS TRADITIONAL TEXTBOOK PROCEDURES 
CHAPTER IV

AN EXPERTMENTAL EVALUATION OF TTO METHODS OF TEACHING AT THE SECOND GRADE LEVEL - THE ACTIVITY PROGRAM VERSUS TRADITIONAL TEXTBOOK PROCEDURES

Problem: To determine the effects of instruction of second grade children taught by the activity program and by traditional textbook methods.

Materials: Forty children of the Longfellow School of the Loulsville Public School System. Two classes were selected for the experiment. The 1A-2B Class of February, 1937, through June 1937, was taught by the activity program. The IA-2B Class of September, 1937, through January, 1938, was taught by the traditional textbook method. Both of these classes were taught by the same teacher.

Procedure: The first weok of the semester beginning Fobruary 22, 1937, the 1A-2B Class was tested with the following:

1. Metropolitan Achievement Test. Primary II Battery: Form A.

2. The Vineland Soctal Maturity Scale by Doll.

3. Personality Inventory for children by Brown.

Scores of children used in the experiment are given in Table XXXIV. During this first week the teacher of this class (the writer), basing her judgments on her own observations and opinions of the previous teacher of these children, rated them on the following: 
1. Cooperation. Willingness children showed to work with one another.

2. Initiative. Power of doing or starting activitios without being told to do them.

3. Interest. Being concerned, attentive, and desiring to carry on the activities of the class.

4. Pupil participation. Effort children put forth in taking part in all activities.

5. Pupli opinion. How easily and frequently children expressed their own oplinions.

A rating scale of $A, B, C, D$, and $E^{l}$ was used. The teacher also rated these chlldren for scholarship using a scale of 1,2 , and $3^{2}$. The data for these ratings may be found in Table XXXIV. During the semester these children were given objective tests on the nits of the activity program followed (see Appendix "A"). The Ilbrary, The Dry Goods Store, and The Post Offlce. The tests were made by the teacher. Coples of them are given on pp. 118/125, 146/153 and 170/177. Scores and data as to reliability are given in Table XXIX.

Group I was taught by the activity program for sixteen weeks. During this time different phases of the communty were studieds The Library, The Dry Goods Store, and The Post office. Trips to these places were taken by the class. The construction of each unit was carried on and operated by the children based on their

1. Evaluation of Rating Scale. A=Excellent. B=Very Good. C=Good. $D=$ Fa1 1 . E=PoOr.

2. Evaluation of Rating Scale. IFAbove Average. 2EAverage. 3-Below Avंe rage. 
observations of the Library, Dry Goods Store, and Post Office. The study of The Library and The Post office took six weeks each and The Dry Goods Store took four weeks. Detalled descriptions of these units are given on pp. $87 / 180$ inclusive.

At the end of the semester, June,1937, Group I was retested using Form B of the Metropolitan Achievement Test, the Vineland Social Maturity Scale, and Personality Inventory for Children. The teacher again rated the children for cooperation, initiative, interest, pupil participation, and pupil oplnion, using the same scale as at the beginning of the semster. The children were also rated for scholarship using the 1, 2, 3 scale as mentioned above. These data are given in Table XXXIV.

The flrst week of the semester beginning September 13, 1937, the same testing and rating procedures as was used the preceding semester were employed with the new $1 \mathrm{~A}-2 \mathrm{~B}$ Class which will be referred to as Group II. All data for these children are given in Table XXXIV.

Group II was taught for sixteen weeks by the traditional textbook method. These children were not taken on any trips and they did not participate in any activities of the type employed with Group I. Group II was taught by using the adopted textbooks and 
following the assignments and directions of the teacher from day to day. Much time was given to drill on all subject matter. A detailed description of these procedures is given on pp. 181/194 inclusive. The group of children studied the various phases of the communty (The Library, The Dry Goods Store, The Post Office) by reading stories from the books provided by the teacher.

At the end of the semester, January, 1938, Group II was retested using the same tests as were given Group I in June, 1937, and was rated by the teacher as at the beginning of the semester. The data are given in Table XXXIV.

The children in Group I and Group II were paired by using the initial test data and ratings given in Table XXXIV. Pairings are in terms of chronological age, mental age, reading, arithmetic, language, spelling, soclal maturity, personality development, cooperation, Initiative, interest, pupil participation, and pupli opinion. Every effort was. made to get two groups as nearly comparable as possible prior to being instructed by widely different methods. Group I composed of twenty children was taught by the activity program procedures, and Group II composed of twenty children, each child paired with a child in Group I, was taught the same number of days by the traditional textbook method. How well these groups compared so far as the avallable data are concerned 
Is shown in Table XXX. Detailed explanations of the data, methods of pairing, interpretations, and conclusions are given on pp. $34 / 86$ inclusive of this thesis. Detalled outlines of the teaching procedures followed by the two methods are given in Appendices " $A$ " and "B :" It should be noted that the forty children comprising the two experimental groups were taken from a total of sixty children - thirty per semester. Data for only twenty children from each semester were used since absence from school, lack of test data, or widely divergent inftial test scores eliminated about one third of the children from consideration. In other words, data are considered only for those children who attended school each day of the semester and whose tests and observational data (ratings) could be paired satisfactorily with those of children in the other group.

Data: The experimental data are given under threo headings:

1. Intellectual Factors - those common sk11ls and subject matter learnings in which mastery is universaliy required of second grade chlldren. This solid nucleus of obvious learnings include verbal intelligence, achlevement in reading, arithmetic, language usage, and spelling.

2. Dynamic Factors - social development 
and personality adjustment.

3. Performance Factors - varlous aspects of behavior such as cooperation of children with other children as well as with the teacher, initiative used In attacking new problems, pupil participation, pupil opinion, and interest shown in all work and activities. Initial group data, 1.e., data secured during the first week, are given in Tables I to XIV inclusive. It will be remembered that the groups were paired on the basis of these data.

Comparability of the two experimental groups may be judged from the means, standard deviations, and critical ratios. Means were calculated by the regular procedures. Standard deviations were determined from the formula, $\sigma={\sqrt{\frac{\sum x_{i}^{2}}{N}-C^{2}}}^{1}$ Standard deviations of means were calculated from the formula $\sigma_{M}=v_{N-1}{ }^{2}$, and standard deviations of differences between means were

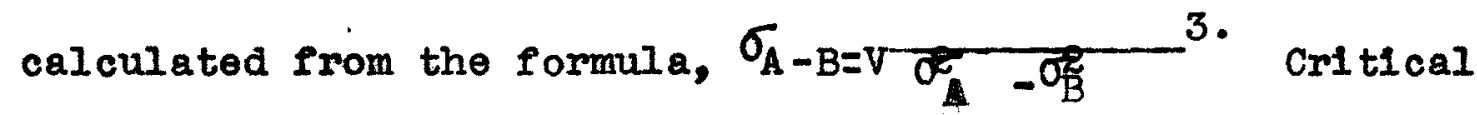
ratios are quotients of differences between means divided by the standard deviations of these differences. A difference is considered significant, statistically if the critical ratio is 3.00 or more - the accepted procedure in interpretation of educational data. Throughout the discussion Group I refers to those children taught by the activity program and Group II to those taught by the

1. Dunlap, J.W. and Kurtz, A.L. Handbook of Statist1cal Nomographs, Tables and Formulas. Yonkers-on-Fudson, WorId Company. I932. Fo rmula $3 \%$ 2. Ibid. - Formula 8.

3. IbId. - Formula 154. 
traditional textbook method. This is indicated in Table I and omitted thereafter.

TABLE I

LIFE AGES, OF TWO GROUPS OF SECOND GRADE CHILDREN AT BEGINNING OF EXP ERIMENTAL PERIODS

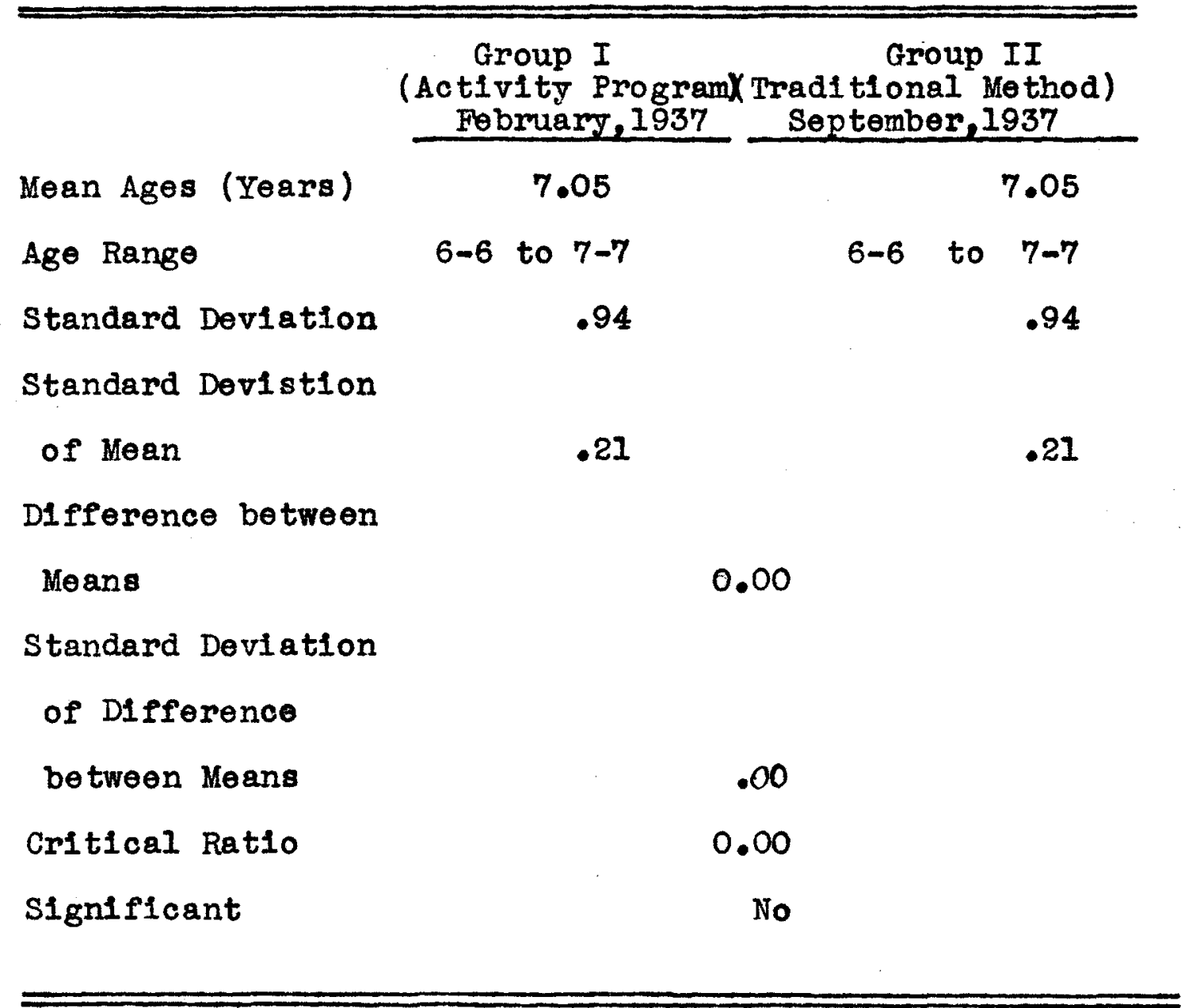

These data show that there is no statistical difference between the mean life ages of the groups. 


\section{$\underline{\text { TABLE }} I I$}

INTELIIGENCE QUOTIENTS* OF TNO GROUPS OF SECOND GRADE CHILDREN AT BEGINNING OF EXPERIMENTAL PERIOD

\begin{tabular}{|c|c|c|c|c|}
\hline \multirow{3}{*}{$\begin{array}{l}\text { Mean Quotients } \\
\text { Range }\end{array}$} & \multirow{2}{*}{\multicolumn{2}{|c|}{$\begin{array}{c}\text { Group } I \\
\text { February, } \\
1236 \\
122.25\end{array}$}} & \multicolumn{2}{|c|}{$\begin{array}{c}\text { Group II } \\
\text { September, } 1936\end{array}$} \\
\hline & & & & 119.35 \\
\hline & 94 to & 140 & 96 to & 139 \\
\hline Standard Deviation & & 12.4 & & 12.3 \\
\hline Standard Deviation & & & & . \\
\hline of Means & & 2.83 & & 2.82 \\
\hline \multicolumn{5}{|l|}{ Difference between } \\
\hline Means & & & 2.90 & \\
\hline \multicolumn{5}{|l|}{ Standard Deviation } \\
\hline \multicolumn{5}{|c|}{ of Difference between } \\
\hline Means & & & 3.99 & \\
\hline Critical Ratio & & & .73 & \\
\hline Significant & & & No & \\
\hline
\end{tabular}

These data show that the mean intelligence quotients of the children in the two experimental groups are not significantly different.

*Engle, Anna M., Detro1t First Grade Intelligence Test, Eorm A. Yonkers-on-Hudson, WorId Book Company, I92I. 
Intellectual Fotors:

\section{TABLE III}

ACHIEVEMENT AGES* OF TWO GROUPS OF SECOND GRADE CHILDREN AT BEGINNING OF EXPERIMENTAL PERIOD

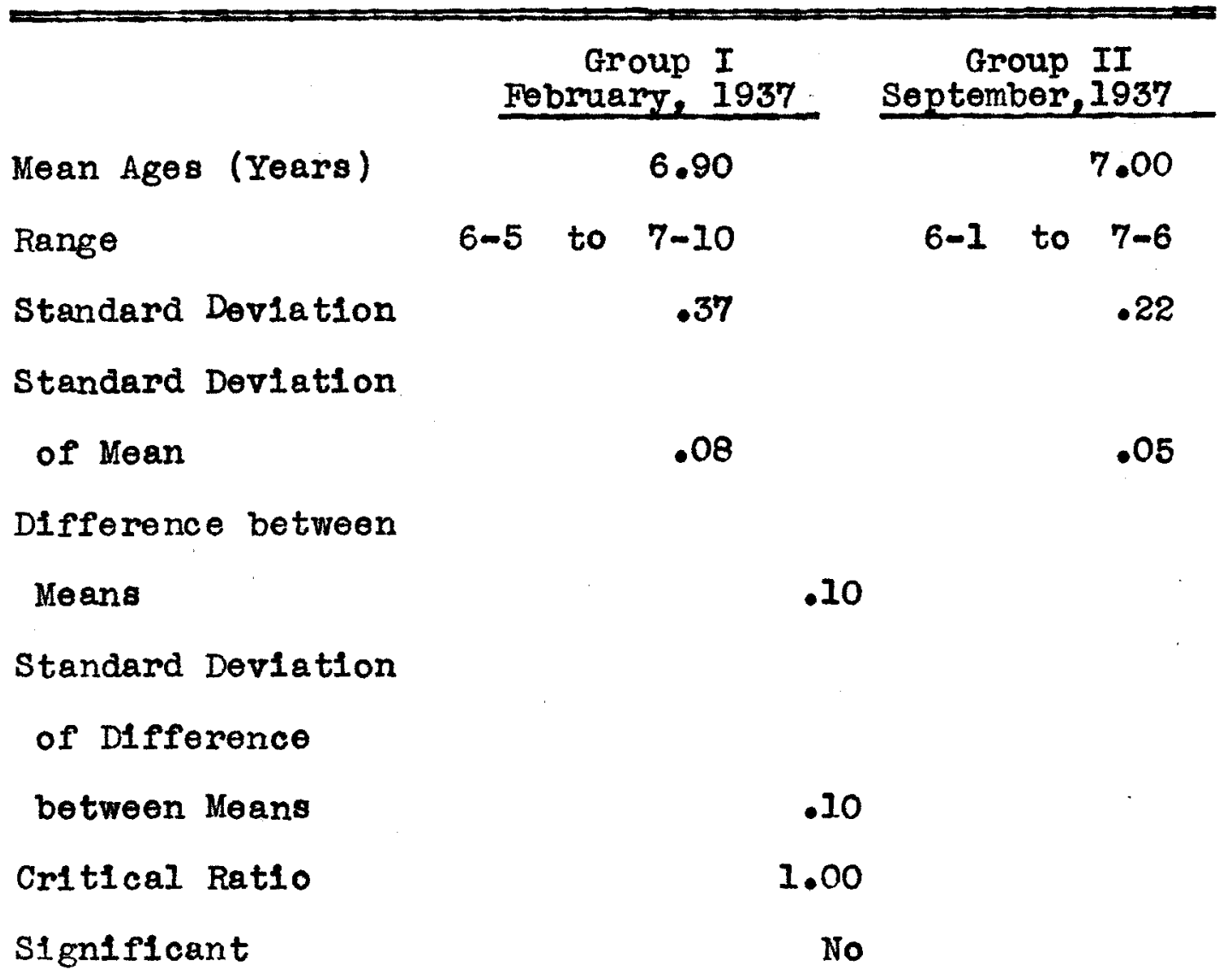

These data show that the mean achievement ages of the children in the experimental groups are slightly, but not significantly different.

* Hildreth, Gertrude H., Metropolitan Achievement Tests Primary II Battery: Form A. Yonkers-on-Fudson, WorId Book Company, 1933. 
TABLE IV

READING SCORES* OF TWO GROUPS OF SECOND GRADE CHILDREN AT BEGINNING OF EXPERIMENTAL PERIOD

\begin{tabular}{|c|c|c|c|c|}
\hline \multirow[b]{2}{*}{ Mean Scores } & \multicolumn{2}{|c|}{$\begin{array}{c}\text { Group } I_{197} \\
\text { Fobruary, } 1937\end{array}$} & \multicolumn{2}{|c|}{$\begin{array}{c}\text { Group II } \\
\text { September, } 1937\end{array}$} \\
\hline & \multicolumn{2}{|r|}{7.10} & \multicolumn{2}{|r|}{9.70} \\
\hline Range & 2 & to 16 & 2 & to 25 \\
\hline Standard Doviation & & 3.82 & & 6.26 \\
\hline \multicolumn{5}{|l|}{ Standard Deviation } \\
\hline of Mean & \multicolumn{2}{|r|}{.88} & \multicolumn{2}{|r|}{1.44} \\
\hline \multicolumn{5}{|l|}{ Difference between } \\
\hline Means & \multicolumn{4}{|c|}{2.60} \\
\hline \multicolumn{5}{|l|}{ Standard Doviation } \\
\hline \multicolumn{5}{|l|}{ of Difference } \\
\hline between Means & \multicolumn{4}{|c|}{1.68} \\
\hline Critical Ratio & \multicolumn{4}{|c|}{1.54} \\
\hline Signiflcant & \multicolumn{4}{|c|}{ No } \\
\hline
\end{tabular}

These data show that the mean reading scores of the children in the experimental groups are slightly, but not signigicantly different.

* Hildreth, Gertrude H., Metropolitan Achievement Tests Primary II Battery: Form A. Yonkers-on-Fudson, worId Book Company, I933. Test 1,2 , and 3 . 


\section{TABLE}

ARI THMETIC SCORES* OF TWO GROUPS OF SECOND GRADE CHILDREN AT BEGINNING OF EXPERIMENTAL PERIOD

\begin{tabular}{|c|c|c|c|c|}
\hline & Fobru & $\begin{array}{l}\text { Group I } \\
\text { ary, } 1937\end{array}$ & $\begin{array}{r}G r \\
\text { Septer } \\
\end{array}$ & $\begin{array}{l}\text { oup II } \\
\text { ber, } 1937\end{array}$ \\
\hline Mean Scores & & 8.75 & & 12.70 \\
\hline Range & 3 & to 20 & & to 22 \\
\hline Standard Deviation & & 3.83 & & 4.42 \\
\hline \multicolumn{5}{|l|}{ Standard Deviation } \\
\hline of Mean & & .88 & & 1.01 \\
\hline \multicolumn{5}{|l|}{ Difference between } \\
\hline Means & \multicolumn{4}{|c|}{3.90} \\
\hline \multirow{2}{*}{\multicolumn{5}{|c|}{$\begin{array}{l}\text { Standard Deviation } \\
\text { of Difference }\end{array}$}} \\
\hline & & & & \\
\hline between Means & \multicolumn{4}{|c|}{1.34} \\
\hline Critical Ratio & \multicolumn{4}{|c|}{2.91} \\
\hline Significant & \multicolumn{4}{|c|}{ Probably } \\
\hline
\end{tabular}

These data Indicate that according to the arithmetic ability of the children in both experimental groups there is probably a significant difference. The children in Group II were more advanced in arithmetic than the ohildren in Group I.

* Hildreth, Gertrude H.,Metropolitan Achievement Testo Primary II Battery: Form A. Yonkers-on-Hudson, Wo rId Book Company, I933. Tests 4 and 5 . 
LANGUAGE USAGE* SCORES OF TWO GROUPS OF SECOND GRADE CHILDREN AT BEGINNING OF EXPERTMENTAL PERIOD

\begin{tabular}{lccc}
\hline & $\begin{array}{c}\text { Group I } \\
\text { February } 1937\end{array}$ & \multicolumn{1}{c}{$\begin{array}{c}\text { Group II } \\
\text { September, } 1937\end{array}$} \\
\cline { 2 - 3 } Mean Scores & 1.90 & & 1.80 \\
Range & 0 to 5 & & to 5 \\
Standard Deviation & 1.04 & & .99 \\
Standard Deviation & & & .22 \\
of Mean & .24 & & \\
Difference between & & & \\
Means & & .10 & \\
Standard Deviation & & & \\
of Difference & & & \\
between Means & & .32 & \\
Critical Ratio & & .31 & \\
Significant & & No
\end{tabular}

These data indicate that in language ability both experimental groups are comparable.

* Hildreth, Gertmide H., Metropolitan Achievement Tests Primary II Battery: Form A. Yonkers-on-Hudson, World Book Company, I933. T'est 6. 
SPELLING SCORES* OF TWO GROUPS OF SECOND GRADE CHILDREN AT BEGINNING OF EXPERIMENTAL PERIOD

\begin{tabular}{|c|c|c|}
\hline & $\begin{array}{c}\text { Group I } \\
\text { Febmuary, I937 }\end{array}$ & $\begin{array}{c}\text { Group II } \\
\text { Setpember, } 1937 \\
\end{array}$ \\
\hline Mean Scores & 4.75 & 2.15 \\
\hline Range & 2 to 7 & 0 to 8 \\
\hline Standard Deviation & 1.37 & 1.98 \\
\hline $\begin{array}{l}\text { Standard Deviation } \\
\text { of Mean }\end{array}$ & .31 & .45 \\
\hline Difference between & & \\
\hline Means & & 2.60 \\
\hline $\begin{array}{l}\text { Standard Deviation } \\
\text { of Difference }\end{array}$ & & \\
\hline between Mean & & .55 \\
\hline Critical Ratio & & 4.35 \\
\hline Significant & & Yes \\
\hline
\end{tabular}

These data show that the chlldren in Group I working under the activity program were, on the average, much in advance of those in Group II working by the traditional textbook method at the beginning of the experimental periods.

* Hildreth, Gertrude H., Metropolitan Achlevement Tests Primary II Battery: Form A. Yonkerson-Nudson, WorId Book Company, I933. Test 7 . 
Dynamic Factors:

TABLE VIII

SOCIAL פJOTIENTS* OF TWO GROUPS OF SECOND GRADE CHILDREN AT BEGINNING OF EXPERIMENTAL PERIOD

\begin{tabular}{lcc}
\hline & $\begin{array}{c}\text { Group } I \\
\text { February, } 1937\end{array}$ & $\begin{array}{c}\text { Group II } \\
\text { September, } 1937\end{array}$ \\
\cline { 2 - 2 } Mean Quotients & 126.40 & 112.10 \\
Range & 106 to 155 & 100 to 120 \\
Standard Deviation & 12.65 & 6.81 \\
Standard Deviation & & \\
of Mean & 2.89 & 1.56 \\
Difference between & & \\
Mean & & 14.30 \\
Standard Deviation & & \\
of Difference & & \\
between Means & 3.28 \\
Critical Ratio & 4.35 \\
Significant & Yes \\
\hline \hline
\end{tabular}

The Vineland Social Maturity Scale provides a definite outline of detalled performances in respect to which children show a progressive capacity for looking after themselves and for participating in those activities which lead toward ultimate independence as adults. These data show that the mean social quatients of the * Doll, Edgar A., The VIneland Social Maturlty Scale, New Jersey. The Training school At Vineland, New Jersey, 1936. 
children in the two experimental groups are

significantly different. The children in Group I working under the activity program were, on the average, more mature socially than those in Group II working by the traditional textbook method at the beginning of the experimental period.

\section{TABLE IX}

PERSONALITY RATINGS* OF TWO GROUPS OF SECOND GRADE

CHIIDREN AT BEGINNING OF EX PERIMENTAL PERIOD

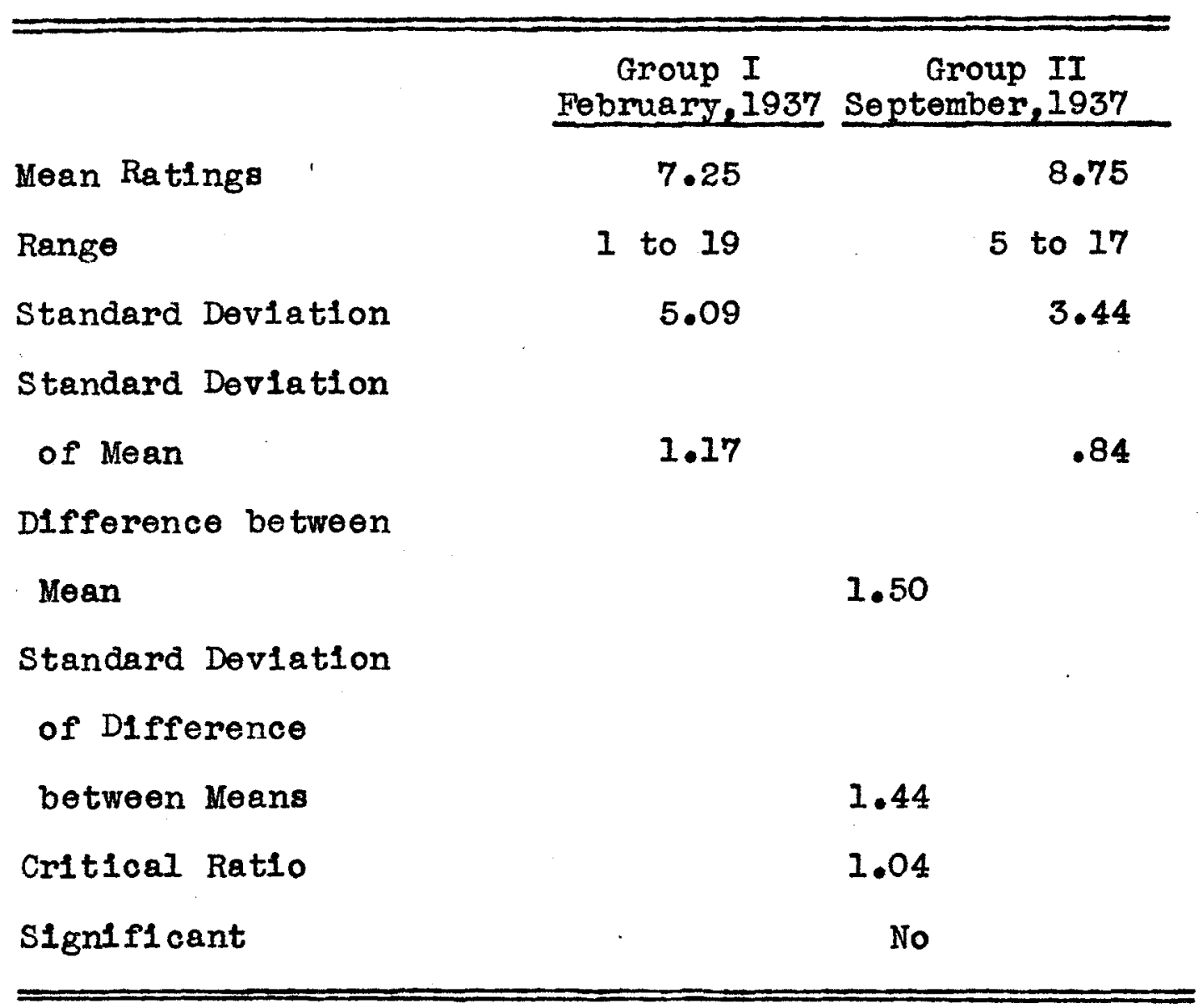

The Personality Inventory for Children by Fred Brown

* Brown, Fred, Personallty Inventory for Children. New York. The Psychological Corporation, 1935. 
consists of eighty questions regarding a child's personality. These questions were answered by checking yes or no for each question. The fewer questions marked yes indicated the better personality. These data show that the mean personality ratings of the children in the experimental groups are slightly, but not significantly different.

Performance Factors:

TABLE $\underline{X}$ COOPERATION RATINGS* OF TNO GROUPS OF SECOND GRADE CHILDREN AT BEGINNING OF EXPERIMENTAL PERIOD

\begin{tabular}{lcr}
\hline & $\begin{array}{c}\text { Group I } \\
\text { Februar, 1937 }\end{array}$ & $\begin{array}{c}\text { Group II } \\
\text { September, 1937 }\end{array}$ \\
\cline { 2 - 3 } Mean Ratings & 1.50 & 1.40 \\
Range & 0 to 2 & to 2 \\
Standard Deviation & .59 & .63 \\
Standard Deviation & & .14 \\
of Mean & .13 & \\
Difference between & & \\
Means & & \\
Standard Deviation & & \\
of Difference & & \\
between Means & .66 \\
Critical Ratio & No \\
Significant & & \\
\hline
\end{tabular}

These data show that the mean cooperation ratings of * Cooperation - Willingness children showed to work with one another as well as with teacher. These ratings were secured from the writer's observations during first week of experiment. Rating scale given on p.73. 
the children in the experimental groups are not

signiflcantly different.

TABLE XI

INITIATIVE RATINGS* OF TWO GROUPS OF SECOND GRADE CHILDREN AT BEGINNING OF EXPERIMENTAL PERIOD

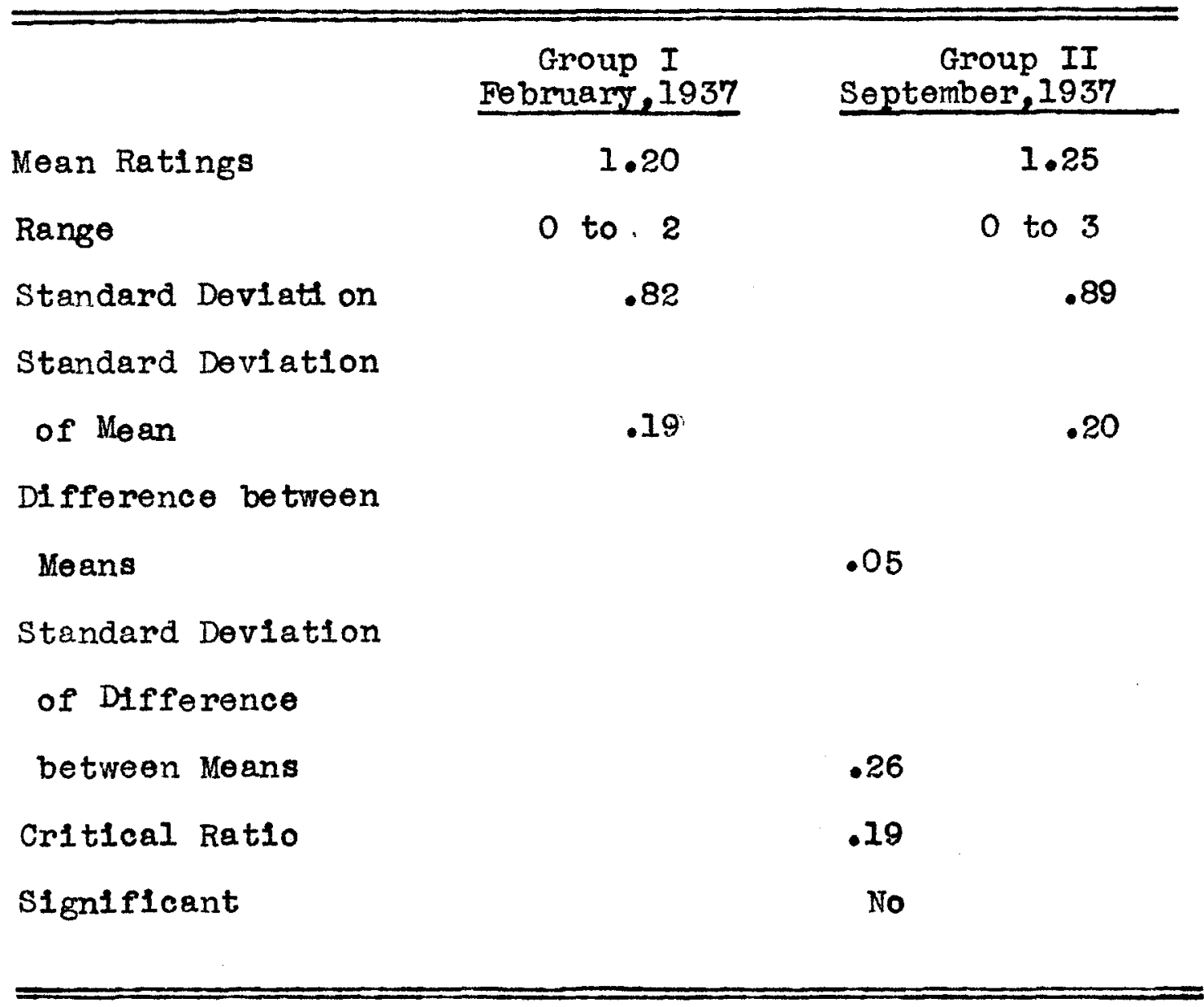

These data show that the mean inftiative ratings of the children in the experimental groups are not significantly different.

* Initiative - Power of doing or starting activities without being told to do them. These ratings were secured from the writer's observations during first week of experiment. Rating scale given on $\mathrm{p} .73$. 
TABLE XII

PUPIL PARTICIPATION RATINGS* OF TWO GROUPS OF SECOND GRADE CHIIDREN AT BEGINNING OF EXPERIMENTAL PERIOD

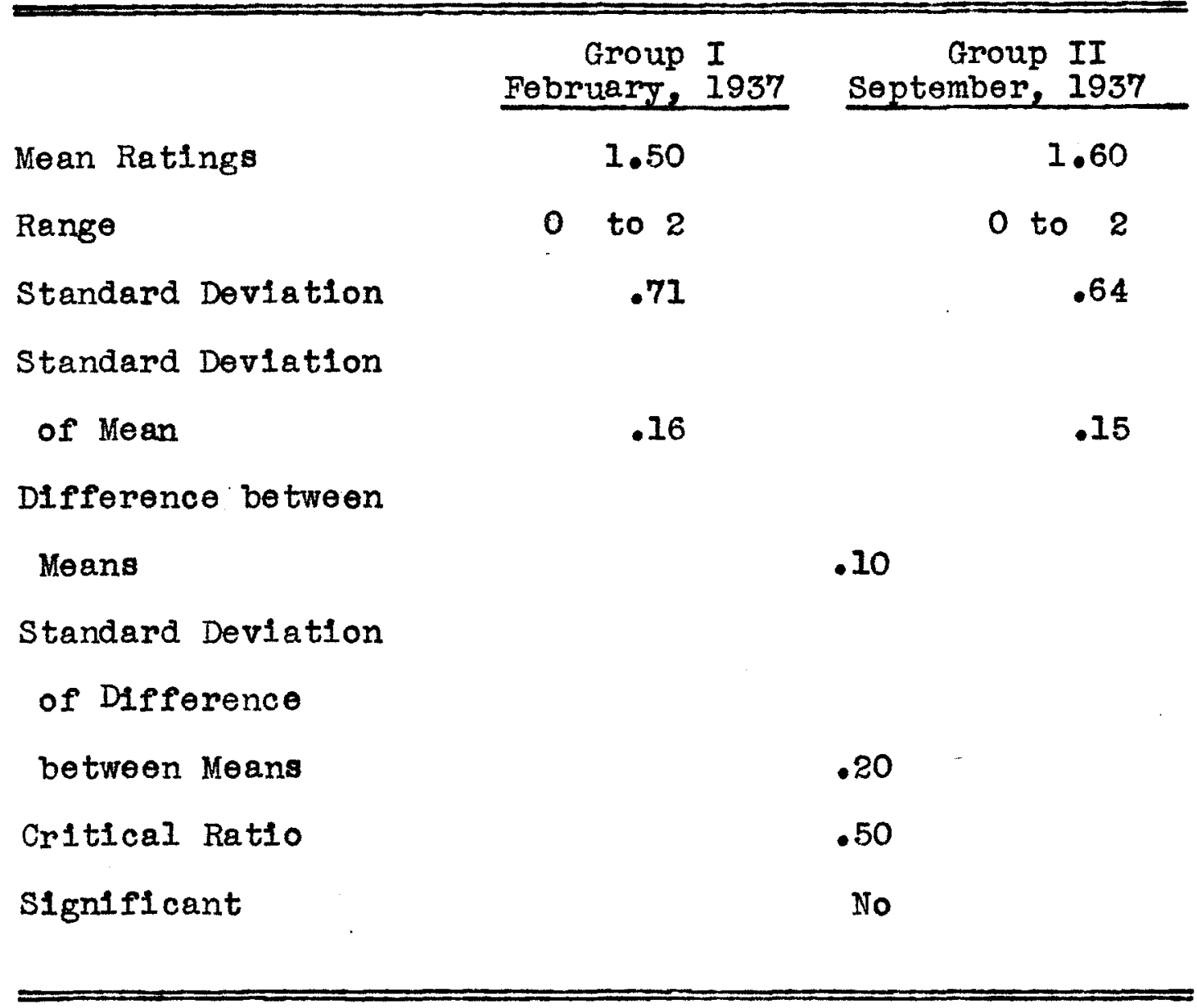

These data show that the mean ratings for pupil participation of the children in the experimental groups are not significantly different.

* Pup1l Participation - Effort children put forth in taking part in all activities. These ratings were secured from the writer's observations during first week of experiment. Ratins scale given on p.73. 


\section{TABLE XIII}

PUPIL OPINION RATINGS* OF TYO GROUPS OF SECOND GRADE CHILDREN AT BEGINNING OF EXPERIMENTAL PERIOD

\begin{tabular}{lcc}
\hline & $\begin{array}{c}\text { Group I } \\
\text { February, 1937 }\end{array}$ & $\begin{array}{c}\text { Group II } \\
\text { September, I937 }\end{array}$ \\
\cline { 2 - 3 } Mean Ratings & 1.60 & 1.60 \\
Range & 0 to 3 & 0 to 3 \\
Standard Deviation & .67 & .67 \\
Standard Deviation & & .15 \\
of Mean & .15 & \\
Difference between & & .00 \\
Means & & \\
Standard Deviation & \\
of Difference & .00 \\
between Means & No \\
Critical Ratio & \\
Significant & \\
\hline
\end{tabular}

These data show that there is no significant difference between the mean ratings for pupil opinion of the two experimental groups.

* Pupil opinion - How easily and frequently children expressed their own opinions. These ratings were secured from the writer's observations during first week of experiment. Rating scale given on p.73. 


\section{TABLE XIV}

INTEREST RATINGS* OF TWO GROUPS OF SECOND GRADE CHILDREN AT BEGINNING OF EXPERIMENTAL PERIOD

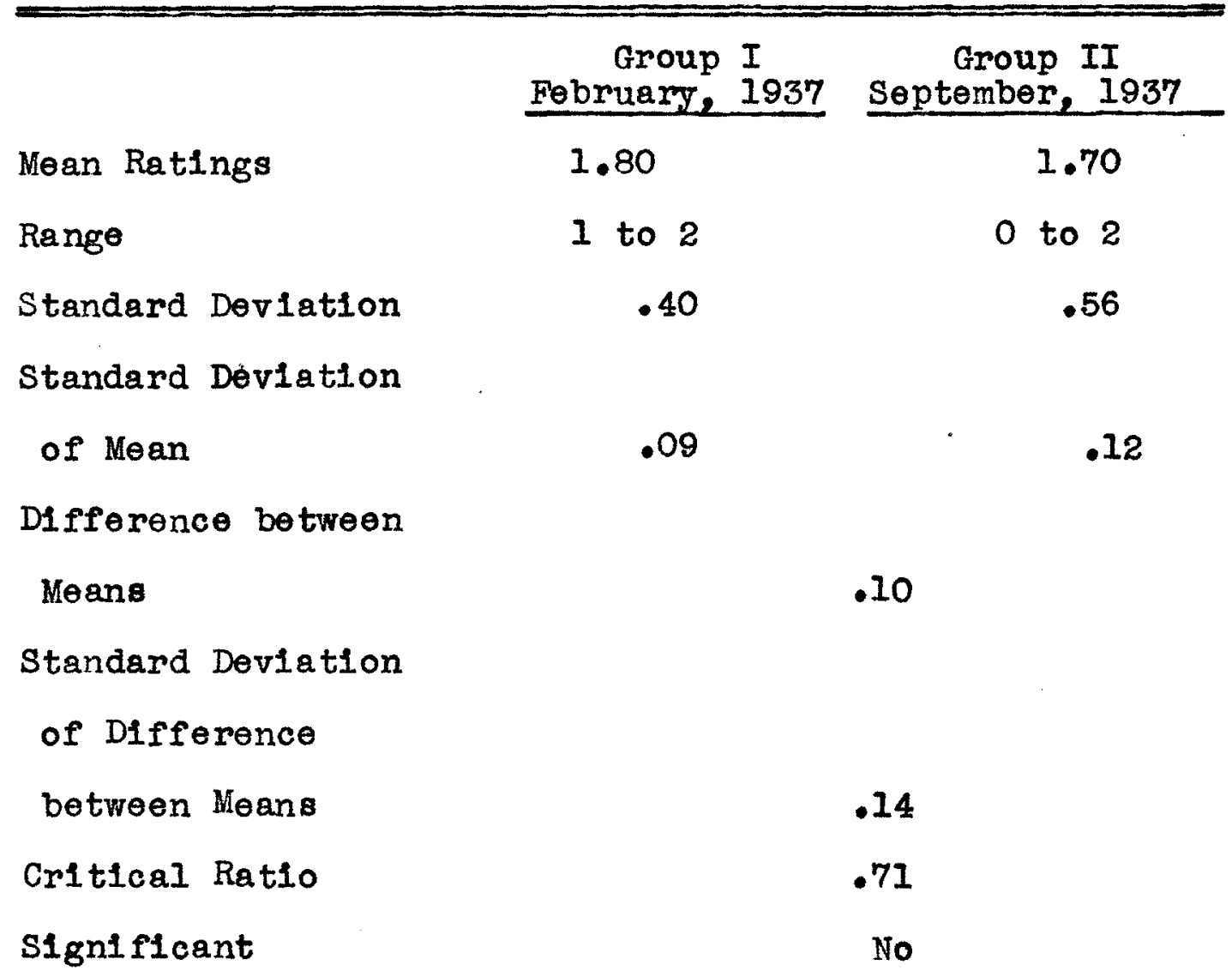

These data show that the mean interest ratings of the children in the experimental groups are not significantly different.

* Interest - Being concerned, attentive, and desiring to carry on activities of the class. These ratings were secured from the writer's observations during first weok of experiment. Rating scale given on p.73. 
TEACHER RATINGS ON SCHOLARSHIP OF TWO GROUPS OF SECOND GRADE CHILDREN AT BEGINNING OF EXPERIMENTAL PERIOD

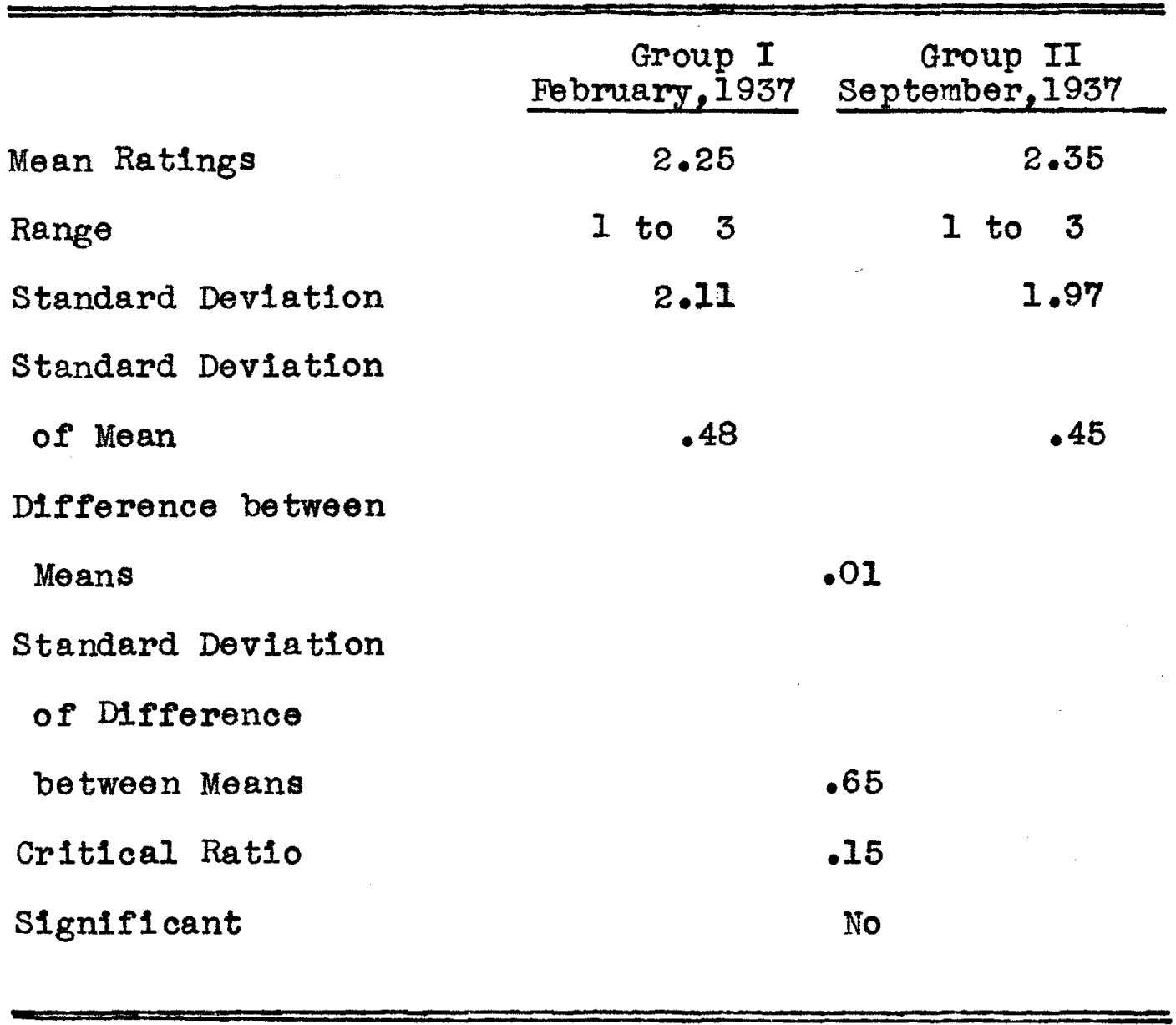

These data indicate that according to the teacher ratings of both groups they are comparable. There is a slight difference between means, but it is not significant. 
Final group data, 1.e., data secured during the last week of the experiment are given in Tables XVI to XXVIII inclusive. The progress made by the two experimental groups may be judged from the means, standard deviations, and critical ratios. The formulas for these are given on page 35. A difference is considered significant, statistically if the critical ratio is 3.00 or more - the accepted procedure in interpretation of educational data. The following tables give the results of the final data for both groups. In these tables one can seo the progress made by each group. The data are treated exactiy as for the infial data. 
ACHIEVEMENT AGES* OF TWO GROUPS OF SECOND GRADE CHILDREN AT END OF EXPERIMENTAL PERIOD

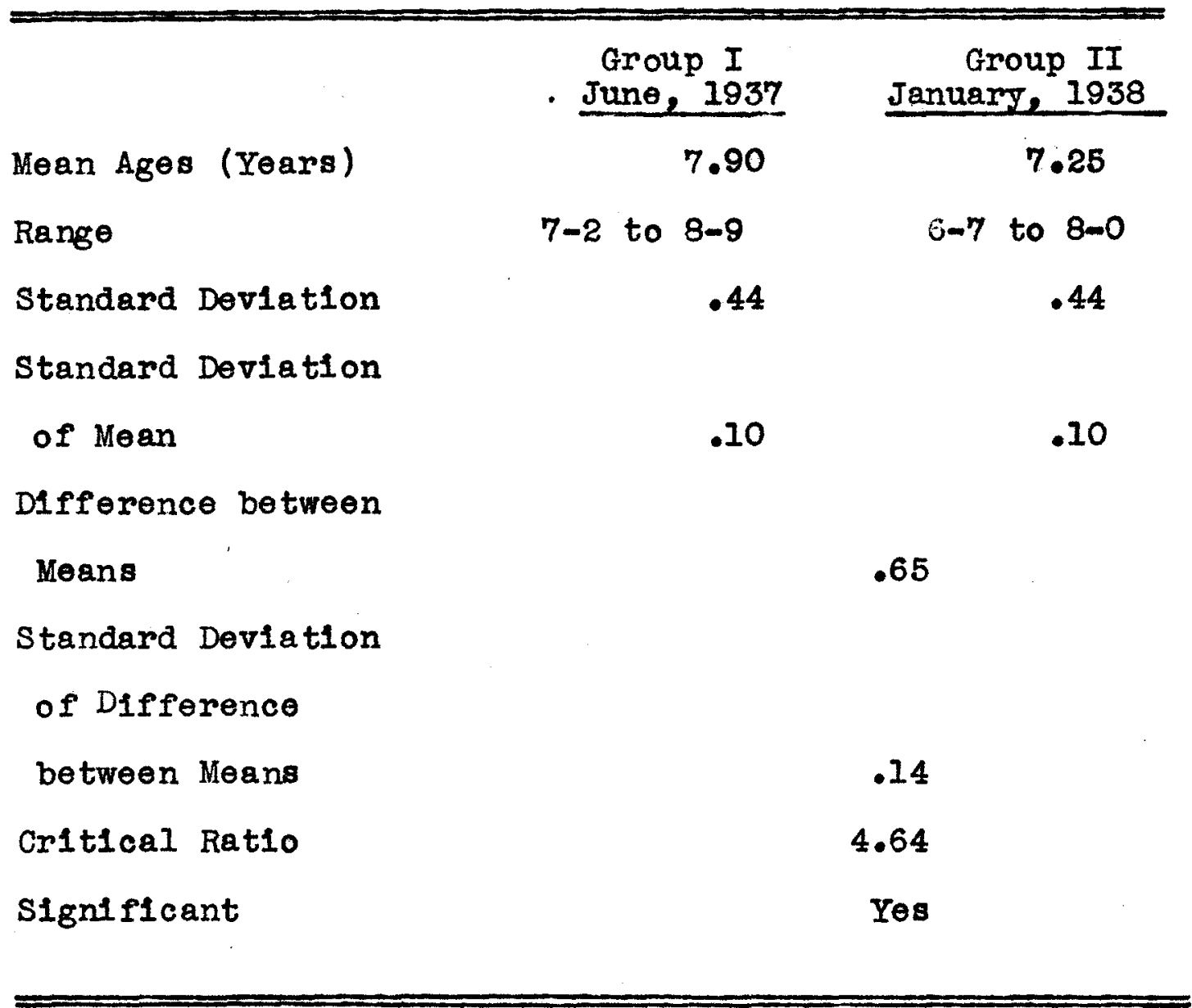

These data indicate that in all the academic skills measured the children working under the activity program are superior to the children working by the textbook method. The achlevement ages at the close of the experimental period show that there is a significant difference.

* Hildreth, Gertrude H., Metropol1tan Achievement Tests Primary II Battery: Form B. Yonkers-on-Hudson, WorId Book Company, I933. 


\section{TABLE XVII}

READING SCORES* OF TWO GROUPS OF SECOND GRADE CHILDREN AT END OF EXPERIMENTAL PERIOD

\begin{tabular}{lcc}
\hline & $\begin{array}{c}\text { Group I } \\
\text { June, 1937 }\end{array}$ & \begin{tabular}{c} 
Group II \\
\cline { 2 - 3 } Manuary, 1938
\end{tabular} \\
\cline { 2 - 3 } Range & 26.95 & 14.60 \\
Standard Deviation & 11 to 42 & 3 to 38 \\
Standard Deviation & 8.35 & 12.16 \\
of Mean & 1.91 &
\end{tabular}

Difference between

Means

12.35

Standard Deviation

of Difference

between Means

3.38

Critical Ratio

3.65

Signiflcant

Yes

These data show that the mean reading scores of the children in the experimental groups are significantly different. The children in Group I are more advanced in reading than the children in Group II. Looking at Chart I, one can see that Group II made some progress in reading, but Group I made a greater advancement in the subject of reading. The difference shown is in favor of the activity program. Primary II Battery: Form B. Yonkers-on-Hudson, WorId Book Company, 1933. Tests 1,2 , and 3. 


\section{TABLE XVIII}

ARITHMETIC SCORES* OF TWO GROUPS OF SECOND GRADE CHILDREN AT END OF EXPERIMENTAL PERIOD

\begin{tabular}{|c|c|c|}
\hline & $\begin{array}{c}\text { Group I } \\
\text { June, I937 } \\
\end{array}$ & $\begin{array}{r}\text { Group II } \\
\text { Janury, } 1938 \\
\end{array}$ \\
\hline Mean Scores & 23.40 & 17.05 \\
\hline Range & 10 to 49 & 4 to 30 \\
\hline Standard Deviation & 9.55 & 8.01 \\
\hline $\begin{array}{l}\text { Standard Deviation } \\
\text { of Mean }\end{array}$ & 2.19 & 1.89 \\
\hline Difference between & & \\
\hline Means & & 6.35 \\
\hline $\begin{array}{l}\text { Standard Deviation } \\
\text { of Difference }\end{array}$ & & \\
\hline between Means & & 2.89 \\
\hline Critical Ratio & & 2.19 \\
\hline Significant & & robably \\
\hline
\end{tabular}

These data show that the mean arithmetic scores of the experimental groups are probably significantly different. The difference that is shown is in favor of the activity program. It must also be remembered that Group II was more advanced than Group I at the beginning of the experiment.

* Hildreth, Certrude H., Metropolitan Achlevement Tests Primary II Battery: Form B. Yonkers-on-Hadsoh, WorId Book Company, I933. T'est 4 and 5 . 
LANGUAGE USAGE SCORES* OF TWO GROUPS OF SECOND GRADE CHILDREN AT END OF EXPERIMENTAL PERIOD

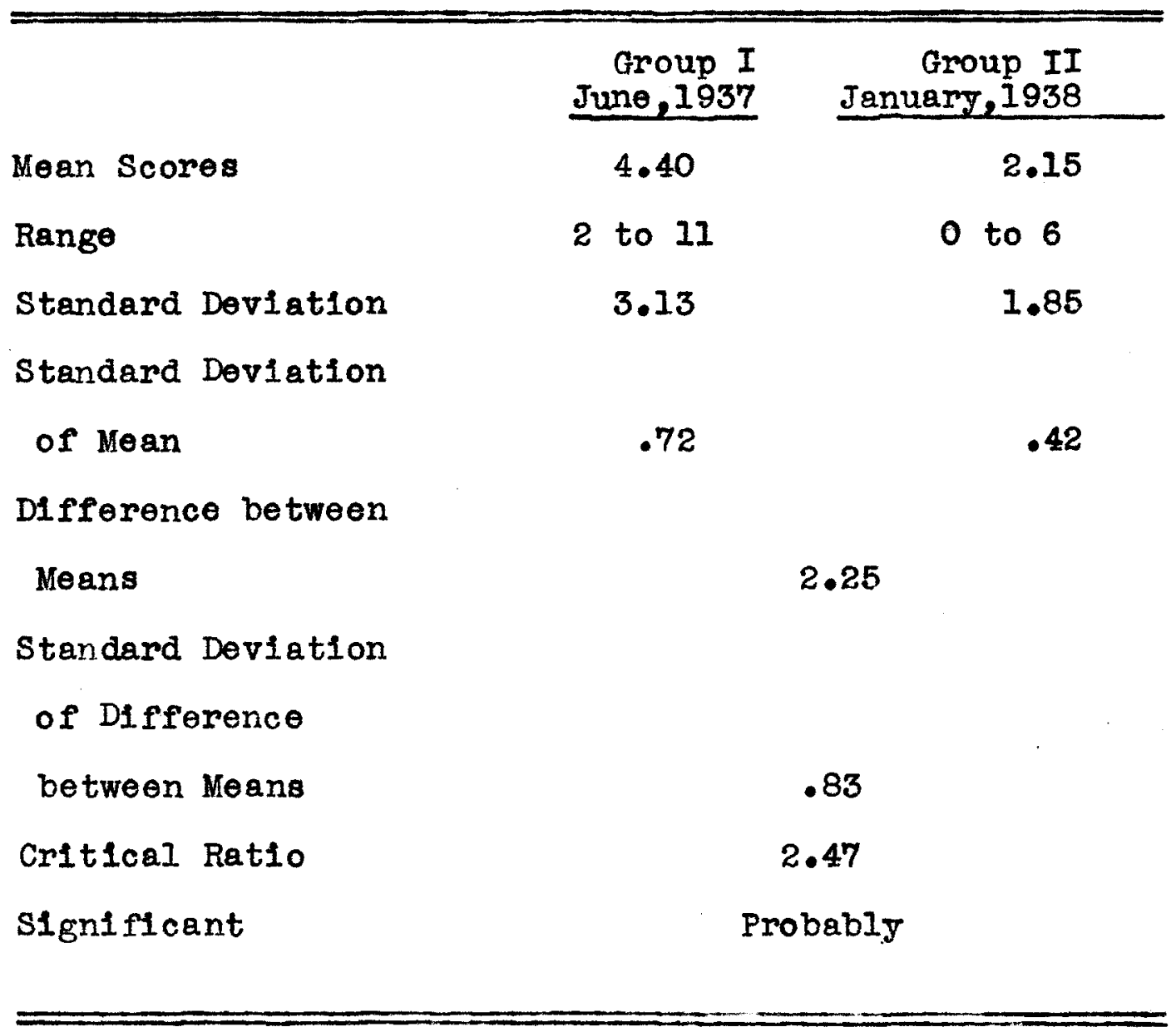

These data show that the mean language usage scores of the experimental groups are probably significantly different. The difference shown is in favor of the activity program.

* Hildreth, Gertrude H., Metropolitan Achlevement Tests Primary II Battery: Form B. Yonkers-on-Hudson, WorId Book Company, I933. Test $\frac{1}{6}$. 


\section{TABLE XX}

SPELLING SCORES* OF TWO GROUPS OF SECOND GRADE CHILDREN AT END OF EXPERIMENTAL PERIOD

\begin{tabular}{lcc}
\hline & $\begin{array}{c}\text { Group I } \\
\text { June, 1937 }\end{array}$ & $\begin{array}{c}\text { Group II } \\
\text { Janury, 1938 }\end{array}$ \\
\cline { 2 - 3 } Mean Scores & 8.65 & 4.95 \\
Range & 3 to 18 & 0 to 12 \\
Standard Deviation & 3.79 & 3.80 \\
Standard Deviation & & .87 \\
of Mean & .88 & \\
Difference between & & \\
Means & & 4.85 \\
Standard Deviation & & \\
of Difference & & \\
between Means & & \\
Critical Ratio & & \\
Significant & & \\
\hline
\end{tabular}

These data show that the mean spelling scores of the children of the experimental groups are significantly different. The children in Group I are distinctly superior in spelling to the children in Group II, at the close of the experiment.

* Hildreth, Gertrude H., Metropolitan Achlevement Tests Primary II Battery: Form B. Yonkers-oñ-Hudson, WorId Book Company, 1933. Test 
Dynamic Factors:

TABIE XXI

SOCIAL QUOTIENTS* OF TWO GROUPS OF SECOND GRADE CHILDREN AT END OF EXPERIMENTAI PERIOD

\begin{tabular}{|c|c|c|}
\hline & $\begin{array}{c}\text { Group I } \\
\text { June, } 1937 \\
\end{array}$ & $\begin{aligned} & \text { Group } \text { II } \\
& \text { Jan uary, } 1938 \\
&\end{aligned}$ \\
\hline Mean Quotients & 136.30 & 113.30 \\
\hline Range & 123 to 154 & 101 to 127 \\
\hline Standard Deviation & 10.98 & $7 \cdot 27$ \\
\hline \multicolumn{3}{|l|}{ Standard Deviation } \\
\hline of Mean & 2.52 & 1.67 \\
\hline \multicolumn{3}{|l|}{ Difference betweon } \\
\hline Means & . & 23.00 \\
\hline \multicolumn{3}{|l|}{ Standard Deviation } \\
\hline \multicolumn{3}{|l|}{ of Difference } \\
\hline between Means & & 3.01 \\
\hline Critical Ratio & & 7.64 \\
\hline Significant & & Yes \\
\hline
\end{tabular}

These data show that the mean social quotients of the children in the experimental groups are significantly different. The difference is in favor of the activity program. The social development of Group I proved greater than the soclel development of Group II. * Doll, Edgar A., The VIneland Soclal Maturity Scale. Ner Jersey. The Training School at vineland, New Jersey. I936. 
PERSONALITY RATINGS* OF TWO GROUPS OF SECOND GRADE CHILDREN AT END OF EX PERIMENTAL PERIOD

\begin{tabular}{|c|c|c|}
\hline & $\begin{array}{c}\text { Group I } \\
\text { June, } 1937 \\
\end{array}$ & $\begin{array}{c}\text { Group II } \\
\text { January, } 1938 \\
\end{array}$ \\
\hline Mean Ratings & 6.50 & 8.70 \\
\hline Range & 1 to 16 & 4 to 17 \\
\hline Standard Deviation & 4.23 & 3.61 \\
\hline \multicolumn{3}{|l|}{ Standard Deviation } \\
\hline of Mean & .97 & .87 \\
\hline \multicolumn{3}{|l|}{ Difference between } \\
\hline Means & & $2 \cdot 20$ \\
\hline \multicolumn{3}{|l|}{ Standard Deviation } \\
\hline \multicolumn{3}{|l|}{ of Difference } \\
\hline between Means & & 1.30 \\
\hline Critical Ratio & & 1.69 \\
\hline Significant & & No \\
\hline
\end{tabular}

These data show that the mean personality ratings of the children in the experimental groups are slightly, but not signiflcantly different. The difference that is shown is in favor of the activity program. Following the scoring on the test the mean ratings would be lower if the group had improved their personality adjustments during the experimental period. This factor is explained on p.45.

* Brom, Fred, Personallty Inventory For Children. New York. The Psychological Corporation, 1935. 
Performance Factors:

TABIE XXIII

COOPERATION RATINGS* OF TWO GROUPS OF SECOND GRADE CHILDREN AT END OF EX PERIMENTAL PERIOD

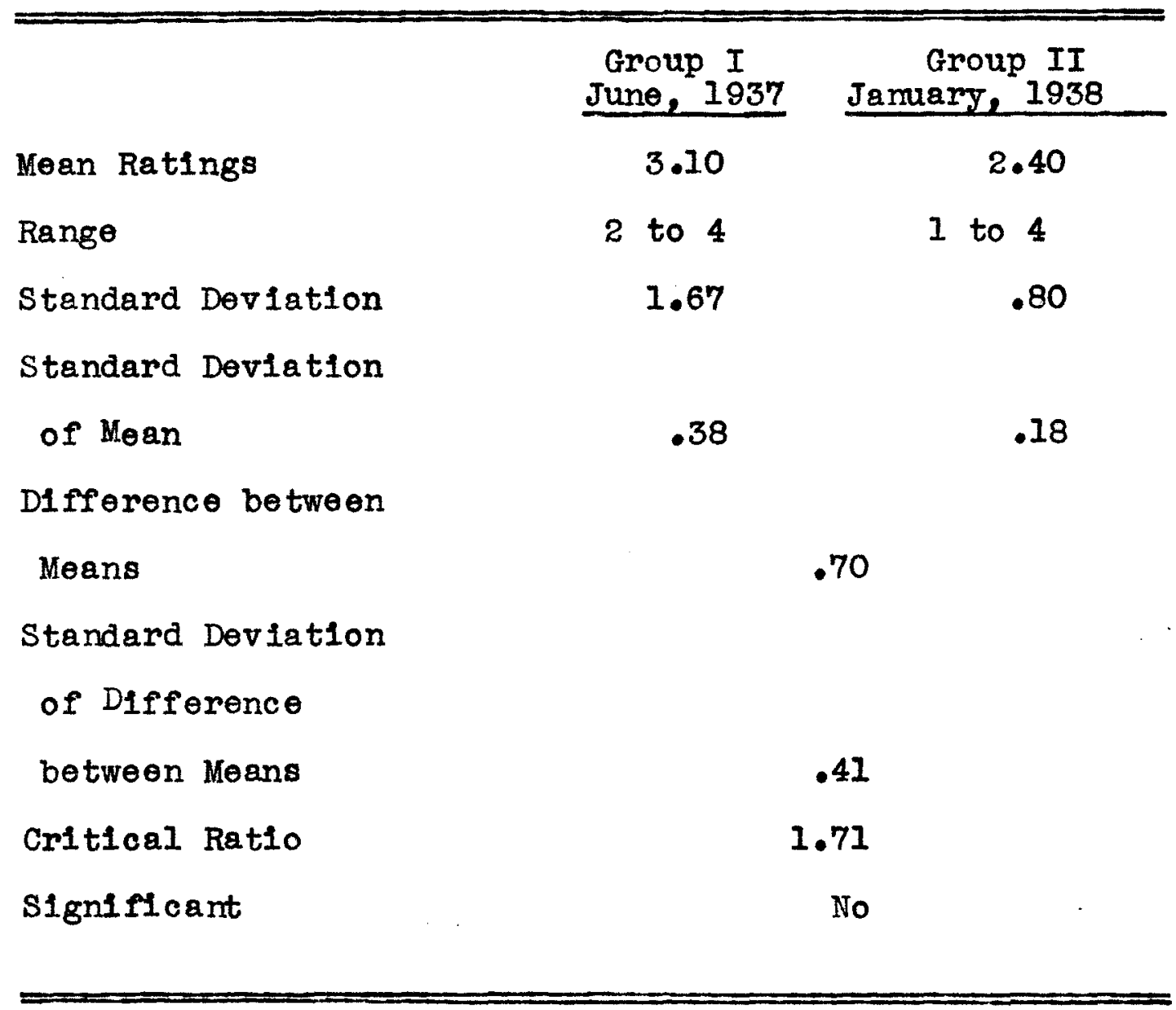

These data show that the mean ratings for cooperation of the children in the experimental groups are slightly, but not significantly different. The difference that is show is in favor of the activity program.

* Cooperation - Ratings secured from the writer's observations during the experimental period. 


\section{TABLE XXIV}

INITIATIVE RATINGS* OF TWO GROUPS OF SECOND GRADE

CHILDREN AT END OF EXPERIMENTAL PERIOD

\begin{tabular}{|c|c|c|c|}
\hline & $\begin{array}{r}\text { Group I } \\
\text { June, } 1937 \\
\end{array}$ & $\begin{array}{r}\text { Group } \\
\text { January }\end{array}$ & $L_{1938}^{\text {II }}$ \\
\hline Mean Ratings & 3.55 & & 2.10 \\
\hline Range & 2 to 4 & & to 3 \\
\hline Standard Deviation & .57 & & .63 \\
\hline \multicolumn{4}{|l|}{ Standard Deviation } \\
\hline of Mean & 13 & & .14 \\
\hline \multicolumn{4}{|l|}{ Difference between } \\
\hline Means & & 1.25 & \\
\hline \multicolumn{4}{|l|}{$\begin{array}{l}\text { Standard Deviation } \\
\text { of Difference }\end{array}$} \\
\hline between Means & & .20 & \\
\hline Critical Ratio & & 6.25 & \\
\hline Significant & & Yes & \\
\hline
\end{tabular}

These data show that the mean initiative ratings for the children in the experimental groups are significantly different. The difference is in favor of the activity program.

* Inftlative - Ratings secured from the writer's observations during the experimental period. 
PUPII PARTICIPATION RATINGS * OF TWO GROUPS OF SECOND GRADE CHILDREN AT END OF EXPERIMENTAL PERIOD

\begin{tabular}{lcc}
\hline & $\begin{array}{c}\text { Group I } \\
\text { June, I937 }\end{array}$ & $\begin{array}{c}\text { Group II } \\
\text { January 1938 }\end{array}$ \\
\cline { 2 - 3 } Mean Ratings & 3.10 & 2.30 \\
Range & 2 to 4 & 1 to 4 \\
Standard Deviation & 1.64 & .68 \\
Standard Deviation & & .16 \\
of Mean & .38 & \\
Difference between & & \\
Means & & .80 \\
Standard Deviation & & \\
of Difference & & \\
between Means & & \\
Critical Ratio & & \\
Significant & & \\
\hline \hline
\end{tabular}

These data show that the mean ratings for pupil participation of the chlldren in the experimental groups are significantly different. The difference shown is in favor of the activity program.

* Pupil Participetion - Ratings secured from the writer's observations during the experimental period. 
PUPIL OPINION RATINGS* OF TWO GROUPS OF SECOND GRADE CHILDREN AT END OF EXPERIME NTAL PERIOD

\begin{tabular}{lcc}
\hline & $\begin{array}{c}\text { Group I } \\
\text { June, 1937 }\end{array}$ & $\begin{array}{c}\text { Group II } \\
\text { January, 1938 }\end{array}$ \\
\cline { 2 - 3 } Mean Ratings & 3.35 & 2.05 \\
Range & 2 to 4 & .50 \\
Standard Deviation & .79 & .11 \\
Standard Deviation & & \\
of Mean & .18 & \\
Difference between & & 1.30 \\
Means & & \\
Standard Deviation & & \\
of Difference & & \\
between Means & & \\
Critical Ratio & & \\
Significant & & \\
\hline
\end{tabular}

These data show that the mean ratings for pupll opinion of the children in both experimental groups are significantly different. The difference that is shown is in favor of the activity program.

* Pupil opinion - Ratings secured from the writer's observations during the experimental period. 


\section{$\underline{\text { TABLE }}$ XXVII}

INTEREST RATINGS* OF THO GROUPS OF SECOND GRADE CHILDREN AT END OF EXPERIMENTAL PERIOD

\begin{tabular}{|c|c|c|c|}
\hline & $\begin{array}{c}\text { Group I } \\
\text { June, } 1937 \\
\end{array}$ & $\begin{array}{r}\text { Gro } \\
\text { Januar } \\
\end{array}$ & $\begin{array}{l}\text { Ip II } \\
Y, 1938\end{array}$ \\
\hline Mean Ratings & 3.30 & & 2.40 \\
\hline Range & 3 to 4 & 1 & to 4 \\
\hline Standard Deviation & 1.93 & & .47 \\
\hline Standard Deviation & & & \\
\hline of Mean & $\bullet 44$ & & .11 \\
\hline \multicolumn{4}{|l|}{ Difference between } \\
\hline Means & \multicolumn{3}{|c|}{.90} \\
\hline \multicolumn{3}{|l|}{ Standard Deviation } & of Difference \\
\hline between Means & \multicolumn{3}{|c|}{.45} \\
\hline Critical Ratio & \multicolumn{3}{|c|}{2.00} \\
\hline Significant & \multicolumn{3}{|c|}{ Probably } \\
\hline
\end{tabular}

These data show that according to the mean interest ratings of the children in both experimental groups there is probably a significant difference. The difference that is shown is in favor of the activity program.

* Interest- Ratings secured from the writer's observations during the experimental period. 
TEACHER RATING ON SCHOLARHIP OF TWO GROUPS OF SECOND GRADE CHILDREN AT END OF EXPERIMENTAL PERIOD

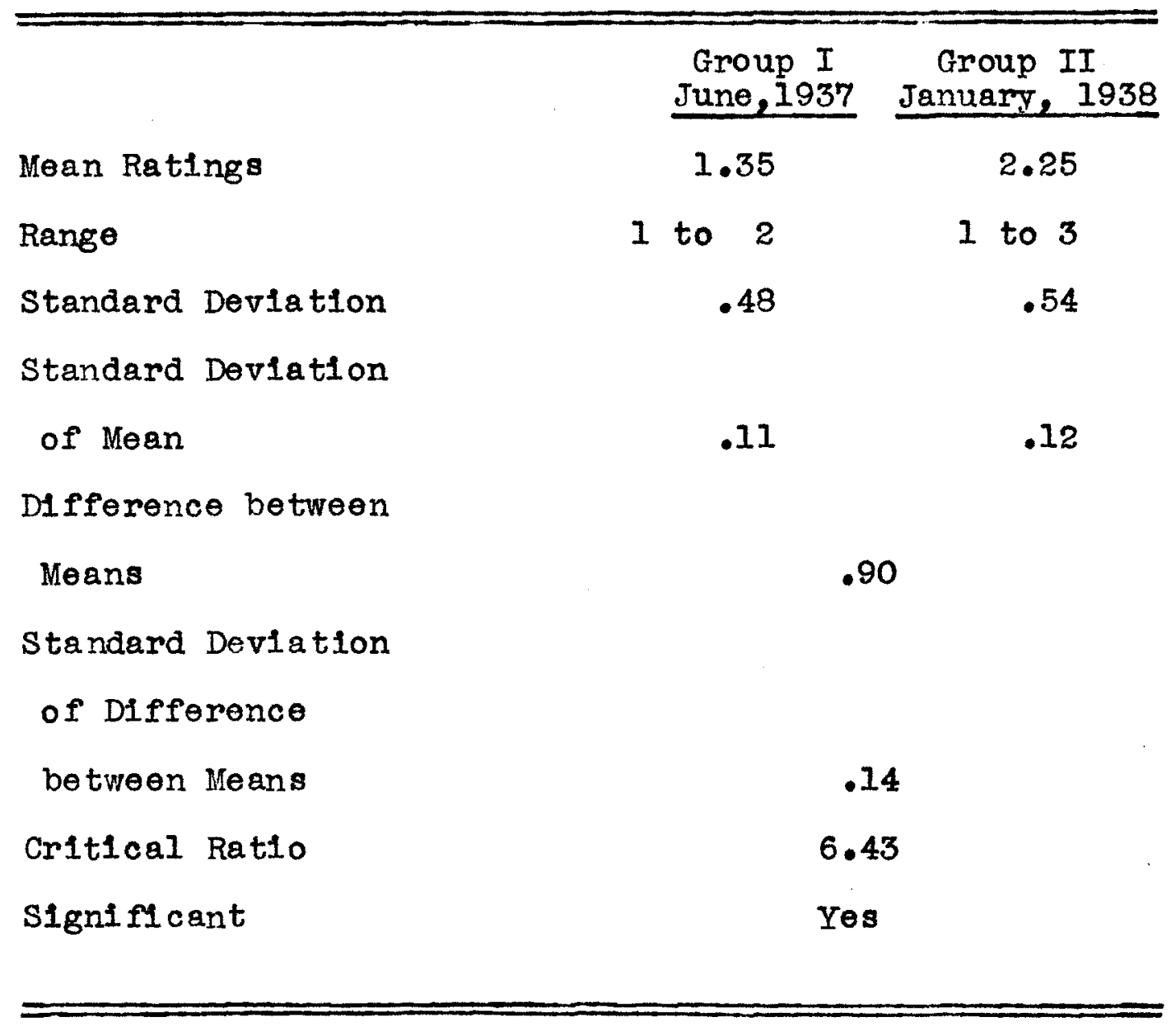

These data show that the mean teacher ratings of the children in both experimental groups are significantly different. The difference shown is in favor of the activity program. (For evaluation of rating scale see foot note $\mathrm{p} .31$ ). 
TABIE XXIX

SUMMARY GIVING THE MEANS, STANDARD DEVIATIONS, STANDARD DEVIATION OF THE MEANS, DIFFERENCE

OF THE MEANS, STANDARD DEVIATIONS OF DI FFERENCE, AND CRITICAL RATIO OF THE UNITS ON THE LIBRARY, DRY GOODS STORE, AND POST OFFICE. GROUP I - ACTIVITY GROUP. GROUP II FORMAL GROUP

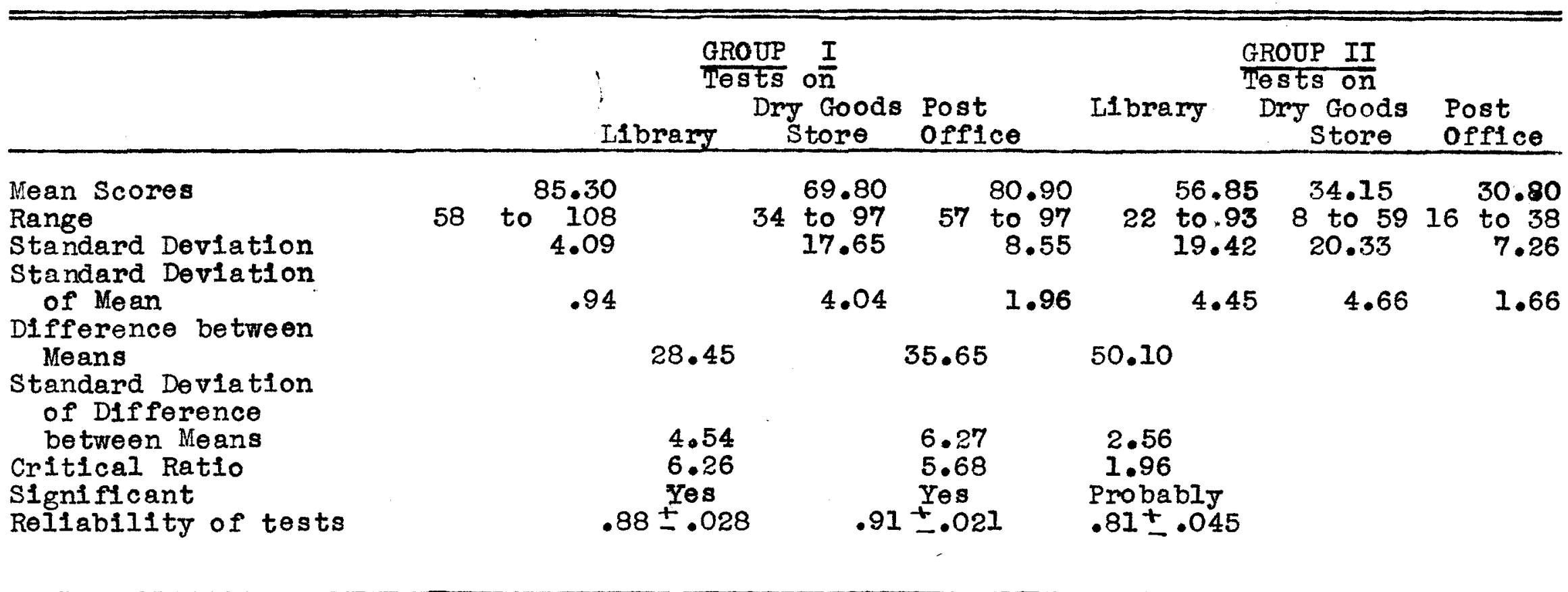


tests of the units on the Ifbrary, Dry Goods Store, and Post office. There is a significant difference for the Library and Dry Goods Store while on the other hand only a slight difference is shown for the Post office. This slight difference may be due to the fact that the children working by the traditional textbook method may have had experience regarding the Post Office.

Summary of the Data: A summary of the data from all initial testing and ratings of both experimental groups is given in Table XXX. This includes means, standard deviations, standard deviations of the means, differences between means, standard deviations of the differences between means, differences between means divided by the standard deviations of these differences, and a statement as to whether differences between means are statistically significant. A difference is considered significant if it is two or more times greater than its standard deviation. Table $\mathrm{XXX}(\mathrm{p} .67)$ is, actually, a surmary of Tables I to XV, inclusive.

Examination of Table XXX shows that Group I was significantly superior to Group II at the beginning of the experimental perlods in spelling and Social Maturlty. Group II was superior to Group I in Paragraph Meaning Score and Arlthmetic Fundamentals 


\section{$\underline{\text { TABLE }} \underline{\mathrm{XXX}}$}

SUMMARY OF INITIAL DATA FOR READING, ARITHMETIC, LANGUAGE, SPELLING, SOCIAL QUOTIENT, PERSONALITY, COOPERATION, INITIATIVE, PUPIL PARTICIPATION,

POPIL OPINION, INTEREST, AND TEACHER RATINGS, GIVING THE MEAN,

STANDARD DEVIATION, STANDARD DEVIATION OF THE MEAN, DIFFERENCE

OF THE MEANS, STANDARD DEVIATION OF THE DIFFERENCE。 AND THE

CRITICAL RATIO. GROUP I - ACTIVITY GROUP

GROUP II - TRADITIONAL GROUP

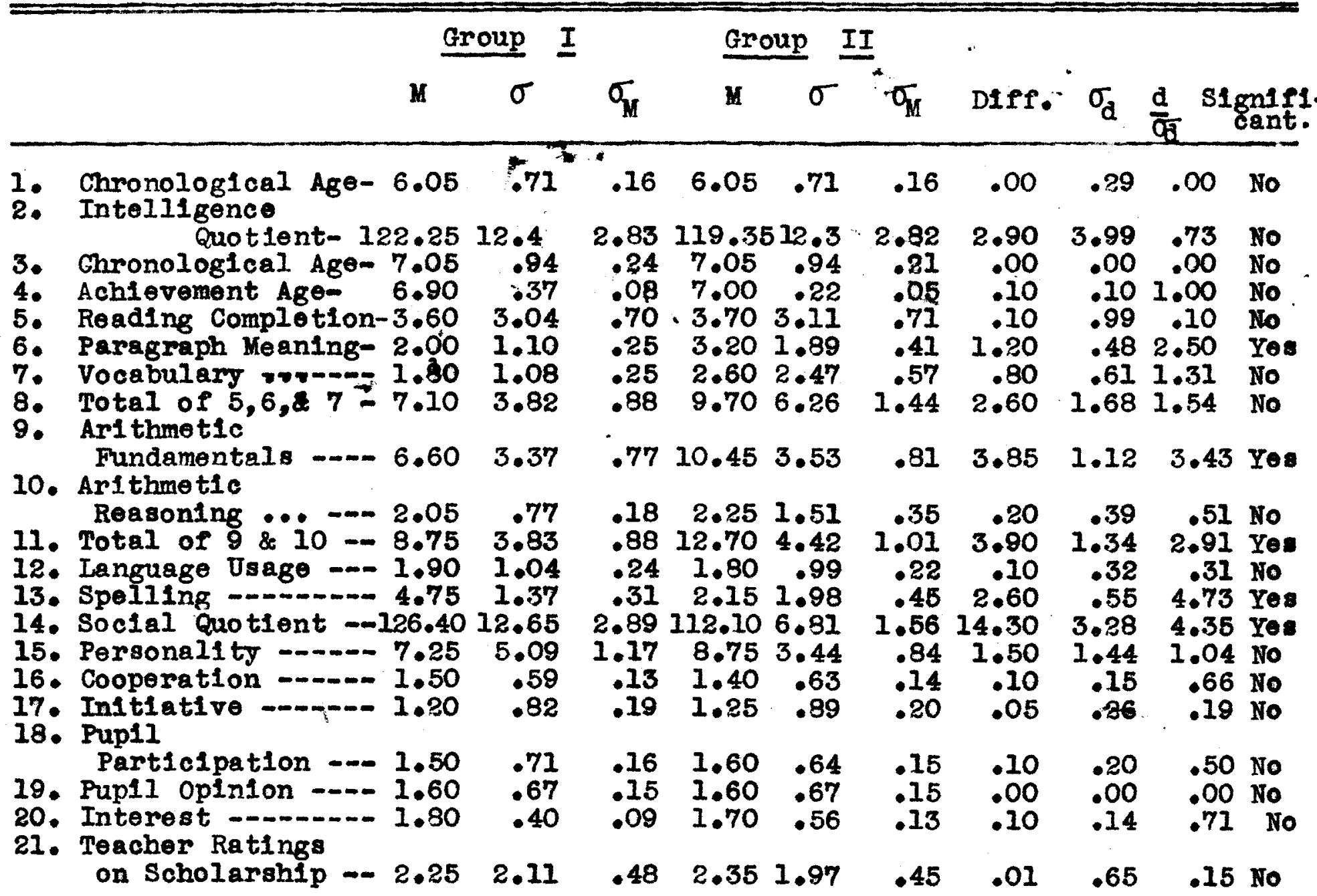

Keg:

$M=$ Moan

$\sigma=$ Standard Deviation

$\sigma_{M}=$ Standard Deviation of Mean

Diff. = Difference between Mean $\sigma_{\mathrm{d}}=$ Standard Doviation of Difference between Means

$\frac{d}{\psi}=$ Critical Ratio. 
Score. No signiflcant difference was found between group means on any other of the measures.

From these data it may be concluded that the two experimental groups were relatively comparable at the beginning of the instructional periods on most of the factorgfrdinarily associated with school achievement. As will be shown later, certain of the mean differences that were significant at the beginning of the experimental perlods had been eliminated or falled to appear at the end of the experimentel periods.

In Table XXXI (p.69) is given a summary of the final data of all testings and ratings of both experimental groups. This summary includes the same factors as given in Table XXX with the exceptions of chronological age and intelligence quotients.

Table XXXI shows statistically significant superiority of the group of children taught by the activity program over those taught by the traditional textbook method at the end of the training perlod in practically every aspect of achlevement tested or rated. General achievement was higher. Reading Completion, Paragraph Meaning, and Vocabulary were higher. Arithmetic Reasoning, Language Usage; Spelling, Soc1al Maturity, Inltiative, Pupll Participation, Pupil OpInion, Interest, and Scholarship scores or ratings were on the average superior. They 
TABIE XXXI

SUMARY OF FTNAL DATA FOR READTNG, ARITHMETIC, LANGUAGE, SPELIING, SOCIAL QUOTIENT, PERSONALITY, COOPERATION, INITIATIVE, PUPIL PARTICIPATION,

PUPIL OPINION, INTEREST, AND TEACHER RATINGS, GIVING THE MEAN,

STANDARD DEVIATION, STANDARD DEVIATION OF THE MEAN, DIFFERENCE

OF THE MEANS, STANDARD DEVIATION OF THE DIFFERENCE, AND THE

CRITICAL RATIO. GROUP I - ACTIVITY GROUP• GROUP II

TRADITIONAL GROUP

$$
\begin{aligned}
& \text { Group I Group II } \\
& \text { M } \sigma \quad \sigma_{M} \quad M \quad \sigma \quad \sigma_{M} \text { Diff. } \sigma_{\mathrm{d}} \frac{\mathrm{d}}{\sigma_{\mathrm{d}}} \text { ficant }
\end{aligned}
$$

1. Achievement Age - 7.90

2. Reading Completion- 12.25

3. Paragraph Meaning - 8.90

4. Vocabulary -...- 5.80

5. Total of $5,6, \& 7-26.95$

6. Arithmetic

Fundamentals -...- 19.05

7. Arithmetic Reason-

ing -

8. Total of 9 \& 10 ...

9. Language Usage -...-

10. Spoiling -- -

11. Social Quotient -.-

12. Personallty -......-

13. Cooperation -......

14. Initiative ........

15. Pup11

Particlpation -.-

16. Pup11 Opinion .....

17. Interest

18. Teacher Ratings

on Scholarship --
4.35

23.40

4.40

8.65

136.30

6.50

3.10

3.35

2.09

9.55

3.13

3.79

10.98

4.23

1.67

.57

3.10

3.35

3.30

1.64

.79

1.83

1.35

.48
.20

.59

.85

.76

1.91

1.82

(1)

14.45

7.25

5.25

.44

.10

.65

.144 .64 Yos

5.83 Yes

$\begin{array}{lllllllll}5.45 & 5.62 & 1.29 & 3.45 & 1.54 & 2.34 & \text { Yos }\end{array}$

$\begin{array}{lllllllll}3.65 & 2.36 & .54 & 2.15 & .93 & 2.31 & \text { Yes }\end{array}$

$14.6012 .162 .7912353 .38 \quad 3.65$ Yes

6.241

$1.43 \quad 4.60$

2.311 .99

Probably

.48

2.65

1.57

.361 .70

.603 .16 Yes

2.19

17.05

8.01

1.89

6.35

$2.892 .19 Y 08$

2.15

1.85

.422 .25

.832 .47 Yes

.88

$4.95 \quad 3.80$

. 87

4.85

1.233 .95 Yes

2.52

113.30

7.27

1.672300

3.01

7.64 Yes

$\bullet 97$

8.70

3.61

.872 .20

1.301 .69 No

.38

2.40

.80

.18 .70

$.411 .71 \mathrm{No}$

.13

2.10

.63

.141 .25

$.206 .25 \mathrm{Yes}$

.38

2.30

.68

.16 .80

.204 .00 Yes

.182 .05

.50

.47

.111 .30

.206 .50 Yes

.44

2.40

.11 .90

.452 .00 Yes

.11

2.25

.54

.12 .90

.146 .43 Yes

Xer:

II = Mean

$\sigma=$ Standard Deviation

$q_{1}$ - Standard Deviation of Mean

Diff. = Difference between Mean
$Q_{\text {a }}=$ Standard Deviation of

Difference between Means

$\frac{d}{\partial t}=$ Critical Ratio. 
were superior, probably, in Arithmetic Fundamentals, did considerably better in terms of teachers' ratings of cooperation and were slifhtly higher on ratings of Personality Adjustment.

These findings are the more striking when it is recalled that they were significantly superior, as a group, at the beginning of the experiment only In Spelling and Social Maturity and that the group taught by the traditional method excelled them in reading for Paragraph Meaning and Arlthmetic Fundamentals.

The nature of these changes is shown graphicaliy by Charts I, II, III, and IV. In these charts data for the group taught by the activity program method are shown as solld black bars at the beginning of the experimental period and data for those taught by the traditional textbook method are shaded. The unshaded portions of the bars indicate the gains made during the experimental periods. Chart I summarizes the data on Intellectual Factors measured by the Metropolitan Achlevement Test and teachers' ratings on scholarship. Chart II summarizes the data on Soc1al Maturity as measured by the Vineland Scale. Chart III shows initial and final scores on the Brown Personality Inventory. Chart IV shows teachers' ratings at the beginnings and 
endings of the experimental pertods on cooperation,

initiative, pupil participation, pupil opinion, and

interest as defined elsewhere in this thesis (p.31).

\section{CHART I}

MEAN ACHIEVEMENT OF EQUATED GROUPS IN READING, ARITHMETIC, LANGUAGE USAGE, SPELIING, AND TEACHER RATINGS UNDER ACTIVITY PROGRAM AND TRADITIONAL PROCEDURE

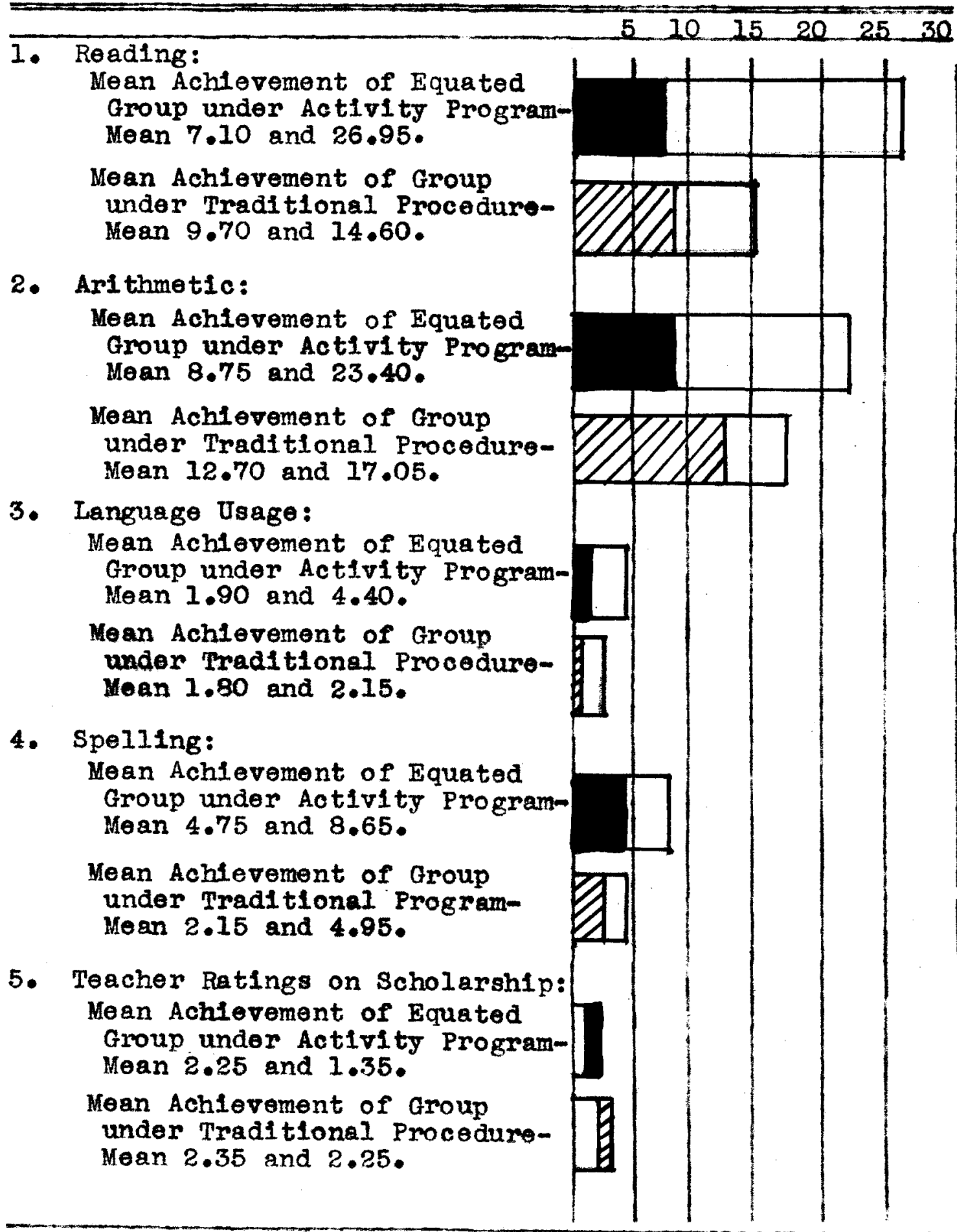


SOCIAL QUOTIENTS OF TWO GROUPS OF SECOND GRADE CHILDREN AT THE BEGINNING AND ENDING OF EXPERIMENTAL PERIOD

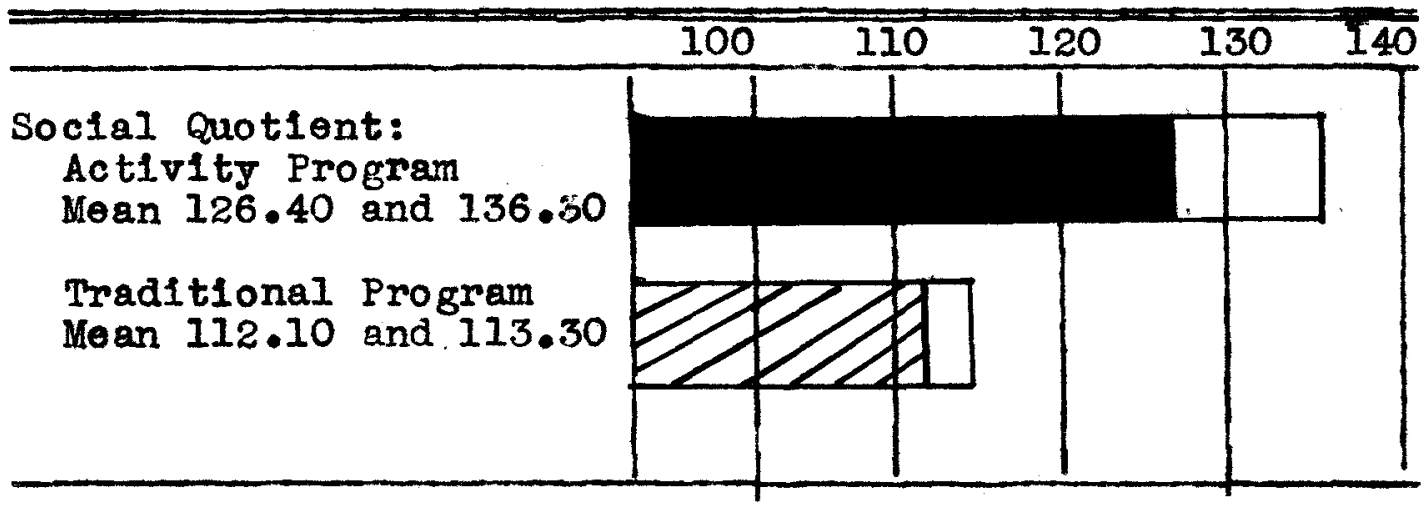

\section{CHART III}

PERSONALITY RATINGS OF TWO GROUPS OF SECOND GRADE CHILDREN AT THE BEGINNING AND ENDING OF EXPERIMENTAL PERIOD

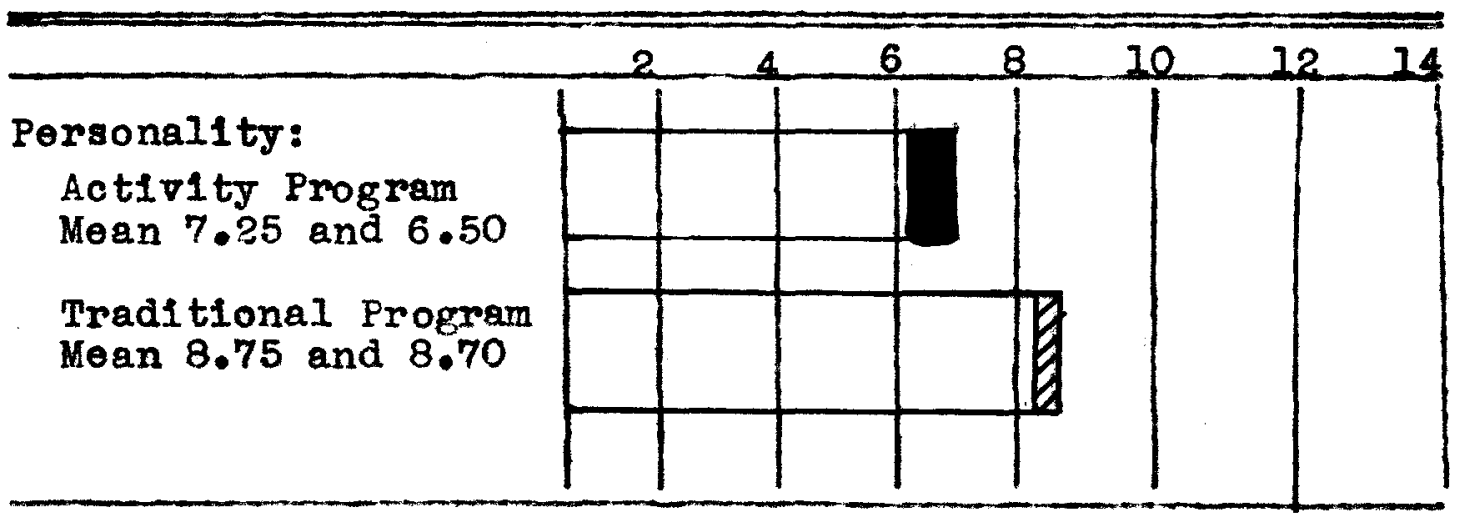




\section{CHART IV}

PERFORMANCE FACTORS OF TNO GROUPS OF SECOND GRADE CHILDREN AT THE BEGINNING AND ENDING OF EXPERIMENTAL PERIOD

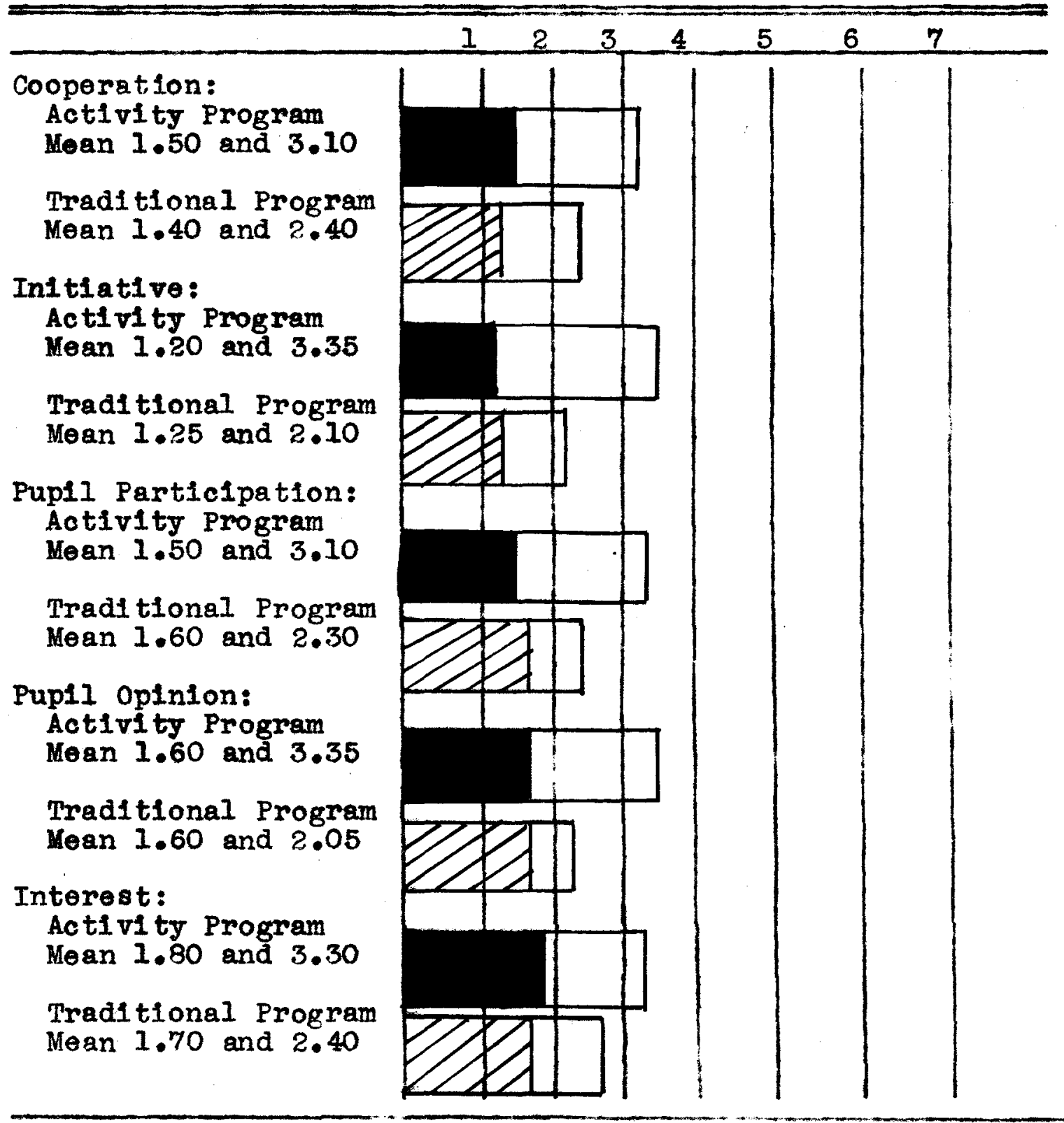


Additional light may be thrown on the results of the experiment by combining the data from the two groups prior to and at the end of the instmuctional perlods. This may be done by adding the critical ratios as they favor one group or the other in an effort to secure net results. This is done in Table XXXII ( $p, 75)$ where the data for the group taught by the activity program method are given as plus or minus values relative to the children taught by the traditional textbook method. For example, Group I scored 1.00 critical ratios below Group II in general achievement at the beginning of the experiment. This is called -1.00 . At the end of the period they scored 4.64 critical ratios above Group II. This is called 4.64. The net gain may then be thought of as 5.64 critical ratios in favor of the group taught by the activity program method. (It will be remembered that a critical ratio is defined as a difference between means divided by the standard deviation of this difference.) 


\section{TABLE XXXII}

NET GAINS AND LOSSES OF A GROUP OF TWENTY CHILDREN

TAUGHT BY THE ACTIVITY PROGRAM METHOD AS COM-

PARED WITH A SIMILAR NUMBER OF CHIIDREN TAUGHT

BY THE TRADITIONAL TEXTBOOK METHOD FOR A LIKE

PERIOD. (Data ere in terms of critical

rat10s -- mean differences divided by standard deviations of these differences.)

\begin{tabular}{|c|c|c|c|}
\hline Test or Rating & Initial & Fina 1 & Net Gain \\
\hline $\begin{array}{l}\text { Achievement Age } \\
\text { Reading Completion } \\
\text { Paragraph Meaning } \\
\text { Vocabulary } \\
\text { Arlthmetic }\end{array}$ & $\begin{array}{l}-1.00 \\
-.10 \\
-2.50 \\
-1.31\end{array}$ & $\begin{array}{l}+4.64 \\
+5.83 \\
+2.34 \\
+2.31\end{array}$ & $\begin{array}{l}5.64 \\
5.93 \\
4.84 \\
3.62\end{array}$ \\
\hline $\begin{array}{l}\text { Fundamentals } \\
\text { Arithmetic }\end{array}$ & -3.43 & +1.99 & 5.42 \\
\hline $\begin{array}{l}\text { Reasoning } \\
\text { Language Usage } \\
\text { SpeIling } \\
\text { Soc1al Maturity }\end{array}$ & $\begin{array}{r}-.51 \\
+\quad .31 \\
+4.73 \\
+4.35\end{array}$ & $\begin{array}{l}+3.16 \\
+2.47 \\
-3.95 \\
+7.64\end{array}$ & $\begin{array}{r}3.67 \\
2.16 \\
-\quad .78 \\
3.29\end{array}$ \\
\hline $\begin{array}{l}\text { Personality } \\
\quad \text { Adjustment } \\
\text { Cooperation } \\
\text { Initiative } \\
\text { Partic ipation } \\
\text { Pupll opinion } \\
\text { Intereat } \\
\text { Scholarship Rating }\end{array}$ & $\begin{array}{r}-1.04 \\
+\quad .66 \\
-.19 \\
-.50 \\
0.00 \\
+\quad .71 \\
-.15\end{array}$ & $\begin{array}{r}-1.69 \\
+1.71 \\
+6.25 \\
+4.00 \\
+6.50 \\
+2.00 \\
+6.43\end{array}$ & $\begin{array}{l}.65 \\
1.05 \\
6.44 \\
4.50 \\
6.50 \\
1.39 \\
6.58\end{array}$ \\
\hline
\end{tabular}

If these data are accepted at all reasonably it may be said, with justification, that the children taught by the activity program method made very superior gains, on the average to those taught by the traditional textbook method. It is interesting to note here that the teacher who received the groups following the experimental periods reported that 
those who had experienced the activity program were more observant and better behaved when taken on trips, that they could draw better plctures of what they saw and could express themselves more freely when relating their experiences. Further discussion of the findings is given in Chapter $V$. 
SUMMARY 


\section{CHAPTER V}

\section{SUMMARY}

I. The history of the activity program and Its characteriatics as contrasted with the traditional textbook method are discussed in Chapter II. The activity program, according to the ilterature, cannot be ascribed to any one man or any school system. It has a long history and many persons have assisted in Its growth. Frencis W. Parker first interpreted the principles of activity for America. He used the theory of education along the lines which Pestalozzl and Froobel had developed, that is, making native endowment of the child rather than the curriculum the center of attention on the part of the educator. In 1ts present form, however, the activity program owes most to the group of educetors and philosophers headod by Dewoy, Kilpatrick, Childs, Bode, Collings, and Melvin.

The work these men have done has attracted a wide following, and he influenced educational thought in all parts of the world. So wide-spread has been this influence, that today there are scarcely any purely formal schools. In some cases, only isolated bits of the activity plan have 
become effective but, in a fow cases, whole systems have been transformed completely.

A comparison of the activity program and the traditional textbook method as revealed in the educational. literature is about as follows:

\section{Act1v1ty Program Traditional Textbook Method}

I. Makes the child the 1. Makes the curriculum center. the center.

2. Comes from within. 2. Comes from without.

3. Is active, creative. 3. Is pasive, recelving.

4. Makes school Iffe 4. Makes school iffo natural. artificlal.

5. Considers present 5. Prepares for adulthood. neods.

6. Is evolving.

6. Is conserving.

7. Uses the natural or 7. Uses the textbook or psychologlcal approach. logical approach.

8. Cultivates inductive- 8. Cultivates deductive deductive thinking. thinking.

9. Fuphasizes developing 9. Emphesizes drill and judicial memory. mechanical memory.

10. Encourages the gain- 10. Stores information. ing of know ledgo. 11. Cultivates open- 11. Tends toward a closed
mindedness.

II. The aims of an activity program at the second grade level may be summarlzed as follows: 1. To protect and develop health. 
2. To safeguard mental health.

3. To promote social adjustment.

4. Provide for growth and development.

5. To treat each child as an individual.

6. Supply 1deas and occupations suitable for chlidren's lolaure.

7. Dovelop certain skills and techniques.

8. Establish attitudes of appreclation of Iffe, of beauty, and of fineness.

The witer investigated the effects of instruction of second grade children by two widely different methods - the activity program and traditional textbook procedures. Thirty second grade children in the Longfellow School of Louisville were examined and rated during the first week of the semester beginning February 22, 1937. The tests used were: (1) The Metropolitan Achlevement Test, Primary Examination Form A, (2) The Vinoland Soclal Maturity Scale, and (3) Brown's Personality Inventory. Intelligence quotient ratings were avallable from tests given the previous year. The children were rated cooperatively in conference by the writer and the teacher who had had them the previous semester on: (I) cooperation, (2) Inltiative, (3) pup1l participation, (4) pup1l opinion, (5) interest, and (6) scholarship. Following this inftial week the children recoived instruction by the writer according to a 
carefully prepared activity program involving trips to (1) a library, (2) a dry goods store, and (3) a post office. Every effort was made to conform to the procedures laid down in the literature as essential to an activity program. The children were led to inltiate their own activities, did most of their own planning, and, actually were very active in all of the school work done during the semester. They made a library in the school room; they built and operated a dry goods store, and a post office. Drills, examinations, oral and written compositions, spoling, grammar, reading, arithmetic, drawing, and music were organized around the group activities of the children.

The last week of the semester (June, 1937) the children were examined and rated again exactly as during the first week of the semester using alternate forms of tests wherever possible. All data relative to the semester's work were carefully preserved. A complete description of the procedures followed is given in Appendix "A :"

The firgt week of the following semester (September, 1937) another group of thirty second grade children in the same school was tested and rated exactly as were the children in this class the first week of the preceding semester. The remalnder 
of the semester was devoted to instruction by traditional textbook procedures as outlined in Appendix "B" of this thes1s. Every effort was made to follow the customary formalities of the method. The textbooks were followed, page by page, assignments were exactiy as prescribed in outilnes and courses of study. Drills and examinations were as formal as was the discipline. The last week of the semester (January, 1938) the chlldren were tested and rated exactly as at the beginning of the semoster and as were the children at the close of the previous semester who had been taught by the activity program. With all data from the two classes of second grade children avallable the writer attempted an evaluation or comparison of the two methods of Instruction. First, data for those children who had not been present at least ninety-five per cent of the semester and who had not taken all of the teats were eliminated. Next, an effort was made at securing from the two classes two groups of children as comparable in terms of group averages as was possible and still keep a large enough number in each group that group comparisonswould be statistically reliable. In dolng this a child from the group taught through the activity program was paired with a child taught by the traditional method on the basis 
of Iife, age, intelligence quotient, total and part scores on the Metropolitan Achievement Test, The VIneland Scale, The Personality Inventory, and the varlous ratings of the teachers, all taken from data secured during the first weeks of the instructional per1ods - February, 1937, and September, 1937. Twenty such pairings were secured for whom all essential data were avallable. (See Appendix " $C^{n}$ )

Averages, standard deviations, differences between averages, and standard deviations of the differences between averages were calculated from the Initial data for these two groups of children using the customary statistical procedures describod in Chapter IV. It was found that group averages differed two or more standard deviations in only four of the eighteen measures used, the group taught through the activity program being superior on the average to those taught by the traditional method in Social Maturity and spolling at the beginning of the experimental periods. The group taught by the traditional method excelled the other group, on the average in Reading: Completion and Arithmetic Fundamentals, at the beginning of the instructional period. Differences between group averages were not statistically reliable for any others of the measures used. From these findings it was concluded that the two groups 
of second grade children were reasonably comparable, so far as group averages are concerned, at the outset of the instructional periods in those factors - age, intelligence quotients, achievement, scholarhip, cooperation, initiative, pupil participation, pupil opinion, and interest, usualiy considered to be related to scholastic success. Whatever differences might be found between them, as groups, in achlevements, skills, attitudes, maturity, and adjustments, following widely differing methods of Instruction should be credited, tentatively at least, to differences in instructional methods, was the conclusion arrived at. The data for these initial tostings and ratings are given in full in Appendix " $C$ " and group comparisons are summarized in Table XXX.

Data secured during the final weeks of the semesters were next examined to determine what changes had taken place in these two groups of children and how they compared with each other following a semester's instruction each by widely different methods in the same classroom and under the same teacher.

Group averages, standard deviations, standard deviations of the means, and differences between means, were calculated exactly as for the 
date from the initial testing and rating procedures. These are given in Table XXXI for the groups as units. Complete individual data are given in Appendix "C :"

\section{Findings:}

1. Both groups made improvement in mastery of subject matter, in scholarship, and in personality characteristics, as rated by teachers and by standard rating scales. Group I gaired 1.0 grades and Group II gained 44 of a grade as measured by the Metropolitan Achievement Test during the single semester of instruction.

2. The group taught by activity program methods (Group I) scored and rated significantly higher on the average than did the group taught by traditional methods (Group II), on practically all aspects of achievement considered: (1) General Achievement as measured by the Metropolitan Achlevement Test; (2) Reading Completion, Paragraph Meaning, Vocabulary, Arithmetic Reasoning, Language Usage, Spolling, and (probably) Arlthmetic Fundamentals as measured by the same test; (3) Social Maturity as measured by the Vineland Scale, and (4) Initiative, Pupil Participation, Pupil Opinion, Interest, and Scholarship as judged by teachers' ratings.

3. Group I scored slightly better in Adjusted Personalities than did Group II.

4. The greatest average gains made by 
the children experiencing the activity program were

In (1) Scholarship; (2) Pup1l Opinion, and (3)

Inltiative; the least gains wero mado in: (1) Spolling;

(2) Personality Adjustment, and (3) Cooperation.

5. The children taught by the traditional

textbook method made their greatest gains in: (1)

Arithmet1c Fundamentals; (2) Paragraph Meaning, and

(3) Speling. Their smallest gains were in: (1) Pup11

OpInion; (2) Interest, and (3) Pupil Participation.

\section{Conclusions:}

1. The activity program as dofined

In educational literature and interpreted by the writer is distinctiy superior to the traditional textbook method as a means of instructing ch1ldren at the second grade level with conditions as they were in this experiment.

\section{Superiority of the activity}

program as a means of instruction with conditions as they were throughout this investigation is most marked in scholarship as judged by teachers' ratings.

3. The activity program was much more enjoyable, not only to the children, but to the teacher as well, desplte her ten year's teaching experience by the traditional textbook method or with minor adaptations of 1 . 
4. The findings of this investigation warrant a careful experimental evaluation of the activity program as a means of instruction under a wide variety of conditions, with different types of children, different teachers, other school grades, and other school systems. Not unt1l such investigations are made are we justifled in saying what might be galned by such procedures as opposed to other teaching methods, or in concluding what aspects of the activity program might justifiably be incorporated in a general educational program. 
APPENDIX A

UNITS 


\section{APPENDIX A}

UNITS

The activities of an activity program comprise a body of material that trains for living. They deal with problems of human welfare and attempt to teach ultimately that society is a cooperativeproposition and that each individual is a unit contributing to the whole. The children just beginning in school talk about their homes. It is where their interests and experiences 110. The first grade teacher usually finds that her first activity unit is the study of the home. Why? Because the family group is the first soolal group with which the child has definitely establishod relations and therefore it is the focusing point of his relations to the world environment. The home is his best known experience and it gives him a foundation on which to bulld larger experiences that grow as he grows; it is a channel through which his experiences come to him and through which he interprets them. These experiences of the first grade child form a background for future work in an activity program.

The home is not an 1solated unit 
complete in Itself, but, by virtue of some economic arrangement, recelves the wherewithal necessary to carry on 1ts 11 fe from the community. Long before the Home Unit has been completed the connections have been made between the home and varlous factors in the community which supply the home. The more important factors of the community should be treated in detall to awaken the child's intelligent interest in the life about him, to give him an appreciation of the work others do for him, and show him how interdependent are the lives of people in the community. The child's ilfe is so bound up with these various agencles and they are so close to his experiences that they form a ladder to lead him from the known to the less famillar. The community is the first break from the small home circle to a larger circle that keeps on widening and extending the child's experiences. He flrst sees the community as a whole; then gradually he becomes consclous of a particular phase here that is linked closely with the home, which helps to supply protection, pleasure, or necessity. Experiences connected with the Home Iffe Unit help the child to interpret the phasea of the community as he becomes acqualnted with 
them. During this period while the child is in the first grade it is likely that he has studied home life and the community as a whole, but when he enters the second grade the child has a desire to learn about the more specific phases of the community, such as, the I1brary, the dry goods store, the post office, and the dafry. The child is interested in how each of these phases operate.

The following pages describe the units carried on in the writer's second grade of a public school in Loulsville, Kentucky, during the semester of February, 1937. Units were worked out by the writer in her own class during the above mentioned semester. The units are: I. The Library; II. The Dry Goods Store; and III. The Post office.

\section{ONIIT I \\ THE LIBRARY}

I. Approach and Procedure:

A. Approach: This is a description of the unit carried out by the second grade of the Longfellow School in Louisville, Kentucky, during the semester bef February, 1937. The children had 
been out of school for one month because/flood conditions in the city. The teacher had made the room as attractive and interesting as she could. In a bright cormer of the room there was an attractive book table upon which were arranged a number of children's books. One day the teacher said, "We have so many books that this table will hardly hold them. Where shall we put some of them?"

$$
\text { Immediately the response from one }
$$
ch1ld was, "Put them in the book case." Another said, "We couldn't get the books when we wanted them if we put them in the book case." The only book case this child thought of was the big cabinet in the room where all the supplies are kept.

$$
\text { Another sald, "Couldn't we make some }
$$
book shelves?"

At this time the teacher asked, "Where do people usually go when they wish to read?"

Some one said, "To the library." The children Immediately wanted to have a library in the room.

The next day the teacher opened the discussion by reminding the children of their 
suggestion to build a library.

"What can you tell about the inside of a library?" asked the teacher.

These are some of the things the children knew the library had - shelves, tables, chairs, books, and magazines.

At this point the teacher asked, "If we are going to build a library in our room, don't you think it would be a good idea if we go to a library and look around first? Then we would have a better idea about bullding ours. Let us be sure to look at everything to see what we really need to put in our library."

A child asked, "When can we go?" The teacher replied, "It will be necessary to ask the librarlan when we can come." The children were very enthusiastic about this suggestion and planned a trip to the library. The children declded to write a letter. to the librarian. This is the letter they wrote.

\section{Loulsville, Ky.,} Feb. 24, 1937.

Dear Miss

We want to build a library in our room. We would like to come to see the library before we bulld ours. When could we come? 
Each child made a copy of the above letter. The letter written the best was selected to be sent to the librarian. The Iibrarian answered the children's letter stating that they could come on Tuesday.

Before the class could go to the library there was muchplanning necessary. Since the Highland Branch Library was some distance from the school the children asked, "How can we go?"

Someone suggested that the mothers take them in cars. The teacher took the names and telephone numbers of children whose mothers could drive cars. The teacher secured five cars. The chlldren whose mothers were driving chose several children to ride with them. The children decided to ask four other children beside themselves. They decided this because they realized it was not safe to ride in a car that is crowded, also that it was a great responsibility to have other children riding with the mothers.

After having all arrangements made for the trip, the children talked about 
how they would act while at the library; all agreed that each child must remember to speak quietly so that the people who were reading would not be disturbed. The children had questions for which they wanted to find answers. These questions were printed on a chart and hung up for the children to read.

1. Who owns the library?

2. Where does the library get the books?

3. Who goes to the Ilbrary?

4. How to make book shelves?

5. What should we put in our library?

6. How much do books cost?

7. How long can you keep a book?

8. How can you renew a book?

9. What happens if you keep a book over time?

10. How should you take care of books?

11. Why should one be quiet in the library?

12. What does the Iibrarian do?

The children intended to ask the

librarlan some of these questions.

B. The trip to the Librexy:

The mothers who were going to drive

cars came to school at the appointed time. The 
children went to the cars in small groups, as had been planned the day before. They drove to the Highland Branch Library. In the Ilbrary they noticed the arrangement of the furniture, that 1s, the books, the tables, the chalrs; the card catalog, and the posters. The librarian told them about the library. She told them how the books have numbers. She told them that each book had a house number and that each book Ilved on a special street just as the children did. Some books live on Story Street, some on Star Streot, and some on Game Streot. She told them how they could take the books out and how long they could keep the books out. She showed them how to find books that second graders would enjoy. She told them how they must put the number of their cards on the card that is found in the back of the book. She read them two stories. Then she let the children look through the books on the shelves. The children were greatly Impressed with the working of the If ibrary. When 1t was time to leave, the children thanked the Iibrarian for the lovely visit. They were taken 
back to school in the cars in which they came. After every one had returned the teacher gave each child a plece of paper on which the children drew something they had seen at the Iibrary. In Figure I, the pictures and story produced by the chlldren setting forth their thoughts and ideas received from the trip are shown.

c. Discussion after trip and planning of the activities:

When the children returned from their trip they were more enthusiastic than ever about bullding their library. They composed a story about their trip which read:

The Highland Library

We went to the library this morning. The library is a big red and white building. We had to walk up many steps. The first thing we saw was many books. Miss said, "There are 2800 books in the Highland Library." She read us two stories. One story was about. "Snippy and Snappy", who were two little mice. The other story was about a dog named Michael. She told us about the cards in the library. We told M1ss Iibrary in our room. that we were going to build a

$$
\begin{aligned}
& \text { Class Story, } \\
& \text { IA-2B Class, } \\
& \text { Long fellow School. }
\end{aligned}
$$

The following day this story

appeared in printed form on a chart which likewise served as incidental reading material for the 


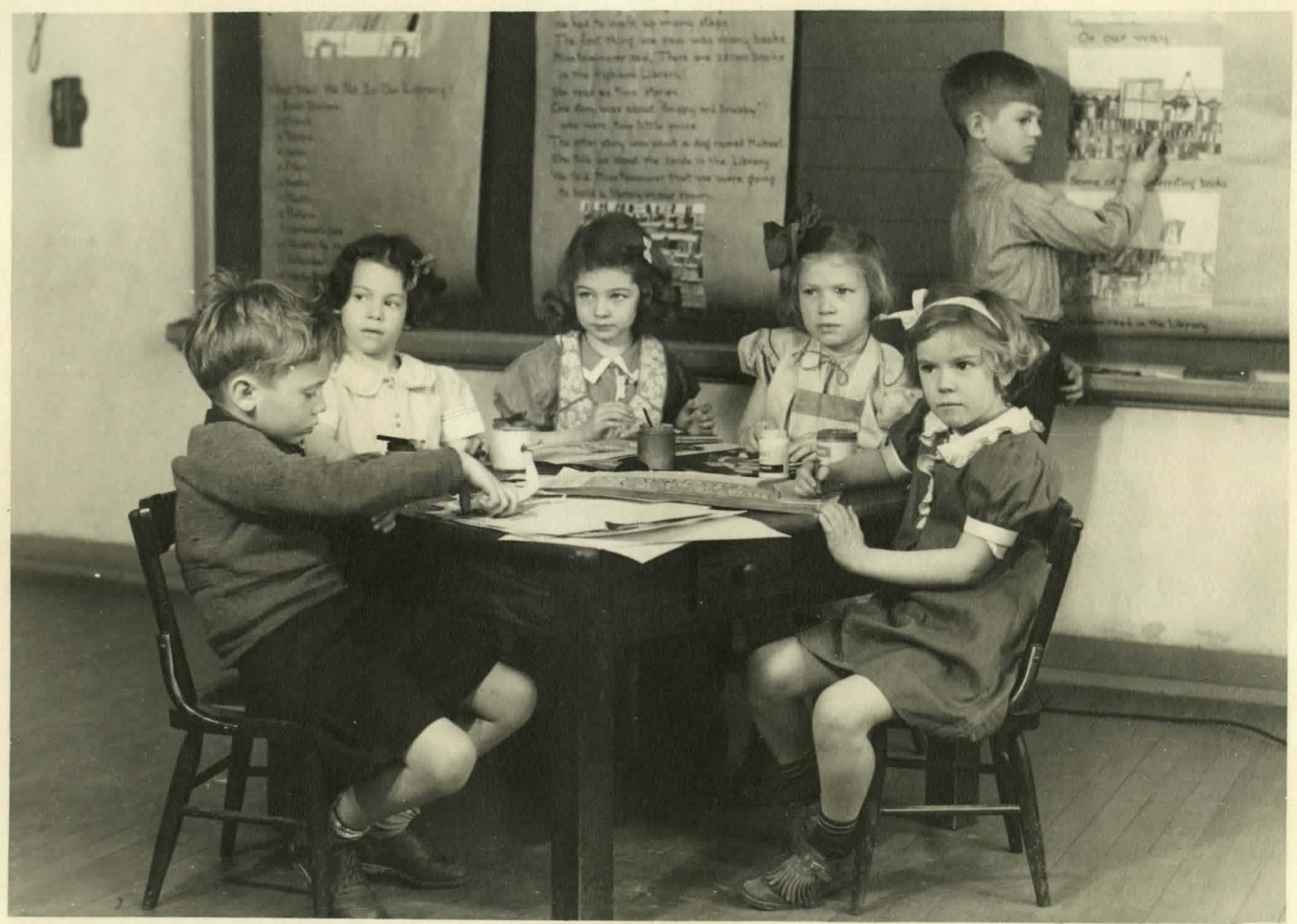

Photo By GEORGE A. RUEDEMAN

F1gure I. A group from $1 \mathrm{~A}-2 \mathrm{~B}$ Class at Longfellow School, Louisville, Ky., making posters. 
group. This chart can be seon in FlgureI. The children also discussed the things they wished to include in their library. They dictated the list to the teacher who wrote It on the blackboard and then printed it on a chart. The list included:

Book-shelves
Tables
Chairs
Cards
Flle
Plants
Books
Penc1ls

Paper welght

Posters for bulletin board Desk (librarian) Waste paper basket Calendar Pockets for cards Erasers

D. Constructing the library:

The children discussed the material. they would need to build book shelves and chalrs. The list was dictated to the teacher who wrote 1t on the blackboard and then printed it on a chart. The list included:

$\begin{array}{ll}\text { Orange crates } & \begin{array}{l}\text { Cards for catalog and } \\ \text { children's library cards } \\ \text { Paint }\end{array} \\ \text { Pancils } \\ \text { Nalls } & \text { Vases } \\ \text { Saws } & \text { Plants } \\ \text { Clips } & \text { Brushes }\end{array}$

In the next group discussion the children decided to select committe日s for each phase of work. They realized that every one could not paint; so they divided up the work between them. The committees were: 


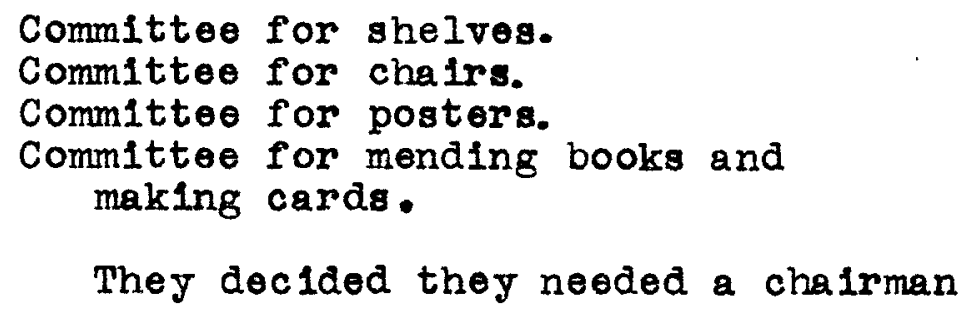

Teacher: "What does the chairman of a comittee do?"

Ch11d: "The chalrman must know how to do almost everything."

Child: "The chairman must be kind."

Child: "The chairman must have self

control."

The committees and chairmen were selected by the children. The children were now ready to work.

The following morning the children came in bubbling over with interest and entbus iasm. They came in the room with hammers, saws, nails, and aprons that they had gotten from home. They brought orange crates from the P18gly-Wiggly at the corner. They did not wait for an eightthirty bell to ring. They began to work Immediately. For the next week or so the room wes a busy workshop. The time came to paint the book-shelves and chairs - but there was no paint In the room. Immediately the children had to plan how to get paint and brushes. 
One child said, "We can get paint and brushes at the Five and Ten Cent store."

The next problem to solve was the amount of paint they should buy. After some discussion they decided to buy seven cans of enamel and seven brushes. That would give each boy who was on the paint committee a brush and a can of paint. A little girl reminded us that we could buy our file box at the same time.

The big problem was the question of money. It happened that the children had already thought about such emergencles, and had started a penny bank. They counted their money in the bank and figured out how much the items would cost. The following list was put on the blackboard:

$\begin{array}{lrr}7 \text { cans of paint } & - & .70 \\ 7 \text { brushes } & - & .70 \\ 1 \text { package of cards - } & .05 \\ 1 \text { f1le box } & - & .10 \\ 1 \text { f1le } & - & .10 \\ & & \$ 1.65 .\end{array}$

After counting their savings they found they did not have quite enough money. They decided to wait unt1l after lunch to do their shopping. After lunch they passed the penny bank to each child. Their amount increased. Then the teacher lent them the rest to make up the $\$ 1.65$. (By the end of the term all the 


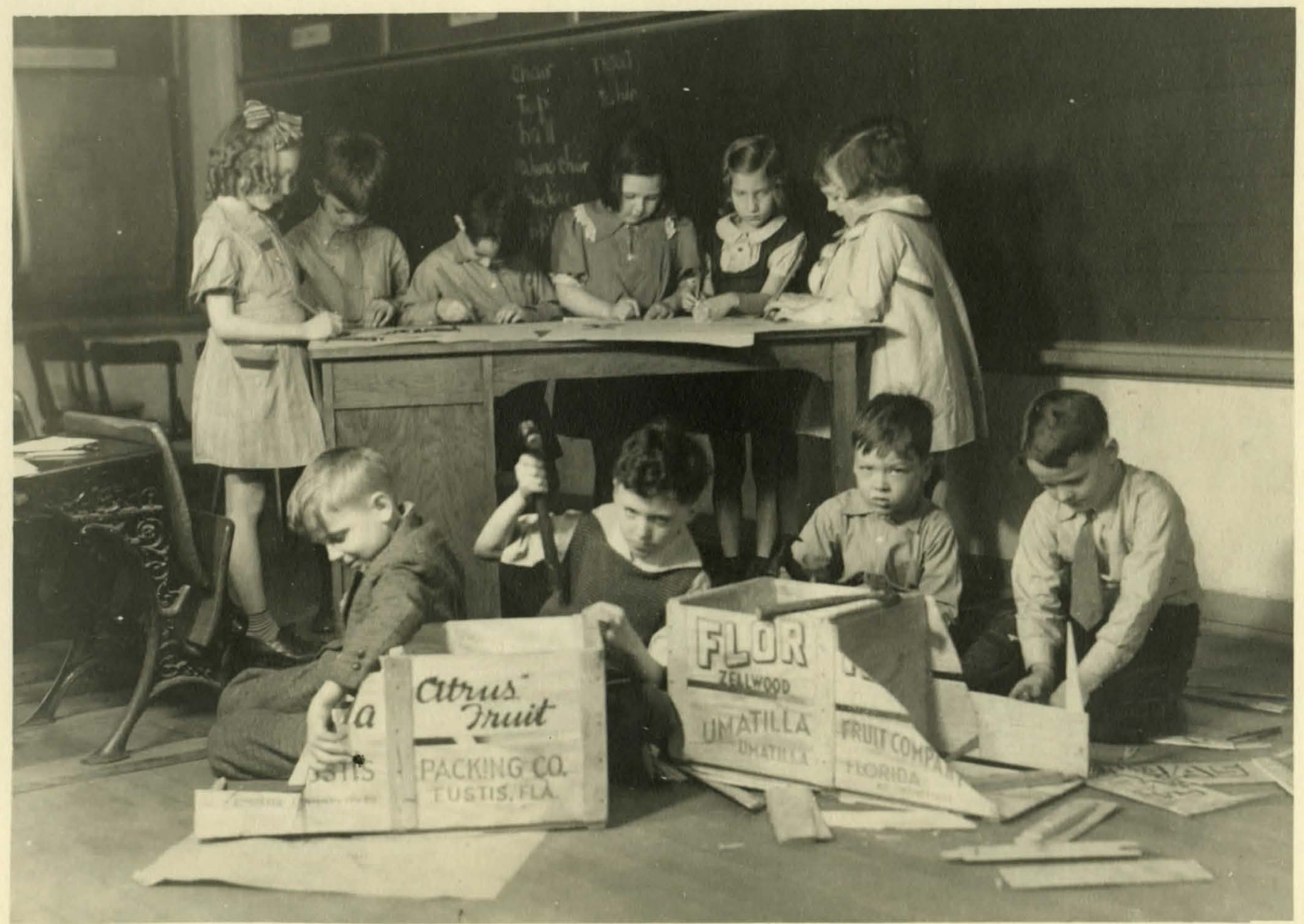

Photo By GEORGE A. RUEDEMAN

Figure II. A group from the IA-2B Class making cheirg out of orange crates. 
money lent by the teacher was repaid.) After the shopping trip to the Five and Ten Cent Store every one resumed his job and began working very hard to finish the furniture and other necessary equipment for the library. In Figure II the boys are making chairs out of orange crates. The girls are making library cards for the chlidren. In Figure III the boys are painting the book-shelves and benches for the library. The other children in the class were making posters and monding books.

The children selected the part of the room most suitable for the library. They took into consideration the size of the floor space and where they would get the proper lighting. After some discussion the majority decided upon the space in the front of the room. The children assembled the furniture and arranged it to fit the floor space. They lined the book-shelves with colored paper. They made thoir own selection from varlous colors. Because It was spring they selected yellow. This made the shelves very bright. They outfitted the librarian's desk with a flle box, boll, and penc1ls. One child suggested a calendar. Since no calerdarvajs little boy sald he would bring one on Monday. On Monday the little boy brought the calendar and one little girl brought a plant. When the spring flowers 


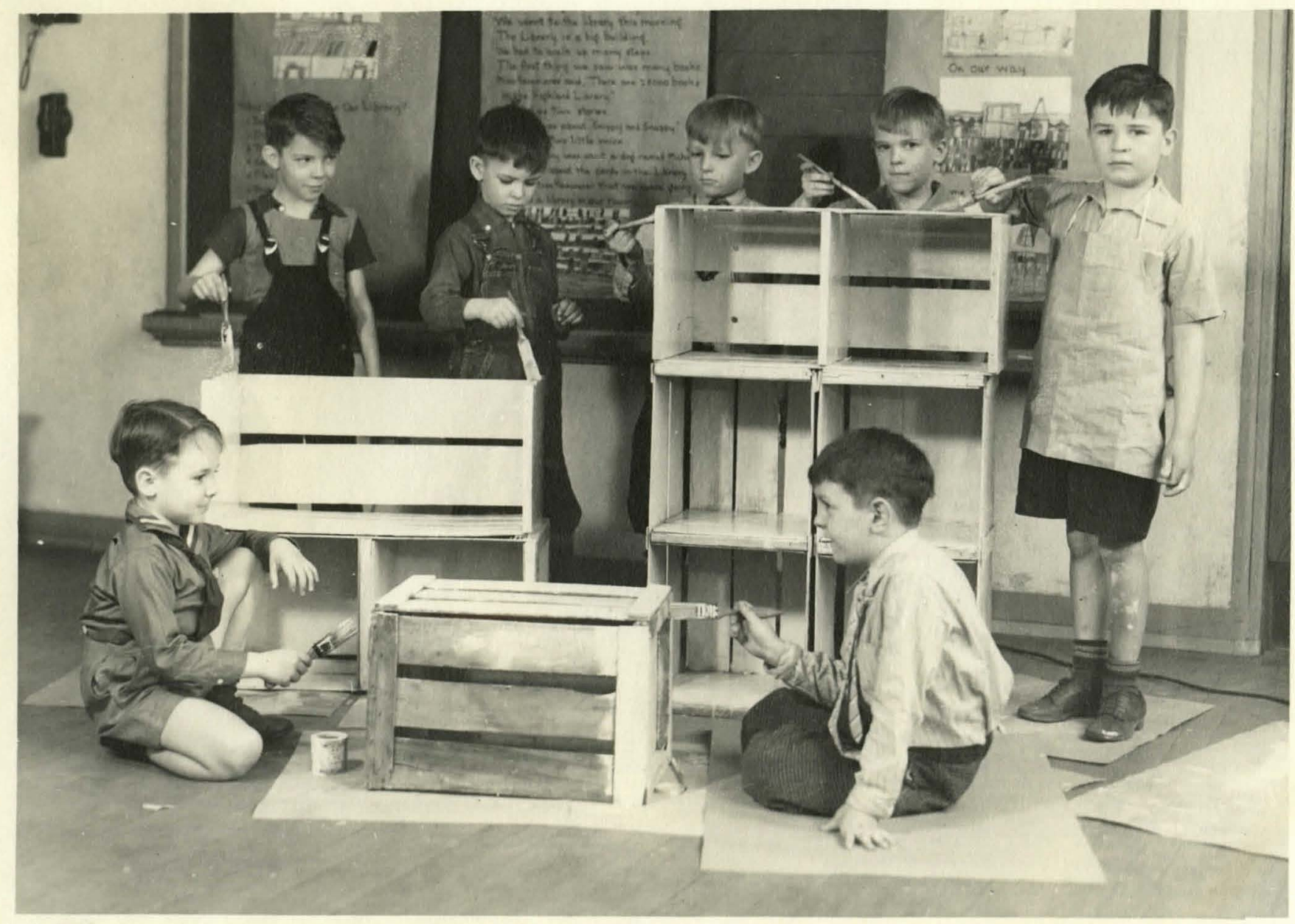

Photo By GEORGE A. RUEDEMAN

Flgure III. A group of boys from $1 \mathrm{~A}-2 \mathrm{~B}$ Class at

Longfellow School, Loulsville, Ky.,painting

book-shelves and benches for library. 
began to bloom the children brought cut flowers to make the library more cheerful.

The next step was to put the books on the shelves. The children remembered that certain books were on certain shelves at the Highland Branch Library. The librarian had told them the books lived on certain streets. The children decided to use the same idoe in classifying their books. They classified the books according to Chlldren Street, Story Street, Community Street, Animal street, and Fairy Tale street. All books containing stories about community life wero placed on the sheif named Community street. The chlldren had over a hundred books to take care of. These books came from the Highland Branch Library, the Primary Supervisor's Office at the Board of Education; supplementary books supplied by the Board of Education, the children's books brought from home, and the teacher's own collection.

The following day the teacher acted as librarian and each child selected a book he or she wished to take out for a week. Each child had his own library card and each book had a card in the back with the name of the book and author on it. When a child presented the book to the librarian the card in the book was taken out and the number of the child's card and the date due werefwitten on the card. This card was placed in the file book. Then the date on which 
the book was due was written on the child's Ilbrary card and slipped in the pocket of the book. Not everyone got a book the first day. A child acted as librarian (with a little holp from the teacher) for the rest of the children. After the books were out a week the children could renew them if they had not finished reading them. If they forgot to renew the book they paid a penny fine. When a child finished reading a book he reported on the book to the rest of the class. Some chizdren read a story from a book, sone read parts of a story, some told a story, and some would have questions prepared to ask after reading or telling their story. This told the person reporting/ the rest of the chlidren in the class were good listeners. A large chart was also hung in the room and each book the chlldren read was recorded on this chart. In Figure IV, the completed library is shown. The blackboard on the left hand wall shows the large chart on which the names of the books were recorded that each child had read. This unit functioned throughout the semester keeping its interest until the end. It served as a help during other units when the children nooded factual knowledge about the dry goods store, post office, or dairy farm. The children took care of the books and of the library. It was their duty to see that the books were on the 
Flgure IV shows completed library.

Photo By GEORGE A. RUEDEMAN

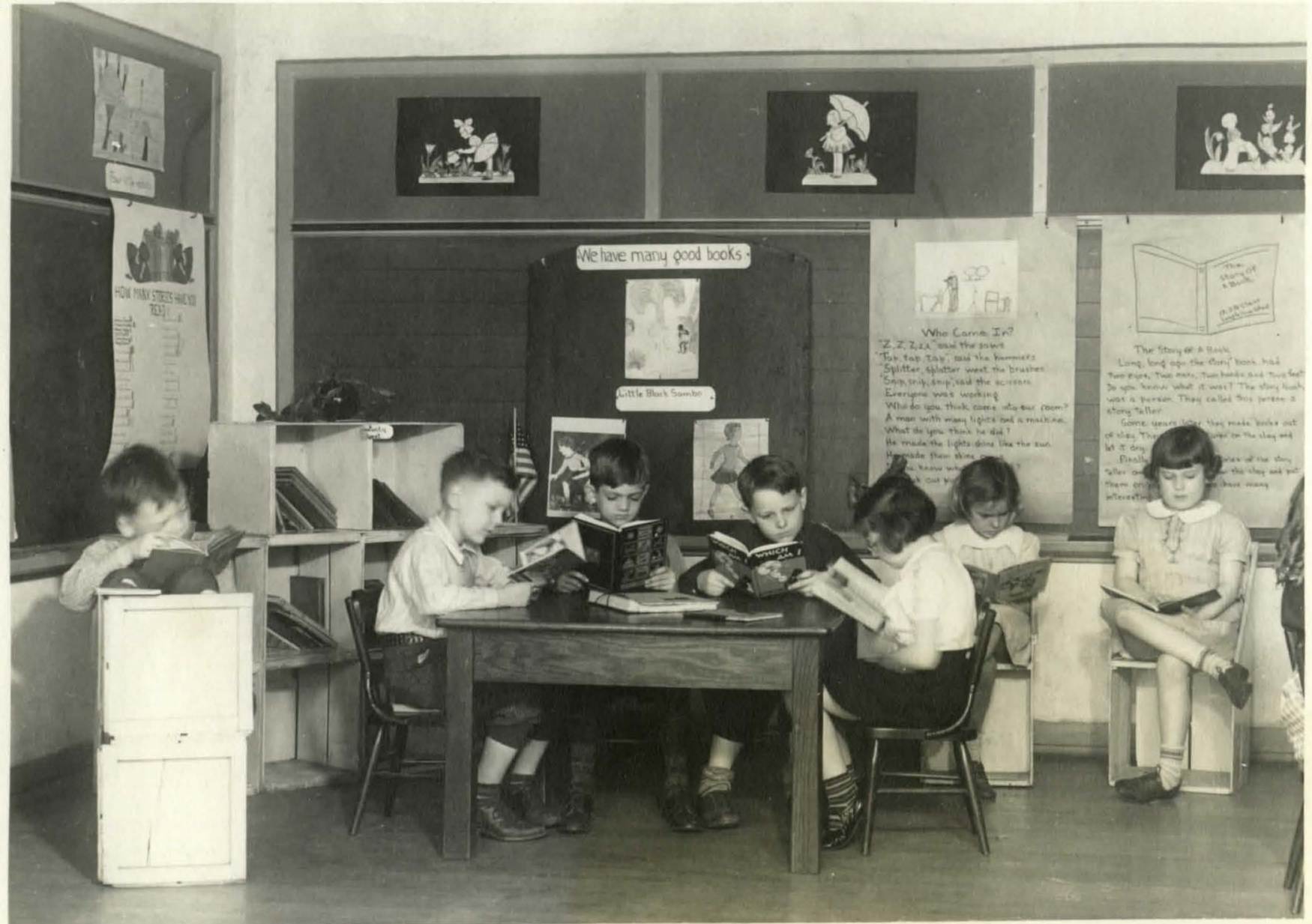




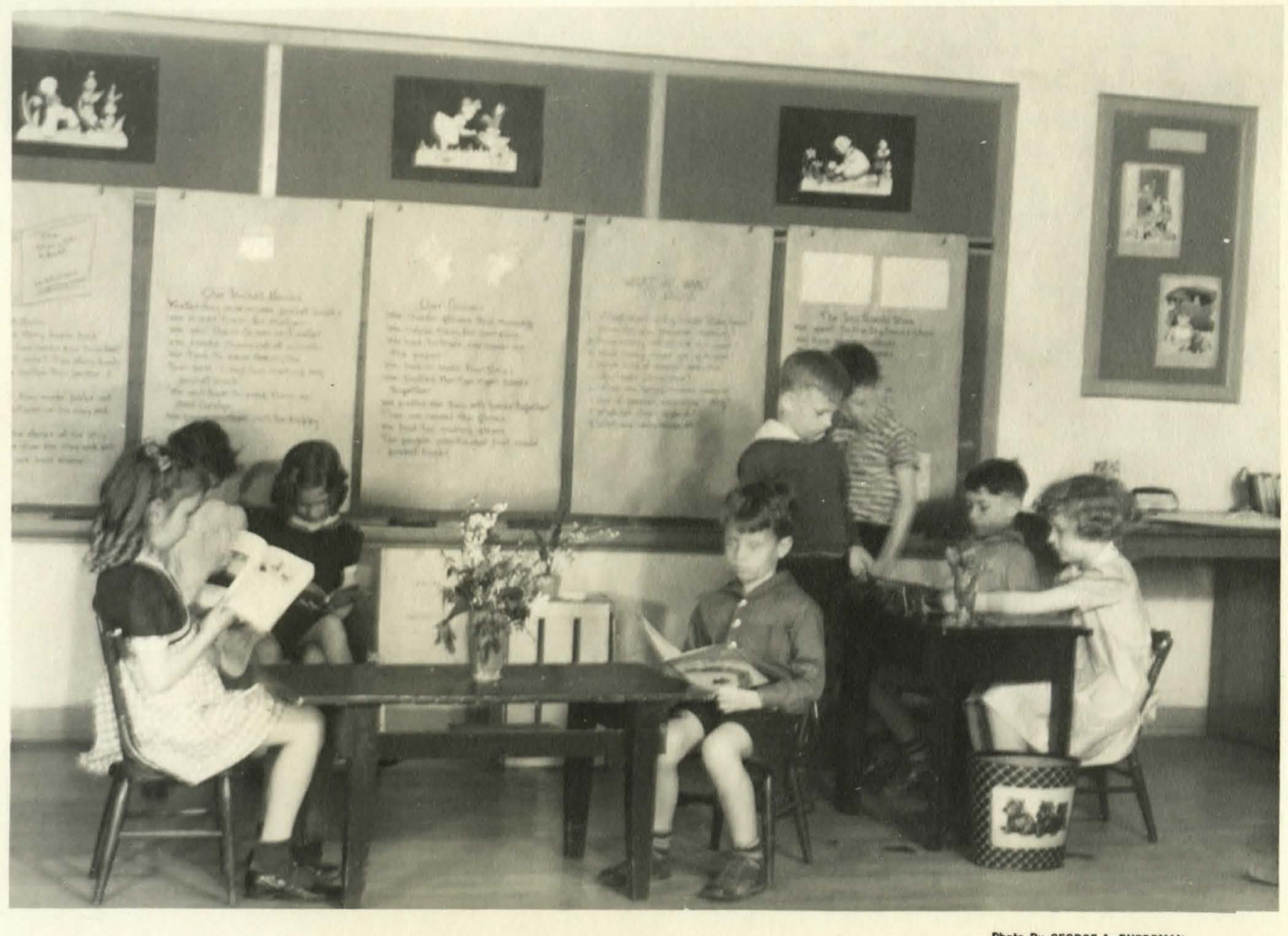

Figure IV shows completed library. 
correct shelf. During one of the Safety Counc1l Moetings a committer of two was selected to take care of the library. When the library was completed a test of one hundred questions was given. This test is given in full detail later in this discussion. The preceding pages have given a detalled record of the library unit including the approach and procedure of teaching. The following pages give the objectives, subject matter, outcomes, tests, and books used.

II. Objectives:

A. General Objectives - (Teacher's)

1. To stimulate a greater interest in books.

2. To teach children how to use the library properly and

inteliigentiy.

3. To provide opportunities for self-expression in art,writing, prose, poetry, and dramatization.

4. To develop a love for the besutiful things in literature and art.

5. To create an atmosphere in which the children will be very happy with books and pictures.

6. To develop attitudes of holpfulness, cooperation, carefulness, and appreclation of the work of the members of the group.

7. To place emphasis on the Ilbrary as a source from whlch books may be obtained, for factual materlal as well as enjoyment. 
8. To teach economic and effective habits, and skills in the use of books.

9. To teach a respect for books and develop habits of taking caro of them.

10. To encourage pupils to bring to class books, magazines, and pictures.

B. Specific Objectives - (Teacher's)

1. To give the child the knowledge of how to use a book.

- (a) Use the table of contents.

(b) Be able to recognize a paragraph.

2. To teach the child how to care for books. (See Learn to Study Reader, Book I, page 14; pp. 30-31)

(a) Turn pages carefuliy.

(b) Use book marker.

(c) Mend pages.

3. To give children an index to the best books that may be secured.

4. To encourage good reading habits.

(a) "Ifving in the Content"; emphasis a Iways on understanding and appreciating what has been read.

(b) Reading fluentiy and rapidiy with a ateady effort to increase the eyo span, shorten the perlod of fixation, and insure a rhythmical eye movement; rapid recognition.

(c) Reading with little or no pointing, vocalization, or lip movement.

(d) Ifstening courteously and interestediy when others are reading.

(e) Asking questions about parts of the content which are not understood. 
(f) Seeking and giving help when needed.

(g) Handling the book deftly and carefully.

(h) Reading silently and becoming familiar with the material before reading orally.

5. To inform the child of the library nearest the child's home.

(a) Highland Branch Library, 1000 Cherokee Road.

C. Children's Objectives-

1. To visit a liorary.

2. To secure a library card.

3. To get books from the library.

(a) To know where to find the different types of books, as Fairy Tales and Anlmal Storles.

4. To build a library in the room.

(a) Have a Iibrarian.

(b) Borrow books.

(c) Stamp cards.

(d) Make story and plcture books to bo used in the Iibrary.

5. To play going to the library.

6. To hear some new storles.

7. To tell stories they have read to classmates, to other classes, or at home.

III. Subject Matter:

The subject matter of an activity

program is an integrated program - not separate subjects. The subject matter of an activity program $-104-$ 
meets the activity interests of children - subject matter which is stimulating and rich in content and which Identifies the child with soclal situations. This unit on the library embraced many child experiences. These experiences brought in a noed for reading, arithmetic, spelling, language, writing, safety, health, nature, art, and industrial art. Each of these subjects will be taken up separately.

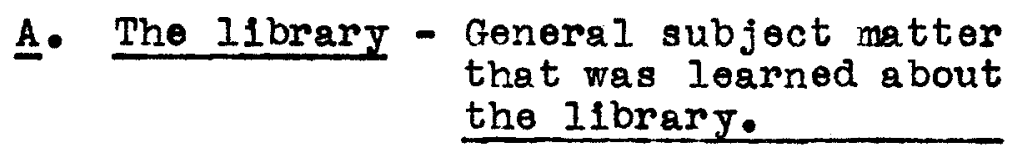

1. How to secure an application card.

2. How to secure a library card.

3. How to get a book desired.

(a) Know the author.

(b) Look at the numbers on the book and shelf.

(c) Ask the librarian.

4. How long books should be kept. (Understanding of dates on the card.)

5. How to renew books.

6. Amount of fine if books are overdue.

7. Care of books.

8. Necessity of being quiet in the library.

9. Use of tables and chairs in the Iibrary.

10. The work of the Ilbrarian.

(a) Recelve books and stamp them.

(b) Give new applicants library cards. 
(c) Stamp outgoing cards.

(d) Keep order in the I1brary.

(e) Keep the books stamped to date, and flied on the proper shelves.

(f) Know the authors of the books.

(g) Tell storles during story hour.

11. Where do all the books come from?

(a) Secured by purchase.

(b) Donated by someone.

12. Attention to the furniture, pictures, and plants.

B. From the study of the 11brary the children found a need for the following activities in the varlous subjects. These activities are listed briefly. In this way they will be/ easily read and understood.

I. Reading:

(a) Reading of the bulletin board.

1. New pictures with or without short story attached.

2. New pictures with a statement about the picture.

3. Best work or improved work.

4. Notices for the ensuing dey.

5. Pictures for appreciation and original story teliling.

5. The chart giving the record of the books each child had read.

(b) The children made sneclal library books, the content of which was 
original stories contalning the work with which they became familiar in their study.

(c) They formulated stories of their trips to the library and the Five and Ten Cent Store. All stories written by the children wore printed on a large chart and hung in the room for each child to seo and read.

(d) The reading of poems and storles by the ohtldren.

(e) Reading the inscriptions under the pletures drawn and named by the children.

II. Ar1thmetic:

(a) Counting by 1 is to 150 .

1. Finding the pages of the story to be read.

2. The number of books on the library table.

3. The number of books to be distributed among the children.

4. The number of children who have library cards.

(b) Addition.

1. In classifying the books for the library the children wanted to know how many books were in each class and then how many 
books they had in the library. They added the number of books on Children Street, on Story Street, on Commanity Streot, Animal Streot, and Fairy Talo Streot.

20 Children streot

15 Community Street

35 Story Streot

15 Animal Stroot

1 Falry Tale Street

86 Books in the library.

2. Adding the number of wild animal storles, pet storles, our helper stories, holiday storles, adventure stories and hoalth stories found in one book.

2 health stories

4 wild animal stories

3 our helper storles

2 adventure tories

6 pet stories

17 storles in the book.

3. Adding the money spent to make the library.

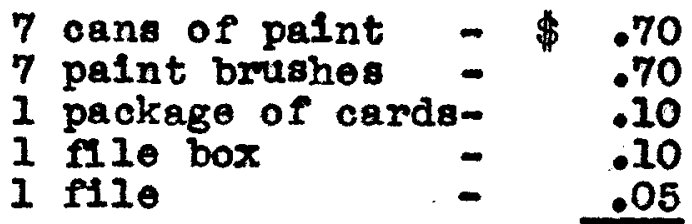

Cost of material

for library - \$1.65

(o) Subtraction.

1. Subtracting the number of pages

In a book that the child has

read from the total number of pages in the book, to flnd how many more pages he must read in order to finish the book. 
(d) Value of money.

1. Cost of a book - 10ф; 25 ; 50 ; $75 \% ; \$ 1.00$; $\$ 1.50$, and $\$ 2.00$.

Value and use of the penny bank.

1. How to spend the money.

Value of money when golng on a shopping trip.

(e) Thought problems.

1. John returned two books to the library. He borrowed 4 books. How many more books did he borrow than he returned?

2. We have 6 ploture books on our library table and 9 story books. How many books do we have?

3. There are 10 stories in the book. You have read 6 of them. How many more have you to read?

4. Mary has 2 stacks of library cards. There are 10 cards in one stack. and 10 cards in the other stack. How many cards has Mary?

5. Tom Iikes animal stories, Jano likes stories about dolis. Tom read 5 storles and Jane read 7 stories. Who read the more stories? How many more?

6. Jane goes to the FIve and Ten Cent Store to buy a book. She has 15\%. The book entitied, "What Am I?" costs 10 6 . DId she have any money left? How much?

7. If 1 can of paint cost 10\%, how much will 7 cans of paint cost? 
8. Experience with calendar. Finding the date on which a child takes a book from the I1brary, then determining when the book is due. If a fine of If a day is charged for overdue books, how much w11 have to be paid if a book is kept 4 days overtime?

III. Speliing:

(a) Subject matter.

$\begin{array}{llll}\text { date } & \text { table } & \text { title } & \text { poom } \\ \text { write } & \text { books } & \text { eraser } & \text { Iibrary } \\ \text { name } & \text { read } & \text { mumber } & \text { flx } \\ \text { color } & \text { careful } & \text { clean } & \text { content } \\ \text { pencil } & \text { pages } & \text { hands } & \text { step } \\ \text { white } & \text { tell } & \text { neat } & \text { dirty } \\ \text { silence } & \text { ink } & \text { turn } & \text { paper } \\ \text { quiet } & \text { tear } & \text { story } & \text { pen } \\ \text { chairs } & \text { crajon } & \text { new } & \text { windor } \\ \text { book } & \text { shelves } & \text { flne } & \text { cost } \\ \text { Interesting pages } & \text { renew } & \text { calendar } \\ \text { librarian } & \text { enjoy } & \text { long } & \text { shelf } \\ \text { card } & \text { author } & \text { care } & \text { overdue }\end{array}$

(b) Speliling seat-work。

1. Fill in the blanks with spelling words.

We went to the

We saw many

It was very

The

We turned the

helped us choose

The shelves are IIIIOd with

2. Divide your paper into two inch spaces.

In the first space print $A$.

In the second space print $B$.

In the third space print $C$.

In the fourth space print $D$.

Onder A write five words which begin with 2 . 
Under B write six words which begin with $b$.

Under $c$ write ten words which begin with o.

Under D write seven words which begin with $d$.

This will be the beginning of a dietionary. The same is to be done with the remaining letters of the alphabet.

IV. Writing:

This unit calls for many written lessons about such topics as:

(a) What we saw on the way to the Iibrary.

(b) The librarian.

(c) new book.

(d) Book reports.

(o) Invitations to seo our new library corner. (Written to other classes in the school or the librarian at the public library.)

(f) Writing and applying spolling words in oaptions and storles.

(B) Ietter to the 11 brarian of the public 11 brary asking if the class can visit the ilbrary.

Letter to mother asking her permission to go to the 11 brary. 
Letter to the I1brarian of the public library thanking her for lotting the class visit the 11 brary.

Sample of letters.

Louisville, Kentucky February 24, 1937

Dear Miss

We would like to bulld a library in our room. We would like to come to see the library before we bulld ours. When could we come?

Yours truly,

Second Grade, Longfellow School.

Louisville, Kentucky Fobruary 26, 1937

Dear Mother:

May I go to the H1ghland Ilbrary on Tuesday with Miss ? Please sign yes or no for me.

Yours truly,

Martha.

\section{Language:}

(a) Oral language.

1. Class discussion before the visit 
to the Iibrary. (A 11st of questions was made that the class hoped to answer after the trip. These are 11 sted under "Written Language .)

2. Class discussion after visit to the 11brary. (Each question was discussed from the chart.)

3. Planning a library for the room. (Iisting the materials neoded on a chart.)

4. Reproducing storles read.

5. Telling original storles.

6. Reports on books read and atorles read.

(b) Written language.

1. The following is a list of questions made by the class. These questions were to be answered through the help of the librarian, and observation upon the visit to the library.

Who owns the library?

Where does the library get the books?

Who goes to the library?

How can the class make a library?

What should go in the library?

How much do books cost?

How long can you keep a book?

How can you renew a book?

What happens if you keop a book overtime?

How should one take care of books?

Why should one be quiet in the 
What does the librarian do?

How do you know where to find a certain book?

How do you borrow Ilbrary booka?

What must you do before you get

a card?

2. Library Rules. (Printed on charts)

How we shall act.

(a) Should be quiet.

(b) Be careful with books.

(c) Read to yourself.

(d) Koop chairs stili.

Care of books.

(a) Turn pages carefully.

(b) Koop books clean.

(c) Keep books on the right shelf.

3. Stories written by children.

Our Trip to the Highland Library.

We went to the library this morning. The 11 brary is a big red bullding. We had to walk up many steps. The flrst thing we saw. was many books. M1ss sald, "There are 2800 books in the Hightand Library. She read us two stories. One story was about "Snippy and Snappy" who were two little mice. The other story was about a dog named M1cheel. Sho told us about the cards in the library. We told Miss build a library in our room.

\section{Tho Came In?}

"Z Z Z ; sai d the saws.

"Tap, tap, tap i sald the hammers.

"Spiltter, spletter " went the brushes.

"Snip, snip, snip "said the scissors. Everyone was working.

Who do you think came into our room? 
A man with many 1 ights and a machine. What do you think he did?

He made the lights shine like the sun.

He made them shine on us.

Do you know what happened?

Click, he took our plcture.

The story of A Book.

Long, long ago the story book had two eyes, two ears, two hands and two feet. Do you know what it was?

The story book was a person.

This person was called a story teller.

Some joars later they made books from clay.

They drew plotures on the clay and let it dry.

Finaliy, they took the storles of the story teller and the pictures from the clay and put them on paper.

Now we have many interesting books.

VI. Health:

(a) Postrise

1. Iesirability os correct posture while sitting and standing.

2. Correct reading position with reference to 11 ght and to distance of book from eyes. (See Heal th Storles Book I, by Towse and Gray, "How to Take Care of Your Eyes"; p.41)

(b) Good Food. References to characteristics of people and things in books.

1. The children in the stories we read, eat the food that will make them strong. The children reading the stories will have a desire to follow the same example.

2. Gray Kitten 11kes milk.

3. The Three Bears eat porridge; that 1 s good for children's breakfast. 
4. The Indians eat food they find growing in the ground, on trees and bushes. That is why they are strong.

(c) Cleanliness.

1. Clean books are the most pleasant ones to read. They last the longest. Fut clean books where they will show. Dust the library furniture.

2. Hands must be clean when books are handled. Do not molsten the fingers when turning pages.

(d) Exercise and fresh air.

1. The little people in the stories I1ke to run, skip, and jump out of doors. They know the health game.

2. When roading find a nice, cool, shady place outside and take the book there. The alr helps to make our book more enjoyable.

\section{Safety:}

(a) Reading and following the rules of the "Safety Nows" bullet1n.

(b) In constructing the Ilbrary it was urged that carefulness is always best when handling saws, hammers, nails, and boards. Hammers are meant to hit nails, not fingers.

(c) Nails are not left sticking in boards, They are pulled out and the boards are put away where they will not be stumbled over.

(d) The excursion to the library gave a fine chance to discuss and play "Safety First on the Street :"

1. Getting in and out of the cars.

2. Watching traffic lights and oboying them.

3. Looking both ways before crossing the street. 
VIII. Nature:

(a) Care was taken of goldfish, remembering to keep them out of the sun, except early in the morning.

(b) Care was taken of plants and flowers in the room.

(a) Stories about the habits of animals.

(d) Directions for planting flowers.

DX. Art: (Applied in as practical a manner $a 8$ possible; a library should be an attractive place.)

(a) Dosign book covers and book marks.

(b) Draw plctures of books arranged singly or in groups.

(c) Draw pictures of the library nearest the chlld's home.

(d) Draw pictures of the library visited by the children.

(e) Draw a plan of how each child would like for the classroom library to look after it is completed.

(f) Draw plctures of shelves of books.

(g) Figure drawing.

1. A chlld reading alone.

2. Children reading in a group.

3. Children at the Iibrary table.

(h) Illustrate storles read by the children.

(1) Make a booklet of their "Trip to the Library : or of the things they did while making their library. 
X. Industrial Art:

(a) Construction of a library in the room.

1. Book shelves made from orange crates.

2. Chasrs and benches made from orange crates.

3. Library cards made from tag board.

4. Posters for bulletin board.

5. Board borders.

6. Book containing stories and plctures about the unit.

XI. Music:

An interest in enimals, birds, children, and seasons was deepened as the children learned and read more about these subjects. The song material was taken from the second grade outline in the Course of Study in Music for the Louisvilie Public Schools.

\section{Test:}

An objective test of ill questions was given to the group at the end of six weeks. The rellability of this test using the

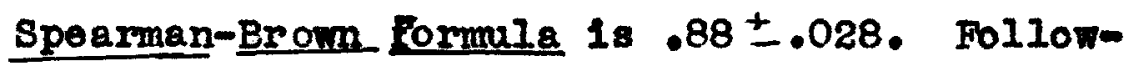
Ing is a copy of the test given. Completion:

Directions: Read the sentence and put the right word in the blank space.

Examples: (a) The library should bo very quilet. 
(b) The Three Bears went for a walk.

1. The library is a good place to

2.. The library should be

3. Sometimes you can hoar at the Ilbrary.

4. You must have a the $11 \mathrm{brary}$. to get a book from

5. You may keep your book for weeks.

6. The library has many tables and

7. You may your book if you have not. finished reading it in two weeks.

8. You should turn the pages of a book

9. To find a story in a book you should use the of

10. The person who takes care of the I1brary 1s callod a

11. If you want a certain book you must know the of the book and the

12. If a book 1s overdue you must pay a

13. You should keep library books

14. We get from the library.

15. Little grandmo ther. went to ser her

16. The little old baked a Gingerbread Boy.

17. The ate the Gingerbread Boy.

18. visited the home of the Three Bears.

19. Baby chair was broken when he came home.

20. The helps you choose good books.

21. The shelves at the library are filled with many good

22. An writes books. 
Word Recognition:

Directions: Draw a line under every word that means only one.

Examples: (a) stiok pens pig cogs

1. bird - frogs - bearg - desk - sky

2. cooks - library - dog - cats - bears

3. chairs - table - store - boy - boats

4. stories - story - word - words - toy

5. ch1ld - wolf - bears - pony - horses

6. chair - shelf - girl - boys - words

7. children - house - flower - books - cat

8. Ilbrarlan - card - shelves - dogs - car

9. mouse - mice - elephant - camels - book

10. dosk - girls - floors - pages - pago

True or False:

Directions: Road the sentence; if it is right; write yes by the number; if the sentence is wrong; write no by the number.

Example: No. 1. Boys can bark.

Yes. 2. Girls can sing.

1. Little Boy Blue went up the hill.

2. The library is a place to read.

3. Anyone may take a book from the library if he has a card.

4. Only people who have a card may read books in the 11 brary.

5. The library is open only on Sunday. 
6. You may keep any book for three weeks.

7. Goldilocks visited the home of the Three Bears.

8. The Gingerbread Boy ran away from the little old woman and the little old man.

9. To find a certain book you must know the page number.

10. Always turn the pages of a book carefuliy .

11. The library is a place to talk.

12. An author writes letters.

13. To find a certain story you should use the table of contents.

14. A book may be taken from the library for two weeks.

15. Books cannot be renewed.

16. The person who is in charge of the library is called the librarian.

17. Goldilocks broke Father Bear's bed when she tried it out.

18. Goldilocks broke Mother Bear's chalr when she sat in 1 t.

19. When you are in the I1brary you should be very quiet.

20. To take a book from the library you must have a card.

21. You may renew your books over the telephone, if you can give the librarian the number and name of your book.

22. You may buy books at the Iibrary.

23. Very few people go to the library.

24. The library has only story books.

25. The library has many magazines. 


\section{Opposites:}

Directions: Cross out the word that does

not belong in the Iine.

Examples: pretty ugly watk-

run fump- walk

\begin{tabular}{|c|c|c|c|}
\hline 1. & happy & now & unbappy \\
\hline 2 & $\operatorname{col} d$ & warm & hot \\
\hline 3. & come & run & waIk \\
\hline 4. & bird & wet & $d \mathbf{r y}$ \\
\hline 5. & dirty & books & clean \\
\hline 6. & glad & $\operatorname{sad}$ & glove \\
\hline 7. & boy & house & girl \\
\hline 8. & light & lamp & dark \\
\hline 9. & black & blue & white \\
\hline 10. & night & went & day \\
\hline 11. & up & down & run \\
\hline 12. & $\operatorname{com} \theta$ & white & go \\
\hline 13. & arm & new & old \\
\hline 14. & $l \in f t$ & hand & right \\
\hline 15. & came & back & front \\
\hline 16. & hot & love & hate \\
\hline 17. & right & wrong & $\mathbf{s e \theta}$ \\
\hline 18. & from & under & over \\
\hline 19. & lato & some & early \\
\hline 20. & far & near & box \\
\hline 21. & for & few & $\operatorname{man} y$ \\
\hline 22. & long & saw & short \\
\hline
\end{tabular}




$\begin{array}{llll}\text { 23. buy } & \text { by } & \text { sell } \\ \text { 24. pleasant } & \text { go } & \text { unpleasant } \\ \text { 25. come } & \text { go } & \text { run }\end{array}$

Word Recognition:

Directions: If these words are the same put an $S$ on the dotted 11ne; If they are different put a $D$ on the dotted line.

Example: bird -..-S_... bird

\begin{tabular}{|c|c|c|c|c|c|c|}
\hline 1. & run - & $------n$ & - run & 16. & band. & $-\ldots-\ldots$ band \\
\hline 2 & fly & $----\infty-\infty$ & - flies & 17 . & land & -----1 land \\
\hline 3. & come & ------- & - came & 18. & $\operatorname{se11}$ & $-\ldots-\cdots-\operatorname{man}$ \\
\hline 4. & for & $-\infty-\infty-\infty$ & - for & 19 & boy & $-\infty-\infty-\operatorname{glr} I$ \\
\hline 5. & wait & $------n$ & wa1t & 20 & $\operatorname{ear} 1 \mathrm{y}$ & $-\infty-\infty \operatorname{early}$ \\
\hline 6. & want & $-\cdots---$ & went & 21. & bad & $-\infty-\infty$ bad \\
\hline 7. & tries & $-\infty-\infty-\infty$ & tries & 22 & $s e \theta-$ & $\cdots-\infty-\infty \theta$ \\
\hline 8. & bird & $-----\infty$ & cat & 23 & were & $-\infty--\infty$ where \\
\hline 9 & waIk & $-\infty-\infty$ & walk & 24 & $2 \mathrm{~m}$ & $-\infty-\infty$ am \\
\hline 10 & seen & $-\infty-\infty-\infty$ & seem & 25 & saw & $-\infty-\infty-\mathbf{s a w}$ \\
\hline 11. & day & $---\infty$ & da ys & 26 & $\operatorname{can}-$ & $-\ldots-$ and \\
\hline 12 & many & $-\infty-\infty-\infty$ & $\operatorname{man}$ & 27 & book & $-----\infty$ pqge \\
\hline 13 & from & $-\infty-\infty$ & from & 28. & books & $--\infty-$ books \\
\hline 14 & near & $----\infty$ & near & 29 & went & $-\infty-80$ \\
\hline 15. & call & $-\infty-\infty$ & cal1 & 30 & page & $\ldots-\infty$ page \\
\hline
\end{tabular}




\section{Matching:}

Directions: Draw a line from the picture to the right word.

Example:

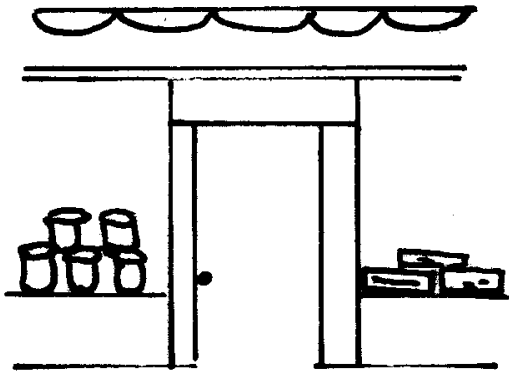

8
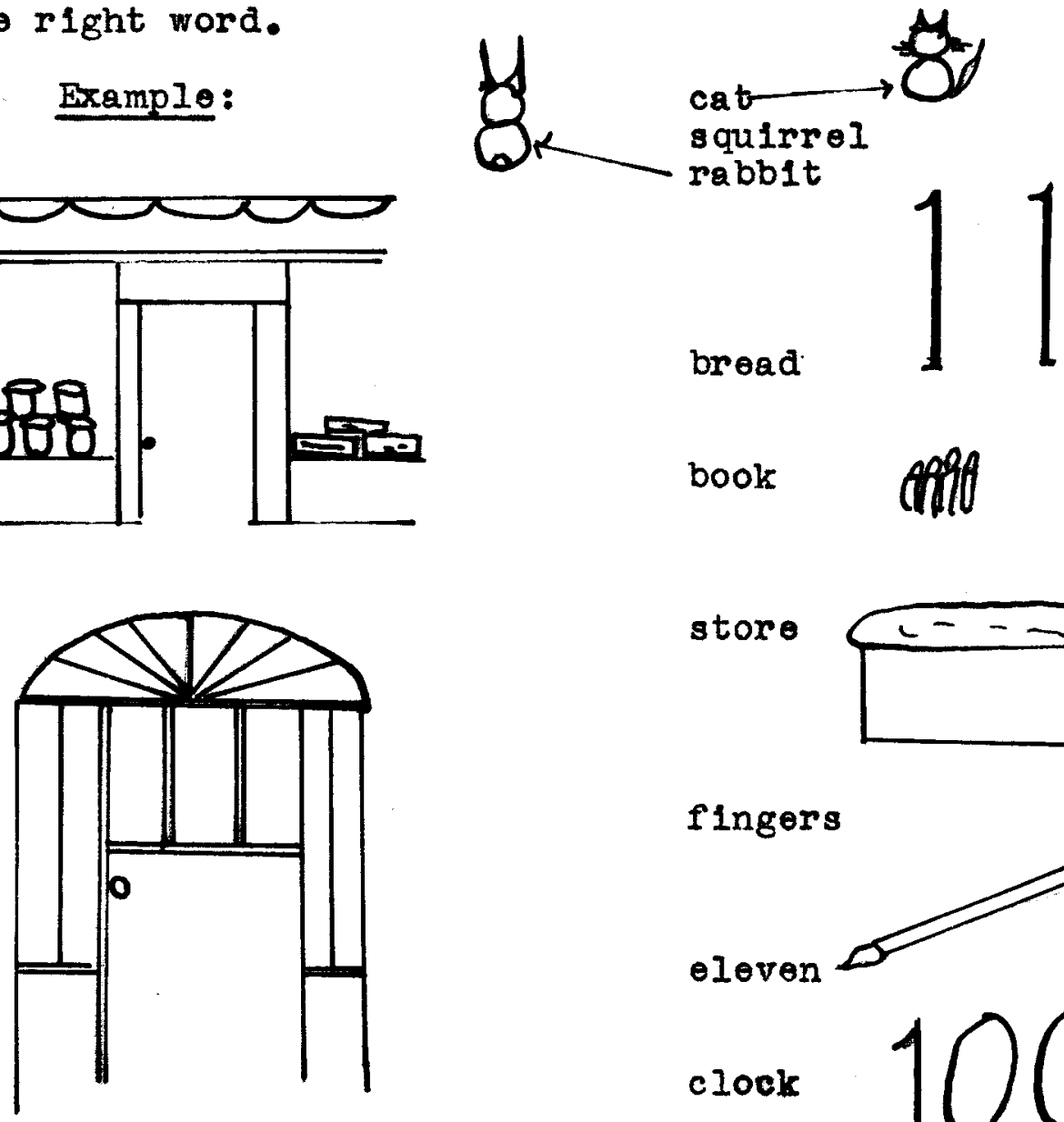

store

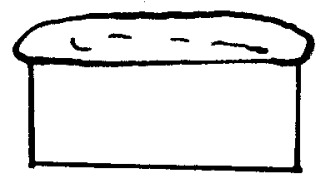

fingers
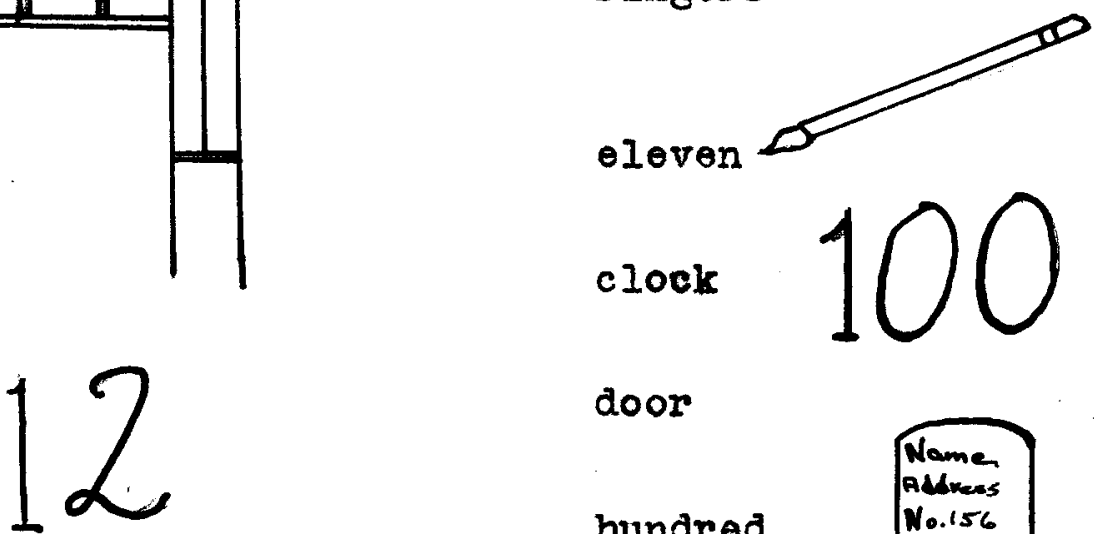

door

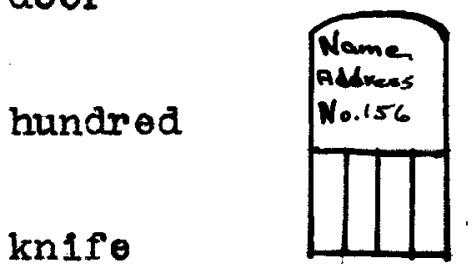

card
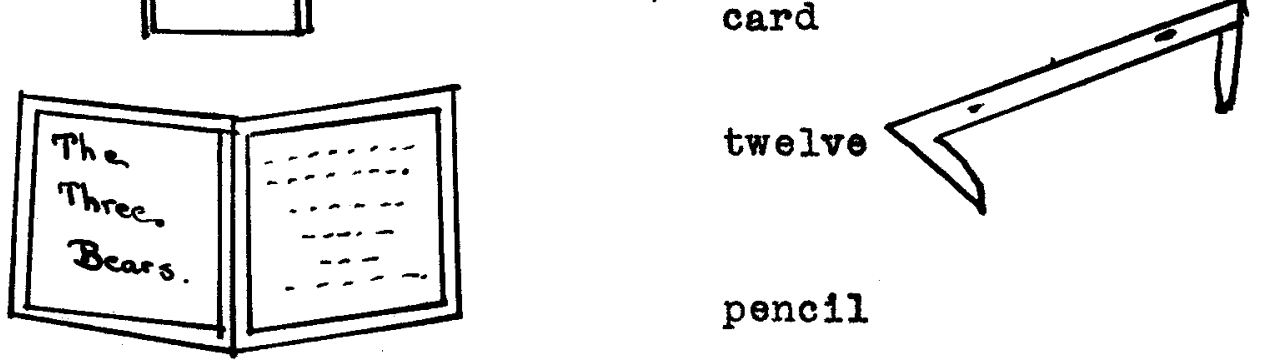

penc1l 


\section{Key for questions on the Library}

\begin{tabular}{|c|c|c|}
\hline Completion & Word Recogn1tion & or False \\
\hline 1. read & 1. bird, desk, sky & 1. No \\
\hline 2. quiet & 2. Iibrary, dog & 2. Yes \\
\hline 3. stories & 3. table, store,boy & 3. Yes \\
\hline 4. $\operatorname{card}$ & 4. story,word,toy & 4. No \\
\hline 5. two & 5. child,wolf, pony & 5. No \\
\hline 6. chaira & 6. chair, shelf,girl & 6. No \\
\hline 7. renew & 7. house, flower, cat & 7. Yes \\
\hline 8. carefuliy & 8. Ilbrarlan, card,car & 8. Yes \\
\hline 9. table, content & 9. mouse, elephant, book & 9. No \\
\hline 10. I1brarian & 10. desk, cha ir, page & 10. Yes \\
\hline 11. name, author & & 11. No \\
\hline 12. $f \ln \theta$ & & 12. No \\
\hline 13. clean & & 13. Yes \\
\hline 14. books & & 14. Yes \\
\hline 15. Red Riding Hooc & & 15. No \\
\hline 16. woman & & 16. Yes \\
\hline 17. wolf & & 17. No \\
\hline 18. Goldilocks & & 18. No \\
\hline 19. bear & & 19. Yes \\
\hline 20. 11brarian & & 20. Yes \\
\hline 21. books & & 21. Yes \\
\hline 22. author & & 22. No \\
\hline & & 23. No \\
\hline & & 24. No \\
\hline & & 25. Yes \\
\hline
\end{tabular}




\begin{tabular}{|c|c|c|}
\hline Oppos1tes & $\begin{array}{l}\text { Word Recognition } \\
\mathbf{S}-\text { Seme } \\
\text { D - Different }\end{array}$ & Matching \\
\hline 1. new & 1. $\mathrm{s}$ & bread \\
\hline 2. warm & 2. & book \\
\hline 3. bird & 3. & store \\
\hline 4. $\operatorname{com} \theta$ & 4 & finger \\
\hline 5. book & 5. & eleven \\
\hline 6. glove & 6. & clock \\
\hline 7. house & 7. $s$ & door \\
\hline 8. Iamp & 8. & hundred \\
\hline 9. blue & 9. & knife \\
\hline 10. went & 10. D & card \\
\hline 11. run & II. D & twelve \\
\hline 12. white & 12. D & penc1l \\
\hline 13. $\operatorname{arm}$ & 13. $\mathrm{s}$ & \\
\hline 14. hand & 14. $\mathbf{S}$ & \\
\hline 15. came & 15. $\mathrm{s}$ & \\
\hline 16. hat & 16. $\mathrm{s}$ & \\
\hline 17. 800 & 17. s & \\
\hline 18. from & 18. D & \\
\hline 19. some & 19. & \\
\hline 20. box & 20. $\mathrm{s}$ & \\
\hline 21. for & 21. & \\
\hline 22. saw & 22 . & \\
\hline 23. by & 23. D & \\
\hline 24. go & 24 & \\
\hline 25. run & 25. s & \\
\hline
\end{tabular}




$$
\begin{aligned}
& \text { 26. D } \\
& \text { 27. D } \\
& \text { 28. S } \\
& \text { 29. D } \\
& \text { 30. S }
\end{aligned}
$$

XIII. Outcomes: These were observed by the writer during this unit.

(a) An interest in reading was stimulated in chlldren who had lacked a desire to read.

(b) Children who had already had interest stimulated were provided with much materlal to read.

(c) The teacher had an opportunity to note the progress which the children were making in reading by watching their behavior in the library. and was able to determine which books the children liked to read. She was able to determine which children read for pleasure and which ones read only Involuntarily.

(d) There was a greater skill in reading and Increased knowledge as a result of much reading.

(e) There was a development of creative ability in writing prose and poetry.

(f) Habits of courtesy and consideration for others in being quiet in the library were established.

(g) Chllaren learned how to use the books efficlently.

(h) Chlldren learned the proper treatment of books. 
(1) They learned how to obtain books from and return books to the Ilbrary.

(j) A desire to own more books was aroused.

XIV. Bibllography:

(a) Teacher's

Alden ........... Why the Chimes Rang Aldredge \& McKee ..... Read and Color

Balloy ............ A Story for Each Hollday

Bolen1as............ F1rst Grado Manual

Bolentus........... silent Reading in the Elementary Schools

Bryant ............ How to Tell storles to Children

Bryent, Sara C. .... Ploneer Girls and Boys Clouser, Robinson, Neoly,. Educative Experiences Through Activity Units

Coleman, UhI, Hosic ... Pathway to Reading Curry \& Clippinger .. Chlldren's Iiterature Curtis, Mary I., .... Why We Celobrate our Holidays

Fleld, Eugene, ...... Christmas Tales and Verse

Hardy, ........... Chlld's Own Way Series Manua I

Howard, Haw thorne, Howard,

A Primary Language Work Book

Jenkins, .......... Reading in the Primary Grades

Johnson, ........... First Grado Manual for Child-story

Kelly, Ruth, ....... Book of Hallowel en

Keyes, Angela, ,..... Storles and Story Telling

Kilpatrick, W.H., ... Foundations of Method

Laing, ............ Manual for Teachers One Hundred Best Poems ( 5 and 10 Cent store) Pooms for Iittlo Folks (5 and 10 Cent Stor $\theta$ )

stone, ............. Silent and Oral Reading 
Storm, Grace E., -...--The Soc1al Studies in the Primary Grades

Stevenson, R.L.,.......A ChIld's Garden of Verse

Tappan, Eva, ........ Letters from Colonial Children

Teacher's Gulde to Child Development,

California Stato Department of Education,

Miss Ruth Manning Hocket, Editor

W1ggins, Kate D., .... Tales of Laughter.

(b) Children's

Baker,C.B. \& Baker,E.D. . Pet Pony

Darby,F.M., ........... Jack and Susan Stories

Elson,W.H.,........... The Elson Readers

Primer

Elson,W.H.,........... The Elson Readers

First Reader

Falls, C.B., ............ The A B C Book

Fox, F.M., ...........Adventures of Sonny Bear

Fox, F.M., ............ Doings of Iittle Bear

Gates,A.I.,\& Huber, M.B., Around the Year

Gates,A.I.,\& Huber,M.B., Frlendly Stor1es

Gates,A.I.,\& Huber,M.B., Make and Make Belleve

Gates,A.I.,\& Huber,M.B., Peter and Peggy

Hahn, J.I., .......... Blily and Frlsky Play House

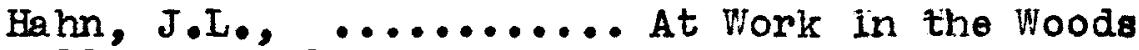
$\mathrm{H} 111$ \& Maxwe11,....... Charlie and His Kitten Topsy

H111 \& Maxwe11, ........ Charlie and H1s Puppy Bingo

Hunt, Clara, ......... About Harriett

LaRue, M.G., .......... In An 1 ... I land

LaRue, M.G., ......... The Fun Book

LaRue, M.G., .......... In Rabbitvilio

Orton, Helen, ............. Ned and Nan in Holland

Orton, Helen, .......... The Little Lost Pigs

Orton, Helen, ........... Prancing Pet

Putnam, $\mathrm{H} . \mathrm{W}, \ldots . . . \ldots . .$. Sunny Bunny

Potter, Beatr1ce,....... The Tale of Peter Rabbit

Tippett, $\quad$.......... I Go A-Traveling; I Live in a City

Zirbes, Laura, Workers. 


\section{UNIT II}

THE DRY GOODS STORE

I. APPROACH AND PROCEDURE:

A. Approach: During the month of March the chlldren began wearing new spring clothes. There were many comments on the new clothes regarding the material and patterns. On March 18, 1937, the teacher had a language lesson based on the changlng of seasons and what takes place.

Teacher: "What month is this?"

Child: "The month of March."

Teacher: "What does the month of March make you think of?"

Child: "Easter."

Child: "Kites and wind."

Child: "New spring dresses."

Teacher: "What season of the year 18 1t?"

Child: "Spring•"

Teacher: "What happens in the spring?"

Child: "Birds build new neston"

Child: "The trees begin to put on new green dresses."

Ch11d: "People get ready for spring, too."

Teacher: "Yes, everybody must prepare for spring. Everybody changes from heavy clothing to light clothing. Little boys and girls 
need someone to help them get ready, don't they? Mother usually helps them. Could you tell me how mother helps you to get ready for spring?"

Child: "She makes us new clothes."

Ch1ld: "She buys us new spring hats and coats."

Child: "Mother buys us new shoes."

Toecher: "Where does mother get these things?"

Ch1ld: "She buys them at the store."

Teacher: "What kind of store?"

Ch1ld: "Kaufman"s"

Child: "Stewarts."

Child: "My mother buys clothes at Bahis."

Child: "My mother makes most of my clothes."

Teacher:"What kind of store is Kaufmans and the other stores you mentioned?"

Ch1ld: "Department Stores."

Some time was spent discussing the various

departments in the store. Several children told of their experiences while at a department store. One child expressed his desire of wanting to go to a department store. Another sald that we had a Dry Goods Store on Bardstown Road. (Th1s store is just a block from the school bullding.) Another ch1ld suggested we visit the store on Bardstown Road, and then, if later we still wanted to go downtown we courd. The following day the class talked about going to the Dry Goods Store. They discussed the things 
they would look for while they were there. One child suggested that a list be made as to the things they really wanted to know about a Dry Goods store. These questions were asked by the chlldren, printed on a chart by the teacher, and hung up for the children to read.

What we want to know.

1. What does a Dry Goods Store have?

2. How does one measure materials?

3. How many inches are in a yard?

4. How many inches are in 1/2 yard?

5. What kind of material do you find in

a Dry Goods Store?

6. What are spring dresses made of?

7. What are shoes made of?

8. Are all shoes made alike? Why not?

9. Where does the material for our dresses, coats, and shoes come from?

10. Are all dresses made alike? Why not?

B. The Trip to the Dry Goods Store:

Since the tore was fust a block from school there was no transportation to be taken care of. The teacher and chlldren walked to the Crosby Dry Goods Store on Bardstown Road. In the store the children notlced the arrangement of the shelves, the different linds of material, and the many different articlea that are in a Dry Goods Store. The children asked the 
saleslady several questions that they had fotted down before coming to the store. They asked how the material was measured and what some of the prices were. When the chlldren had finished looking through the store the group walked back to school. After they returned the teacher gave the children on opportunity to express in picture the things they had seen.

C. Discussion after Trip and Planning of the Aotivities:

After the visit to the Dry Goods Store the children were quite enthusiastic about the operating of a store. They were anxious to know the source of the various materials. Flrot, the children wrote a short story about their trip. The story they composed read as follows:

\section{our Trip}

We went to the Dry Gooda Store.

We saw some material.

It was different colors.

Some was pink.

Some was o range.

Some was green.

Some had flowers and dots.

Some had checks and stripes.

Most of the material was cotton.

The following day this story appeared in

printed form on a chart which likewlse served as

Incidental reading material for the group.

The majority of material was cotton at the 
Crosby Dry Goods Store. One child asked where the cotton came from. The teacher let the chllaren tell what they knew about cotton. Some of them knew that cotton came from a plant but did not know how it became alece of material. There was a book in the library ontitled, Around about You, by Smith, which contained a story about cotton. The teacher referred the children to this book. Severel chlldren found the story, and one child asked if he could take the book home and practice reading the story so he could read it to the class the next day. The following day he read the story to the class. After some discussion about the source of cotton they wrote their own story. It read as follows:

\section{THE SOUTHERN SNOW}

Cotton grows from a seed.

It grows in the south.

You plant the seod in the ground.

The seedmust have rain and sunshine.

A bush comes up.

Then 1 t has a bud on 1 t.

Soon the bud pops open.

And out pops the white cotton.

A discussion of the source of other

materials such as silk and linen for our dresses, wool for our coats, and leather for our shoes took place. The chlidren brought in samples of varlous kinds of material. These were mounted on a chart and labeled. The children were "materlal consclous " They noticed 
each other's clothes and named the different kinds of material in each.

After several lessons in telling how the store was operated and/whet it consisted, one child suggested that the class try to bulld a store and operate 1t. The teacher told the children to think about this suggestion. The children thought about it and brought thelr suggestions the followIng day.

\section{Constructing the Dry Goods Store: The chlldren discussed the things they} wished to include in their store. They dictated the Iist to the teacher who wrote 1t on the blackboard and then printed it on a chart. The list included:

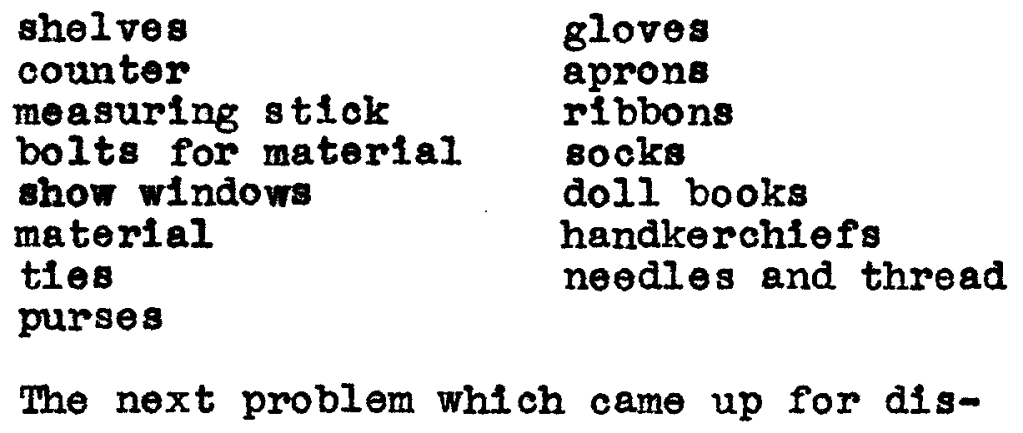

In the next group discussion the children 
committees were:

Committee for bullaing the shelves for the store. Commit tee for making material. Committer for making gloves. Committee for making handkerchiefs. Committee for making purser. Commit tee for making socks. Committee for making ties.

There were five children on each committeo. Each committee chose a chaiman. The chairman on the Store Committee asked if the other children would try to bring some orange crates. He told them that his committer would neod about ten orange crates. Fach member of the class cooperated with him and did his part.

The following morning the children came to school with orange crates they had gotten from the Plggly Wiggly at the corner. The Store committee immediately arranged the crates so that they would form a counter and shelves. They painted these crates with green calimo. While this comittee was working on the store the other committeos were making material, gloves, socks, aprons, ties, handkerchiefs, and purses. These articles were made from paper. Flgure V reveals the various articles the children made for the store. After the store was completed the children had interesting experiences buying and selling the things In their store. Each child made play money from card- 


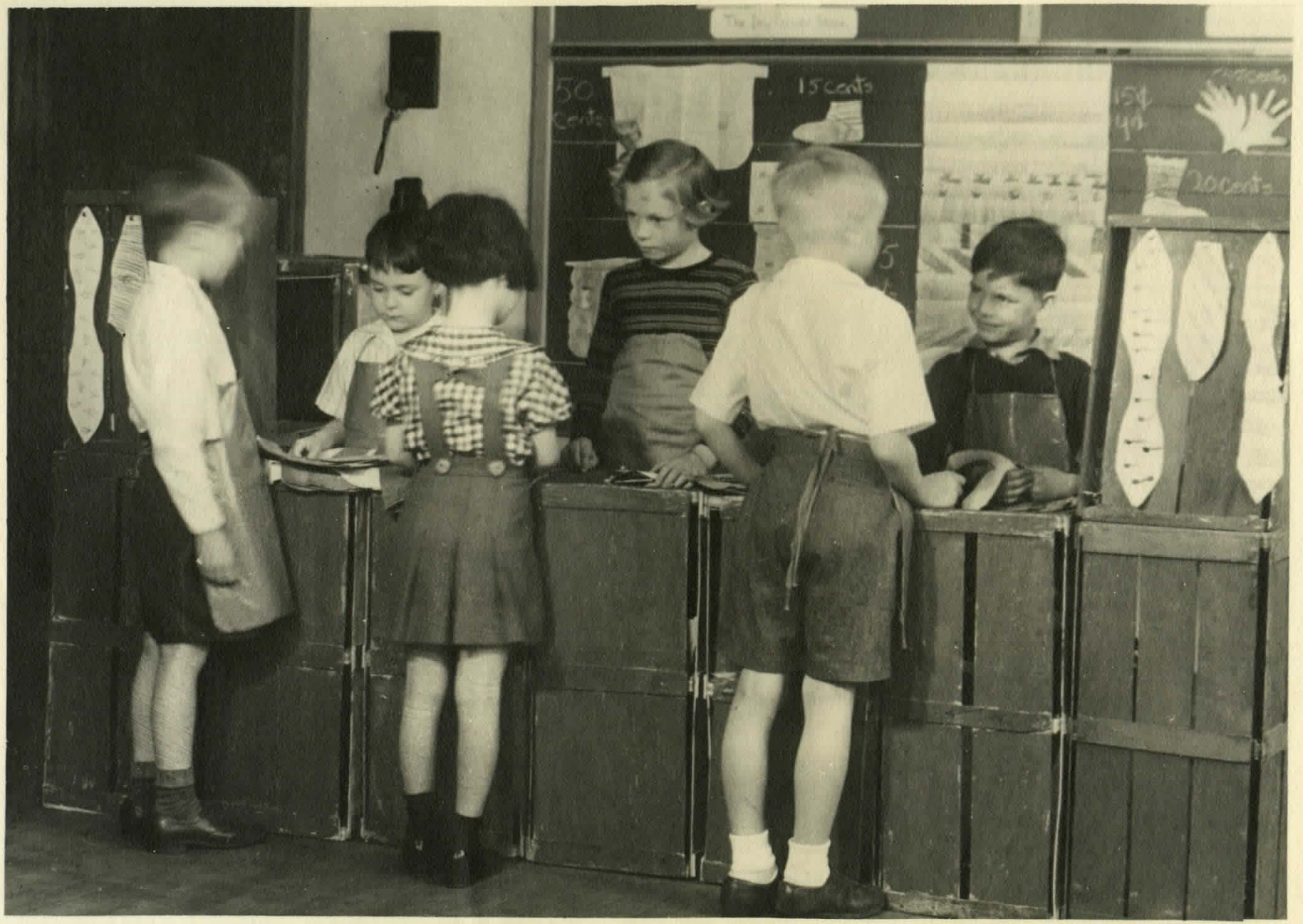

Photo By GEORGE A. RUEDEMAN

Figure V shows Dry Goods Store completed. 
board. Thelr money consisted of half-dollars, quarters, dimes, nickels, and pennies. One dey one of the children asked if they could have real things In their store. Another child remembered that they had been saving their pennies, so he suggested they buy some real material at the Dry Goods Store on Bardstown Road. The children counted their pennies. They had saved $\$ 2.05$. They tork their money and walked to the Dry Goods Store and bought some material. After looking at the material they decided to buy seven yards of cotton at fifteen cents a yard. They bought two yards of green, two yards of blue, and three yards of pink. Then they bought two yards of green oilcloth and two yards of blue oflcloth at twenty-five cents a yard. The saleslady had two empty bolts; so she gave them to the children. When the children returned to the school they put the material on the bolts just as it was done at the real store. They rolled the ollcloth so it would not crack. They priced their material the same as the real store. They had no way of measuring the1r material; so they made a yard stick out of cardboard and tacked it to the counter. The next day each child played clerk and sold some material, and each child was a customer and bought some material. Each child bought one half yard of material. The boys bought olleloth and the girls bought the cotton material. 
The children used their play money. They had to to make correct change. The teacher stood near and acted as a guide when the children came to a combination they did not know in making change. A notation was made regarding these combinations and at another perlod the teacher taught the combinations that were miseed while playing store. Th1s unit provided a wealth of arithmetic material for these children. Each child made an apron from his material. In Figure VI one can seo a group of children very busily sewing on their aprons. There was some o1lcloth left; so the chlldren made coln purses. When they had finished they decided to give them to their mothers for Easter. At the close of this unit a test of one hundred questions was given. This test is given in full later in this discussion.

II. OBJECTIVES:

A. General objectives:

1. To stimulate a greater interest in the community in which the child lives.

2. To develop in the child an appreciation for the work that is necessary before he can have the clothes he wears.

3. To provide opportunities for self-expression in art and writing.

4. To develop attitudes of helpfulness, cooperation, carefulness, and appreciation of the work of the members of the group. 


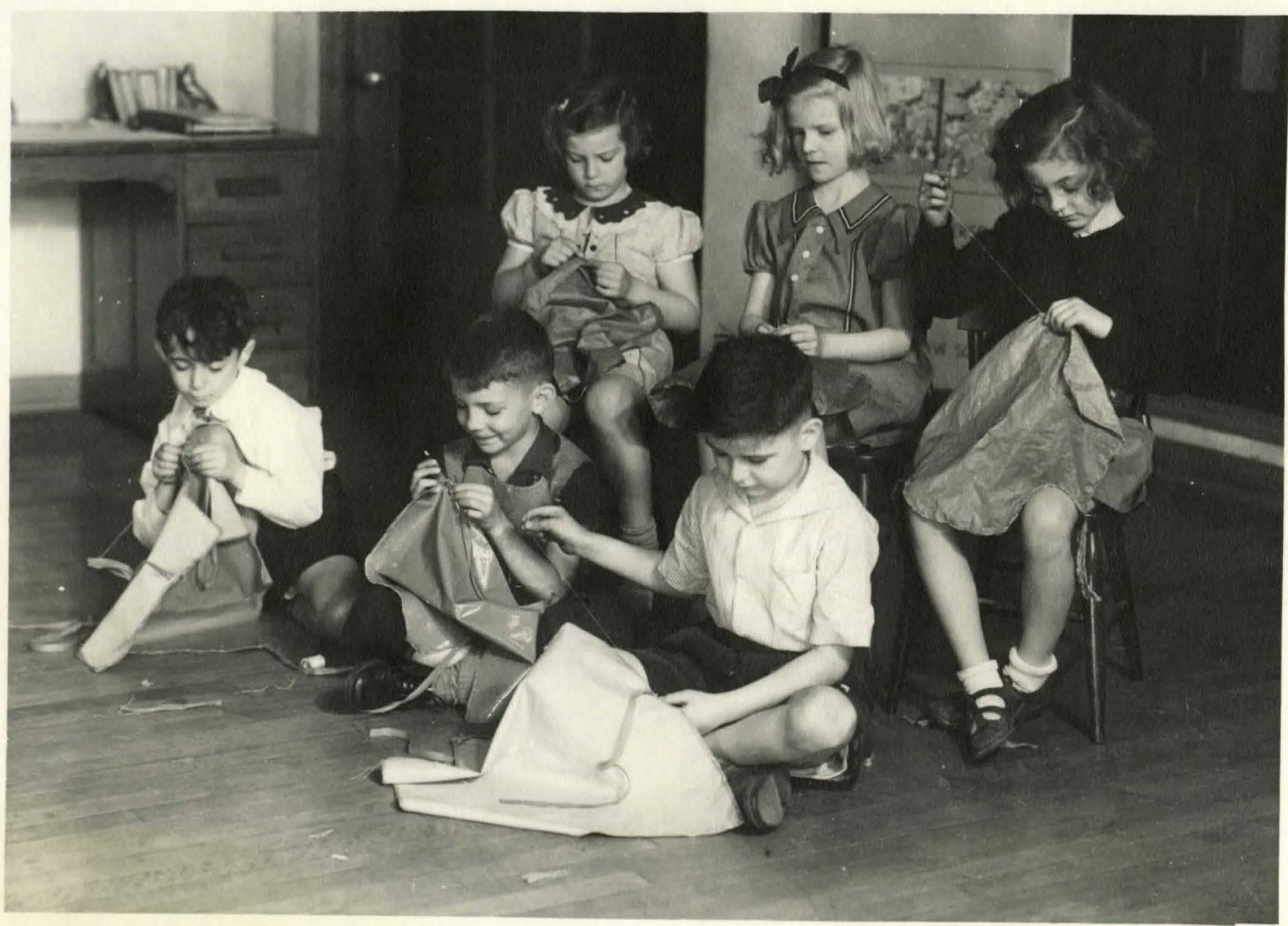

Photo By george A. RUEDeman

Figure VI. A group of children from 1A-2B Class, at Longfellow School, Loulsville, Ky•,

sewing on their aprons. 
5. To provide opportunities for number work through real ilfe situations.

B. Children's objectives:

1. To visit a Dry Goods Store.

2. To build a store in the room.

3. To make things for the store.

4. To play store:

(a) buying.

(b) selling.

5. To make an Easter present for Mother. III. SUBJECT MATTER:

The experiences embraced in the study of the Dry Goods Store brought in a need for reading, arithmetic, spelling, language, writing, safoty, art, Industrial art, and health.

\section{A. Reading:}

1. Reading of the bulletin board.

(a) Notices for the ensuing day.

(b) Best work or 1mproved work.

(c) Pictures with a statement about the pictures.

2. The children formulated stories of their trip to the Dry Goods Store and about some of the articles made for the store. All storles composed by the children were printed on a large chart and hung in the room for each chlld to see and read. 
3. Reading the storles in books about cotton, wool, and leather.

B. Arithmet1c:

1. Counting.

(a) The number of different articles in the store.

(b) The number of like articles in the store.

(c) The money in the cash register that was taken in when playing store.

(d) Each child counting his own money.

(e) The money in the children's penny bank.

2. Addition.

(a) Finding the amount of the bill when children bought more than one articlo.

Examples:

\begin{tabular}{|c|c|c|}
\hline $\begin{array}{l}\text { Tio } \\
\text { Apron } \\
\text { Totel }\end{array}$ & $\begin{array}{l}25 \not \\
156 \\
\end{array}$ & $\begin{array}{l}\text { So cks } \\
\text { Handker- } \\
\text { chlefs } \\
\text { Purse }\end{array}$ \\
\hline & & Total \\
\hline
\end{tabular}

3. Subtraction.

(a) Finding out the amount of money the chlid had left after golng shopping.

Example: 25\& Amount the child had when going to the store 15 d spent

$10 \not$ left

(b) Taking inventory of stock each day.

Example: 20 ties on shelf

10 ties sold

10 ties left 
4. Measuring.

(a) Measuring the material that was bought and sold in the play store, using the measurements of one yard and one half yard.

(b) Use of yard stick.

5. Value of money.

(a) Cost of material and articles in the Dry Goods Store: 15\%; 25 ; 10ф; and $40 \%$.

(b) Value and use of penny bank.

1. How to spend the money.

6. Thought problems.

(a) If one yard of material cost $20 \%$, what will $1 / 2$ yard of material cost?

(b) If you buy one tie for 25k, what w1II you pay for 2 ties?

(c) One yard of material costs $15 \%$. How much w11l you pay for 3 yards?

(d) How much money will you spend if you buy one apron for 15\&; two handkerchlefs for $10 \not$, and a purse for $20 \%$ ?

(e) Jane bought an apron for 25\%; Sally bought a purse for $20 \&$. How much did the two giris spend together?

C. Spelilng:

1. Subject matter.

store
apron (8)
paint
handkerchlefs
purse
socks
cents
ribbon
shelves
pocket-book

hats

shoes

coats

cotton

gloves

material

yard

buy

window

Dry Goods Store money green

sell flowers

made dots

dress stripes

spring pretty

werm come

money fun

shelf measure

bolts oll-cloth 
2. Speli1ng seatwork.

(a) Can you pick out the little words in these big words?

$\begin{array}{lll}\text { store } & \text { socks } & \text { gloves } \\ \text { hats } & \text { opring } & \text { shoes } \\ \text { buy } & \text { warm } & \text { shelf }\end{array}$

(b) F111 in the blanks with spelling words.

1. We went to the

2. They sell yards and yards of

3. You need when you go to the Dry Goods Store.

4. The material is wrapped on

5. The 011-cloth is not crack. so 1 t $* 111$

\section{Writing:}

This unit calls for several writing lessons about auch topics as:

1. What we saw at the Dry Goods Store.

2. Writing price tags for the articles in the store.

3. Writing a list of things in the store, and making an inventory of the stors.

4. Writing orc applying speli1ng words in coptions and stories.

E. Language:

1. Oral language.

(a) Class discussion before the visit to the Dry Cooda Store. Children made a list of questions they wished to find the answers to.

(b) Cless diacussions after visit to the Dry Goods Store.

(c) Making plans for the bullding of the store. 
(d) Composing storles about the trip, their gloves, and pocket-books.

2. Written Language.

(a) The following is a list of questions made by the class. These questions rere answered through the help of the teacher and stories found in books.

1. What does a Dry Goods Store have?

2. How do you measure the material?

3. How many inches in a yard?

4. How many inches in one half yard?

5. What kind of material does the Dry Goods Store have?

6. What are spring dresses made of?

7. What are coats made of?

8. What are shoes made of?

9. Where does cotton, wool, and leather come from?

10. Are all dresses made alike? Why not?

(b) Storles composed by the children written by them and put into booklets.

\section{OUR TRIP}

We went to the Dry Goods Store.

We saw some material.

It was different colors.

Some was pink.

Some was orange.

Some was green.

Some had flowers and dots.

Some had checks and stripes.

Most of the material was cotton. 


\section{THE SOUTHERN SNOW}

Cotton grows from a seod. It grows in the south. You plant the seed in the ground. The seed must have rain and sunshine. A bush comes up. Soon the bud pops open. And out pops the white cotton.

\section{OUR GLOVES}

We made gloves this morning. We made them for our store. We had to trace our hands on the paper. Wo had to make four gloves. We pasted the two right gloves together. We pasted the two left gloves together. Then we colored the gloves. We had fun making the gloves. The children who finished first made pocket-books.

\section{OUR POCKET-BOOKS}

Yesterday we made pocket-books.

We made them for mother for Easter. We made them out of oflcloth. We had to sew them, too. Tom sa1d, "I had more fun making my pocket-book."

We hope mother will be happy.

F. Eөelth:

1. Posturo.

(a) Desirability of correct posture while sitting and standing.

2. Dress carefuliy for the weather when going on shopping trips.

3. Cleanliness in the children's store.

G. Safety:

1. In constructing the Dry Goods Store it was

urged that carefulness is always best when handling 
Baws, hamers, nalls, and boards.

2. Nalls are not left lying around on the floor. Na1ls are not left sticking in boards. They are pulled out and put away. The boards are put away where they will not be stumbled over.

3. Safoty on street when going on trip.

\section{H. Art:}

Applied in as practical a manner as possible.

1. Draw pictures of what children saw on their trip.

2. Make all-over designs for materlals. Some

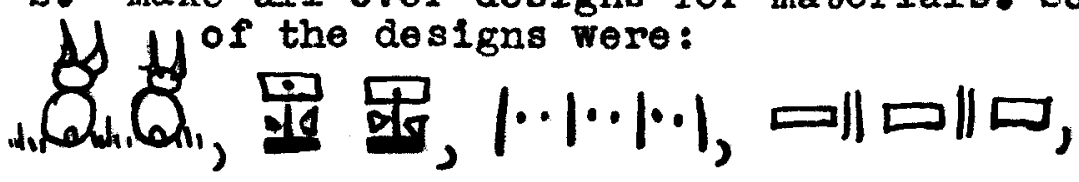
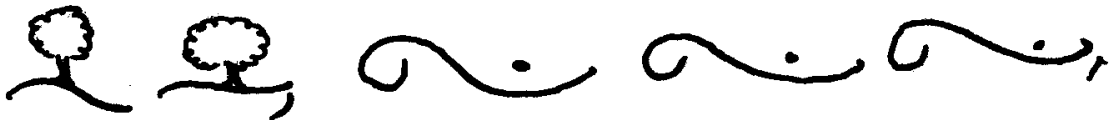

3. -

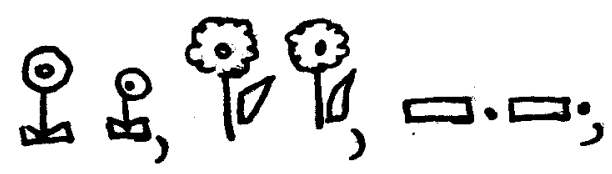

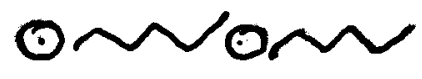

I. Industrial Art:
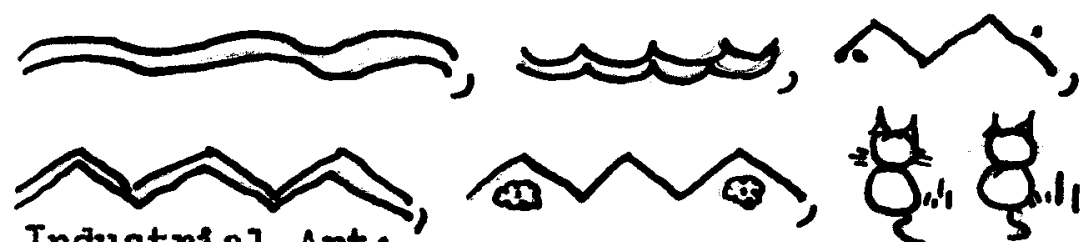

1. Constructing a Dry Goods Store in the room. (a) Shelves. 
(b) Show windows for store.

(c) Gloves for store.

(d) Pocket-books.

(e) Ties.

(f) Handkerchiefs.

(8) Socks.

(h) Aprons.

(1) Material.

2. Book conteining stories, pictures, and charts about the unit.

3. Doll books containing a doll and a complete wardrobe for 1 t.

J. Musie:

The song material was taken from the second grade outline in the Course of Study in Music for the Loulsville Public Schools.

K. Test:

An objective test of 100 questions was given to the group at the end of six weeks. The reliability of this test by the Spearman-Brown Formule is .91 \pm .021 . Following is a copy of the test given.

Completion: Directions: Fill the blanks with the correct word. Example: Two yards and three yards are flve yards.

1. You can buy material at the

2. To buy anything at the Dry Goods Store you must have

3. You measure material with

4. There are inches in one Jard. 
5. A Dry Goods Store has many

6. If one yard of material cost 15 cents, two yards will cost cents.

7. There are inches in a half of yard.

8. If you buy an apron for 20 cents you will get cents from 25 cents.

9. Some spring dresses are made from

10. Some apring dresses are made from

11. Shoes are made from

12. Coats are made from

13. Wool comes from the

14. Cotton comes from a

15. You can buy things at the Dry Goods Store.

YES OR NO:

Directions: Write yes or no by each sentence. If the sentence is correct, write yes. If it 18 not correct, write no.

Example: Birds can hop. No.

1. You can buy books at the Dry Goods store.

2. If you pay 15 cents for a yard of material you will get 20 cents back from 25 cents.

3. You can buy handkerchlefs at the Dry Goods Store.

4. Shoes are made of cotton.

5. You can buy aprons, ribbons, and socks at the Dry Goods Store.

6. Cotton comes from a seed.

7. If you pay 8 cents for one half yard of material you will get 2 cents from a dime.

8. You need money when you go to the Dry Goods Store. 
9. There are 36 inches in one half yard.

10. Wool grows on a tree.

11. The Dry Goods Store sells bread.

12. The Dry Goods Store has many show cases.

13. The Dry Goods Store has a yard stick to measure material.

14. You can buy gloves and pocket-books at the Dry Goods Store.

15. Two yards and five yards are elght yards.

16. Four aprons and six aprons are ten aprons.

17. Two gloves make one pair of gloves.

18. You usually buy one sock at a time.

19. You buy material by the foot.

20. Shoeg are made from wool and leather.

21. S1x handkerchlefs and five handkerchiefs are eleven handkerchlefs.

22. Five aprons and four aprons are nine aprons.

23. If one yard of material cost 15 cents, two yards will cost 25 cents.

24. Three aprons and two socks are five aprons. 25. At the Dry Goods Store you can buy ollcloth. 26. All material is the same colox.

27. You can buy ties of all colors.

28. All material is made of cotton.

29. Some material is made of wool.

30. You can get I1brary books at the Dry Goods Store. 


\section{Multiple Cholce:}

Directions: Draw a ring around the

right answer.

Example: Dogs can (hop, (bark, sing, dance.)

1. At the Dry Goods Store you can buy (bread, doga, material, glasses, pencils.)

2. Six yards and seven yards are $(13,15,9,6,12)$.

3. The Dry Goods Store is a (11brary, store, school; house, book).

4. Dresses are made of (leather,glass, cotton, flowers, wood).

5. Four aprons and elght aprons are $(9,13,16,13,15)$

6. There are $(23,18,25,30,36)$ inches in one yard.

7. If you have 15 cents and spend 8 cents for some material you will have $(6,7,10,5,8)$ cents left.

8. If you have 18 cents and spend 15 cents for an apron you will have $(7,1,3,10,6)$ conts left.

9. There are $(30,18,16,36,25)$ inches in one half yard.

10. Shoes are made of (cotton, s1lk, leather; glass, wool).

11. Coats are usually made of (s1lk, wool, wood; glass, flowers).

12. If you have 10 cents and send 5 cents for some ribbon you will have $(6,16,9,7,5)$ cents left.

13. At the Dry Goods Store you can buy (aprons, books, bread, apples, lettuce).

14. At the Dry Goods Store you can buy (carrots, rabbits, socks, milk, cakes):

15. Nine yards and seven yards are $(16,18,15$, $7,17)$ yards. 
16. At the Dry Goods Store you can buy (gloves, apples, candy, nalls, cars).

17. Tho Dry Goods Store has many (books, chairs, shelves, tables, clocks).

18. Three aprons and four aprons are $(6,9,7$, $8,5)$.

19. Flve palr of gloves and four pair of gloves are $(6,10,9,7,8)$ pair of gloves.

20. S1X cents and five conts are $(12,13,9,11,10)$.

21. Wool comes from the (sheep,dog,cat, rabb1t, cow).

22. Cotton comes from a (buIb, seed, cow, sheep, acom).

23. If you have 15 cents and spend 10 cents you w11l have $(6,5,7,8,9)$ cont left.

24. If you have 16 cents and you spend 8 cents you w1Il have $(9,6,4,7,8)$ cents left.

25. Seven ties and five ties are $(10,11,9,12,14)$.

26. You buy ties at the (Grocery, Bakers, Dry Goods Store, Post Office, Library).

27. You buy shoos at the (Grocery, Shoo Store; Bakery, Library, School).

28. You buy aprons at the (Bakery, Grocery, Drug Store,Dry Goods Store, Post Office).

29. Six yards of ribbon and three yards of ribbon are $(5,7,9,11,2)$ yards of ribbon.

30. Nine ties and two ties are $(11,13,15,9,17)$ ties.

Matching:

Match the things in the first column with the things in the second colurm. 


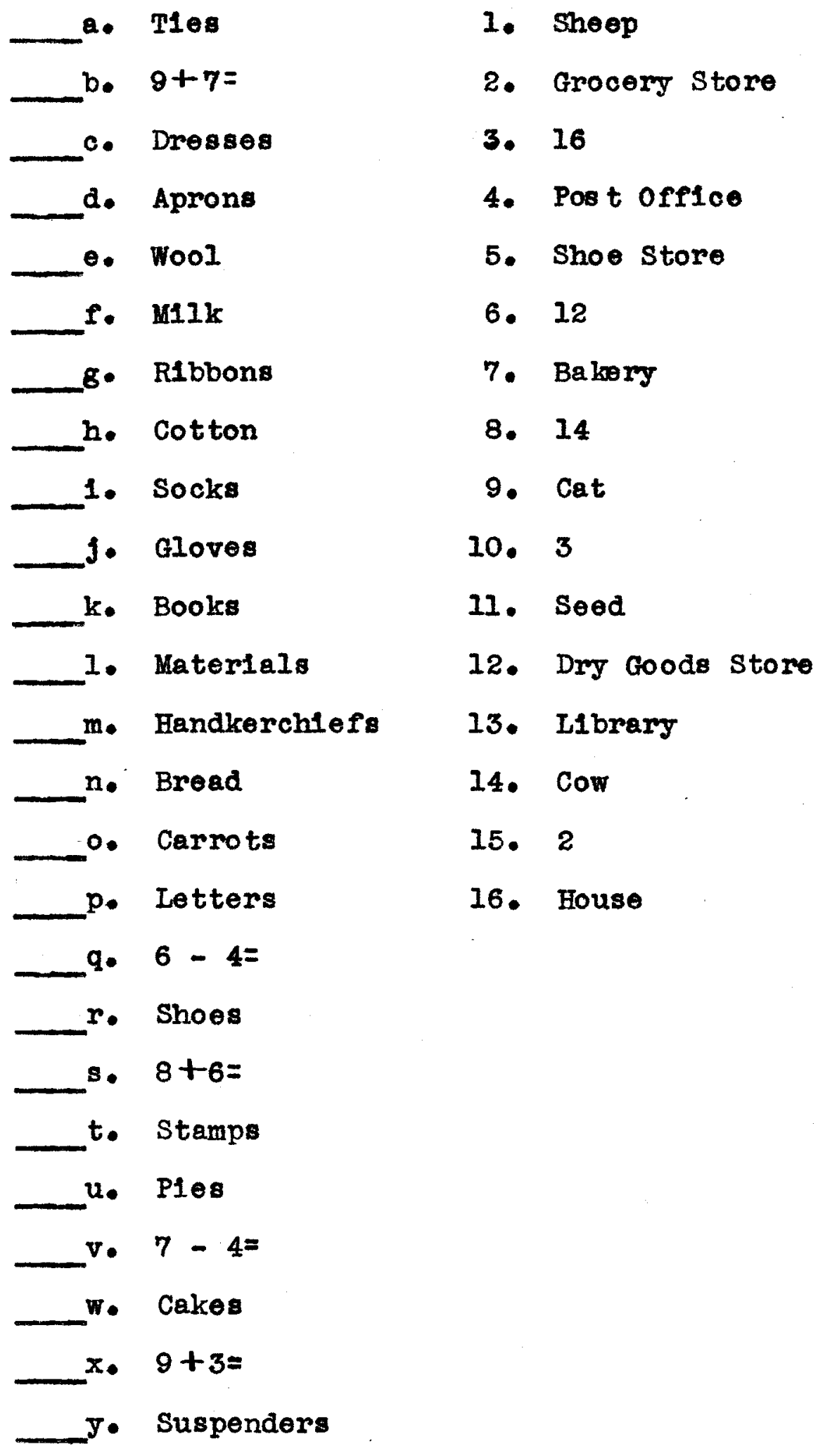




\author{
Completion \\ 1. Dry Godds Store \\ 2. Money \\ 3. Yard stick \\ 4. 36 \\ 5. Shelves \\ 6. 30 \\ 7. 18 \\ 8. 5 \\ 9. Cotton \\ 10. Linen \\ 11. Leather \\ 12. Wool \\ 13. Sheop \\ 14. Seed \\ 15. Mang
}

Multiple Choice

1. Material

16. gloves

2. 13

3. store

17. shelves

4. cotton

5. 12

6. 36

7. 7

8. 3

9. 18

18. 7

19. 9

20. 11

21. sheop

22. sood

23. 5

24. 8

10. leather

11. wool

25. 12

12. 5

26. Dry Goods Store

13. aprons

27. Dry Goods

Store

14. socks

15. 16
Yes or No

1. No 16. Yes

2. No 17. Yes

3. Yes 18. No

4. No 19. No

5. Yes 20. No

6. Yes 21. Yes

7. Yes 22. Yes

8. Yes 23. No

9. No 24. No

10. No 25. Yos

11. No 26. No

12. Yes 27. Yes

13. Yes 28, No

14. Yes 29. Yes

15. No 30. No 
IV. OUTCONE OF THE UNIT:

The following list represents specific information and ideas which the children learned from the Dry Goods Store unit as observed by the writer:

1. What can be bought at the Dry Goods Store.

2. Where some of the materials come from.

3. That the courteous attitude of the Dry Goods Store keeper and his helpers toward the public contribute to his success.

4. That customers must be courteous if they expect courtesy.

5. The necessity of attractively arranged goods.

6. An 1dea of measure, as: yard, dozen, pair, Inch (Inches).

7. Civic values:

Clerk greet customer. Customers greet. clerk. Clerk says, "Thank you, call again.", courtesy.

Neatness.

Promptness.

Honesty.

An Important outcome of the Dry foods store

unit lies in the furthering of interests and skills in other subjects. They are:

1. Interest in number work aroused by marking goods, and buying, and selling.

2. Improved oral composition because of keen interest in teling what they saw and what they knew about the Dry Goods Store and their construction of it. 
3. Interest in reading stimulated by charts which they composed about the store, also by plctures on bulletin board with sentences underneath them, and the reading of labels in the store.

4. An interest in entire community awakened because of collecting material for the atore.

\section{Blbliography:}

Carey, A.E., Hanna, P.R., and Meriam, J.L., Catalog of Units of Nork, Activities, Projects, Etc., to 1932. Teachors College, Columbia University, N.Y., 1932.

Classroom Teacher Volume II, The Classroom Ieacher, Ince, Chicago, III., 1927.

Clouser, Robinson, and Neely; Educative Experience Through Activity Units, Lyons \& Carnahan, Chicago, III.

Smith, N.B., Around about You, Silver \& Burdett Co., Chicago, III.

Smith, N.B.; At Home and Away, Silver \& Burdett Co.s Chicago, III.

Storm, G.E. The Social Studies in the Primery Grades, Lyons \& Carnahan, Chicago, III!: 1931.

Studebaker, J.W., and Others, Number Stories Book Two, Scott, Foresman \& Company, ChIcrgo, III., 1933. 


\section{UNIT III}

THE POST OFFICE

I. Approach and Procedure:

\section{A. Approach:}

The librarian of the Highland Branch Library visited the children's library in their room. She had remarked that when the children finlshed their library she would like to visit them. When it was completed the children wrote a letter inviting the librarian to visit them. When she came they told her about their library and read some storles to her. One child read some riddles from a book ontitled, What Am I. The librarlan said that she did not have that book in the library and would like to have one on the shelves of the library of which she is librarian. The teacher took this opportunity to Introduce the Post office Unit. Teacher: "What did the Ilbrarlan say she would like to have?"

lst Chlld: "A riddle book:"

2nd Child: "What Am I , was the name of it."

3rd Child: "I wish we could send her one:"

Teacher: "How could we send it?" 


\section{lst Child: "We could take it to her." and Ghild: "Oh, lot's mall 1t."}

From this conversation a discussion arose as to wat must be done in order to mall a package. Facts gained from this discussion were as follows:

1. Tell who the package is from.

2. Wrap the package securely.

3. Address the package correctly.

(a) Sender's name and address.

(b) Receiver's name and address.

Teacher: How many people would like to seo how the packages go through the mail?

1st Chlld: "I'd like to see 1t. How cen we?" 2nd Chlld: "Could we go to the Post Office?" Teacher: "I think it can be arranged." The following day there was a discussion about going to the Post office. The teacher made arrangements with the postmaster to visit the main Post office. First, it was necessary to write a note to mother asking permission to go. The transportation was taken care of by mothers consenting to drive the children in their cars. The remaining part of the discussion dealt with various points of interest they wished to know. The following 
points were brought up for discussion:

1. What shall we look for at the

Post office?

2. How shall we act on the way?

3. How shall we act while we are there?

Responses from the group to the last two

questions were:

People expect us to be orderly.

Wait at crossings if it is necossary to

cross the street.

Be courteous to the mother driving the car.

Listen carefuliy to what the postmaster

tells us.

Some interesting questions asked by the children about the Post offlce were listed and printed on a chart by the teacher, and hung up for the children to read. Following are the questions:

1. How many ways does mall travel?

2. What happens when you forget the stamp?

3. What happens if you have the wrong address?

4. What happens if the letter is not addressed?

5. Why is mail important?

6. How is the mall delivered in the country?

7. How does the mail get to the Post office? 
8. Why do we wrap packages?

9. Where can you buy stamps?

10. How many different kinds of stamps are there?

11. Where is the main Post office located?

12. Why do we have Special Delivery?

13. Why do they sort the mail?

14. What is the "Dead Letter Office"?

15. How does the postman know where to take the letters?

16. How can we help the postman?

\section{B. At The Post office:}

The postmaster took the chlldren through the work room. He explained carefulity to the children just how the mail is handled from the time It comes into the Post office until it is delivered. Keen interest was taken in the sorting of the mail and In the cancelling machine. The children had with them the book they wanted to send to the librarian. They wrapped and addressed it carefully before leaving school. The postman showed the children how the1r package would go through the Post Office. Several children brought personal letters to mall. They purchased the stamps for them and put them in the outgoing mail basket. C. Discussion Following The Trip: 
Office one child suggested that they build a small post Office in their room. All the children were anxious to do this. The teacher knew that there would have to be some organization and discussion of the things they had seen and some defintte planning of the undertaking before they could start any construction. Therefore, aince the next period was a composition period she felt that a discussion of their trip would constitute a most vital toplo for an oral language lesson. The chlldren were allowed to tell what they had seen while at the Post office. From the information given by the chlidren a story was composed. This story appeared in printed form on a chart which likewlse served as reading material for the group. Following is the story:

\section{IN THE BIG POST OFFICE}

We saw many, many things.

We saw a stamp machine.

We saw many pigeon holes where they sort the mall.

We saw something that looked like a sliding board.

It was a chute for packages to silde down.

We heard something say, "Peep, peep".

We looked around and saw boxes of baby chloks.

We saw many, many mail bags.

We saw the Special Delivery cage.

We saw a man in another cage.

He was selling stamps.

Stanley bought some stamps.

We saw letters come through the letter slot. We saw the counting machine.

The visit to the Post Office was interesting. 


\section{Constructing The Post office:}

The next step was the construction of the Post office. The children selected committees on which they wished to serve. The committees were as follows:

Bullding Committeo.

Ma11box Committee.

Pos tman Committee.

Furnishing Comittee.

They were asked to name the things needed

by each committer. The following 1tems were

suggested for the following cormittees:

Building Committeo:

$$
\begin{aligned}
& \text { walls } \\
& \text { plgeon holes } \\
& \text { windows (for stamps } \\
& \text { (for parcel post } \\
& \text { letter slots (for regular mail } \\
& \text { (for special delivery }
\end{aligned}
$$

Postman Comm1tteo:

caps

mail bags

Ma1lbox Cormilttee:

mallbox to be used in hall

Furnishing Cormitteo:

desks and stools

stamps

stamper

penc11

pen and Ink postal oards

package chute 
The children went down into the besement of the school bullding and found some orange crates with which to bulld the Post Offlce. They arranged the crates in order to represent a Post Office. They decided to paint it brown. The boys who were going to paint brought the work aprons that they made when studying about the Dry Goods Store. They mixed the brown caltmo under the directions of the teacher. After the painting was finished they took several large sheets of brown paper 24 inches by 26 inches, cutting a window for the clerk to see through, and cutting two letter slots, one for "Letters ;" and one for "Special" and "Air Mail" letters. On the other end they drew a panel to look like the General Delivery boxes. Pigeon holes were made from brown strawboard and pasted on one end of the blackboard. On the other end of the blackboard properly addressed imftation packages were pasted to represent the package chute. When the Post Office was completed the children got the mall from the Principal's Office that the real postman brought for the teachers in the building. Each teacher had a pigeon hole in the children's Post Office. The mall was sorted and 
then delivered by chlldren postmen. The Postman Comitteo made postman hats and bags. Letters were written to chlldren who were absent. This unit provided an abundance of written and oral language, reading, spelling, and arithmetic. At the close of this unit a test of one hundred questions was given. This test is given in full later in the discussion.

\section{Objectives:}

A. Teacher's Objectives:

1. To acquaint the children with one of the country's greatest institutions, the Post Office.

2. To familiarize the chlldren with the processes involved in sending a letter, tracing it from its starting point to 1 ts destination.

3. To develop an appreciation of the services rendered to soclety by the postman and the workers in the Post office.

4. To teach the children to cooperate with those who carry public responsibility, thereby ostabilshing desirable attitudes.

5. To develop skill in tool subjects through normal activity.

6. To have the chlld feel reoponsiblo for a doesnte part in $R$ group activity.

7. To teach the hast: of being observant.

8. To develop skili in planning work. 
9. To give the child the desire and ability to express himself by providing something interesting and worthwile to discuss.

10. To develop leadersh1p, initiative; and originality within the child.

B. Child's Objectives:

1. To visit the Post office.

2. To bulld a Post offl ce in the room.

3. To play Post office.

4. To write and recelve letters.

III. Subject Matter:

The unit of the Post Office offered stimulating subject matter for reading, orithmetic, spelling, language, writing, safety, art, Industrial art, and health.

A. Reading:

1. Reading of the bulletin board.

(a) Notices for the ensuing day.

(b) Best work or Improved work.

(c) Pictures with a statement about the pictures.

(d) Letters recelved from absent clas smates.

2. The children formulated stories of their trip to the Post offl ce. All of the stories composed by the children were printed on a large chart and hung in the room for each child to see and read. Flgure VII shows one of the many storles composed by the children. 


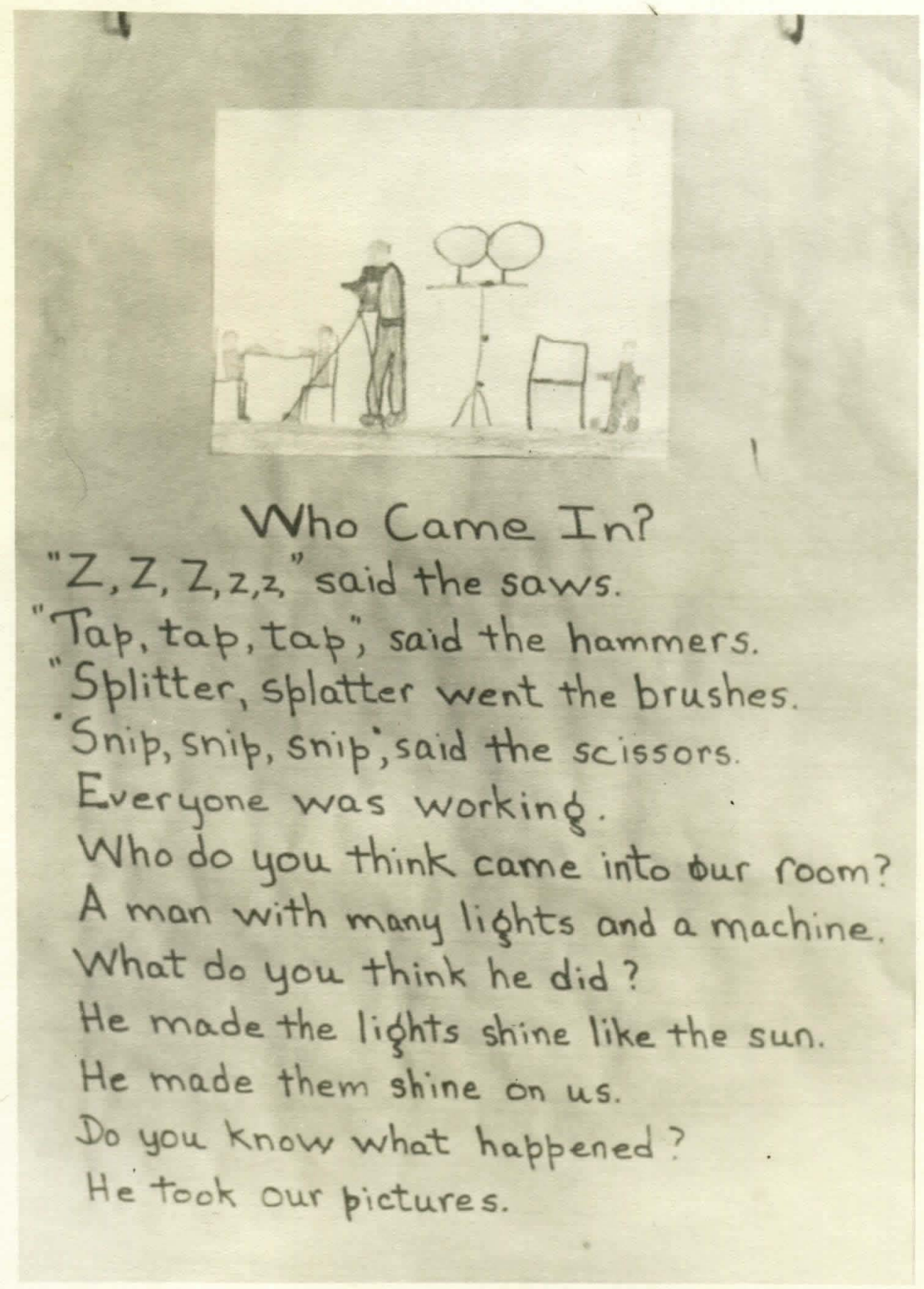

Photo By GEORGE A. RUEDEMaN $\begin{array}{ll}\text { Figure VII. Story composed by the children in the } & \text { St } \\ \text { IA-2B Class at Longfellow School, Loulsville, Ky. }\end{array}$ 
3. Roading stories in books relating to the Post offlce. (See list in children's bibliography.!

\section{B. Arthmetic:}

1. Counting.

(a) Counting letters, envelopes, stamps, and packages.

(b) Counting and listing the amount. left in cash drawer each day.

(c) Each child counting his own money.

(d) Counting the money in the children's penny bank.

2. Time.

(a) Meaning of the symbols A.M. and P.M•

(b) Telling time by hour and half hour.

3. Addition and Subtraction.

(a) Making change.

(b) Buying and selling stamps (using the simple combinations).

(o) Adding cost of packages.

4. Value of money.

(a) Make toy money to be used in the Post office.

(b) Cost of stamps, envelopes, and packages.

(c) Value and use of penny bank.

1. How to spend the money.

5. Thought problems involving the use of simple combinations.

(a) If you buy one $3 \not$ stamp and one 
2\& stamp, what wi11 the two stamps cost?

(b) Sally bought two $3 \notin$ stamps. How much change will she get from a dime?

(c) Dick bought two $3 \notin$ stamps, three $5 \&$ stamps and five 1 \& stamps. How many stamps did he buy for his stamp book?

(d) One Speciel Delivery stamp and two $3 \&$ stamps w11l cost how much?

C. Speling:

1. Subject matter. Ilst of words used for speling.

$\begin{array}{ll}\text { letter(s) } & \text { postman } \\ \text { send } & \text { ma11 } \\ \text { buy } & \text { seli } \\ \text { truck } & \text { sacks } \\ \text { Dear } & \text { name } \\ \text { friend } & \text { bag } \\ \text { you } & \text { card } \\ \text { stamp } & \text { busy } \\ \text { box } & \text { time } \\ \text { red } & \text { visit } \\ \text { cap } & \text { place } \\ \text { went } & \text { cost } \\ \text { away } & \text { work } \\ \text { post } & \text { class } \\ \text { save } & \text { money } \\ \text { school } & \text { Post off ice }\end{array}$

$\quad$ air
a irplane
train
package(s)
address
atreet
date
sort
parcel
cancel
city
station
carry
write
airport
envelop(s)

2. Seatwork.

(a) Fill in the blanks with spelling words.

1. The postman delivers $\ldots \ldots$

2. The postman carries a brown

3. At the Post office we can buy

$$
\text { - - - - - }
$$

(b) Can you pick out the little words in these big words?

$\begin{array}{llll}\text { send } & \text { trair } & \text { letter date } \\ \text { dear } & \text { gtamp } & \text { time } & \text { away }\end{array}$


D. Writing:

Th1s unit required much writing. At the time this unit was in progress there were a number of the children out with whooping cough. The children at school wrote their classmates letters. They wrote some of the stories they composed and sent them to their classmates.

1. Writing letters.

2. Writing and applying spelling words in captions and stories.

\section{E. Language:}

1. Oral language.

(a) Clags discussion before taking the trip to the Post office. Children made a list of questions they wished to find the answers to.

(b) Class discussion after the visit to the Post office.

(c) Making plans for the building of the post office.

(d) Composing stories about the trip and interesting sights they saw on their trip.

2. Written language.

(a) Following is a list of questions made by the class. These questions were answered through the help of the teacher and stories found in books.

1. How many ways does mall travel? 
2. What happens when you forget the stamp?

3. What happens if you have the wrong address?

4. What happens if the letter is not addressed?

5. Why is mail important?

6. How is the mail delivered in the country?

7. How does the ma1l get to the Post office?

8. Why do we wrap packages?

9. Where can we buy stamps?

10. How many different kinds of stamps are there?

11. Where is the main Post offlce?

12. Why do we have Special Delivery?

13. Why do they sort the ma1l?

14. What is the Dead Letter of 1 ice?

15. How does the postman know where to take the letters?

16. How can we help the postman?

(b) Storles composed by the children, written by them, and put into booklets.

ON OUR WAY

Skippity, skip to the cars,

Bang, bang went the doors,

Off to the Post office, Through the town we rode.

Slower, slower went the cars. The cars stopped.

Bang, bang went the doors.

Up, up the steps

Through the big door,

Around wo looked. 
We saw many, many things.

We saw a stamp machine.

We saw many pugoon holes where they sort the mail.

We saw something that looked like a sliding board.

It was a chute for packages to slidie down.

We heard something say, "Peep, peep :"

We looked around and saw boxes of baby chicks.

We saw many, many, ma1l bags.

We saw the Special Delivery cage.

We saw a man in another cage.

He was seling stamps.

Stanley bought some stamps.

We saw letters come through the letter slot.

We saw the counting machine.

The visit to the Post Office was interesting.

\section{THE CANCELIING MACHINE}

The cancelling machine cancels the stamp so no one else can use it again.

Burr! Burr! Burr ! went the machine.

The letters went figing through the machine.

They went so fast one letter had an accident.

The letter was torn.

The man had to pull the letter out of the machine and mend the envelope.

We think the cancelling machine should have some safety rules.

\section{THE PIGEON HOLES}

There were many, many plgeon holes in the Post office.

The pigeon holes are used to sort mall. Each pigeon hole had the name of a sate. Some pigeon holes had the name of a city. There were big cities like New York and Chicago.

After the letters are sorted they are put into the ma1l bags.

Then the mall bags are put on the truck and taken to the train.

Away they ride down the track to another state or city. 
The big chute is for packages to slide down.

The big chute is like a sliding board.

The packages slide, slide, slide.

There are big packages and little packages.

When packages are not tied tight they come $1008 \theta$.

Be sure your package is tied tight.

\section{Q. Art:}

1. Draw plcture to 11lustrate stories, poems and riddles.

2. Draw pictures to 1llustrate activities experienced on trip, in playing Post office, and various ways of carrying ma11.

3. Draw pictures to answer questions.

4. Lettoring signs.

H. Industrial Art:

1. Construction of a Post Office.

2. Make the postman's uniform, cap and bag.

3. Make paper money.

4. Make ma11 boxes.

5. Make pigeon holes.

6. Make stamps.

7. Make windows for stamps, parcel post, and general delivery.

I. Mus 1c:

The song terial was taken from the second grade outine in the Courso of Study In Music for the Loulsville Public Schools. J. Test:

An objective test of 100 questions was given at the end of $\mathbf{s i x}$ weeks. The 
reliability of this test by the

Spearman Brown Formula is .81士.045.

Following is a copy of the test.

Completion:

Directions: F1ll in blanks with the correct word.

Example: Letter are written on paper.

1. The postman brings our

2. The stamp is on the

3. The postman has a suit.

4. The postman has a hat.

5. We bought at the Post Office.

6. There are many at the Post office.

7. We went to the Post Office.

8. An stamp costs six cents.

9. The packages silde down a

10. The letters are sorted in the

11. The cancelling machine the stamp.

12. The letters come through a

13. Two cent stamps are

14. A stamp costs ten cents.

15. The biggest Post office is in

16. Packages that come untied are sent to the room.

17. When a letter is addressed wrong it goes to the room.

18. In the Far North the mail is carried on

19. In the South Seas they have postmen. 
20. Mail that is carried by horse-back

is called the

21. To send a letter by Pony Express it would cost dollars.

22. Three cent stamps are

23. Special Delivery stamps are

24. After the letters are sorted they are put in mail

25. After the ma1l is put in ma1l bags it 1s put on the ma1l

26. I am a letter. I want a stamp. I need a stamp.

27. I am a postal card. I want a stamp. I noed a stamp.

28. I am a letter. I am going to be sent by a1r ma11. I need a stamp.

29. I am a letter. I must go in a hurry. I need a stamp.

30. The postman's bag is

31. The mall trucks are

32. The mall boxes on the corner have printed on them.

33. All mall mast be delivered on

34. Packages should be tied

35. You should use knots for packages.

36. No one can go inside of the train.

37. The postman is a very man.

38. The postman is our

39. The air mail stamp is

40. The Post Office dead package room. the peckeges in the 
Yes or No.

Directions: Write yes or no by each sentence. If the sentence is correct, write yes. If it is not corroct, write no.

Example: The sky is green. No.

1. The postman wears a green sult.

2. You need a two cent stamp on your letter if it goes out of town.

3. The postman has a brown bag.

4. Three cent stamps are purplo.

5. The postman carries a whistlo.

6. The mall trucks are blue.

7. You should use square knots when tying packages.

8. Some mail goes on boats.

9. Every one goes to the Post office for their mail.

10. In the South Seas they have swimming postmen.

11. In the Far North they usemail-sleds.

12. The mailman rides on the mail-sled.

13. When it is very cold the dogs wear shoes.

14. All of the mail in the North is carried by dog sleds.

15. The swiming postmon carry the mail on a stick.

16. The swimming postmen are in the Far North.

17. It cost three cents to send a letter by Pony Express.

18. One of the Pony Express riders was named Buffalo Bill. 
19. Some mail is carried on boats.

20. Some mall is carried on trains.

21. A Speclal Delivery stamp costs 15 cents.

22. R.F.D. means city ma11.

23. C.O.D. means collect on delivery.

24. The cancelling machine cancels the stamps.

25. Some mail is carried by airplanes.

\section{Multiple Choice:}

Directions: Draw a ring around the right answer.

Example: A ten cent stamp is (red, blue purple, yellom.

1. A two cent stamp is (red, blue, Yellow, purple, green).

2. A one cent stamp is (black, blue, green, orange, purple).

3. An airmall stamp is (blue, orange, yellow, red, green).

4. The postman's bag is (blue, black, brown, yellow, red).

5. The postman's sult is (blue, brown, gray, white, black).

6. The Special Delivery stamp is (green, purple, yellow, blue, red).

7. The cancelling machine cancels the (letter, address, stamp, date).

8. The Post office is a big (school, house, bullding, library, store).

9. Collect on delivery is the same as (R.F.D., C.O.D., S.P., U.S.).

10. The postman brings us (bread, letters, thread, flowers, apples). 
11. The three cent stamps are (white, purple, blue, orange, yellow).

12. The mail in the Far North is delivered by (sleds, ships, ponies, swimmers, boys).

13. The blggest Post Office is in (New York, Chicago, St. Lou is, Hollywood, Cleveland).

14. Packages that come untied ate (thrown away, put in the deed package room, put in the dead letter-room, put in mail bags, sent to (hicago).

15. The postman's hat is (black, red, blue, yellow, brown).

16. An air-mail stamp costs $(4,5,6,9,8)$ cents.

17. A Special Delivery stamp costs $(15,20$, $10,9,5)$ cents.

18. At the Post office we buy (bread, books. stamps, apples, candy).

19. If a letter goes out of the city, it must have a $(2,4,5,3,6)$ cent stamp.

20. If you ma1l a postal card it neods a $(2,3,4,1,6)$ cent stamp。

21. If you ma1l letter in the city it needs a $(3,2,6,1,5)$ cont stamp.

22. A three cent stamp and a two cent stamp will cost $(6,7,5,3,2$,$) conts.$

23. If you buy two three cent stamps they will cost $(7,6,6,2,4)$ cents.

24. If you buy five one cent stamps they will cost $(6,5,2,1,3)$ conts.

25. If you buy a one cent stamp, a three cent stamp, and a two cent stamp they will cost $(6,4,3,2,7)$. 


\section{Matching:}

Directions: Draw a line from the words to the right picture.

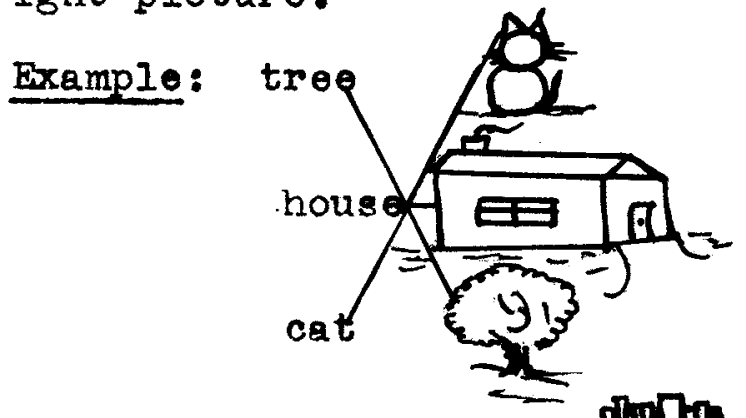

1. A letter.

2. A mail bag.

b.

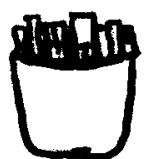

a.

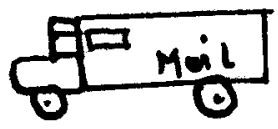

3. A ma1l truck.

4. A stamp.

5. A ma1l plane.

d.

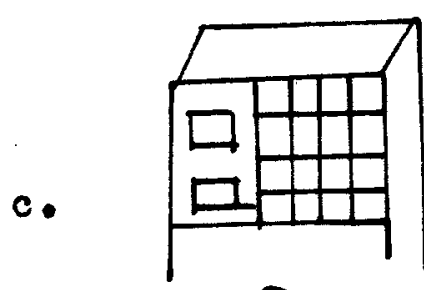

c.

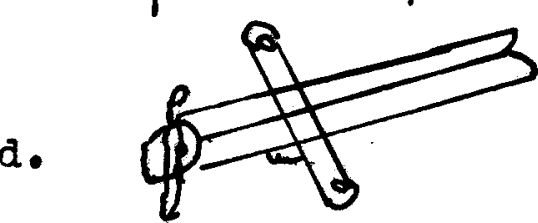

6. A postman.

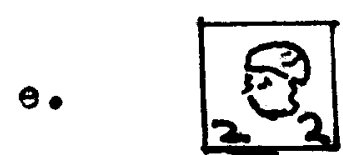

7. The Post office.

8. The postman's bag.

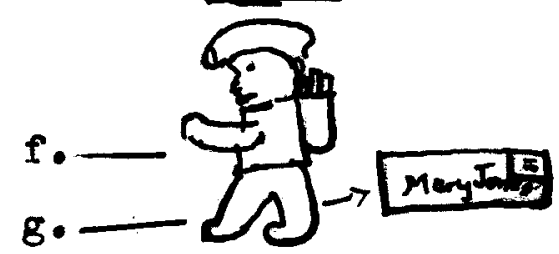

9. A letter box.

10. The postman's cap.

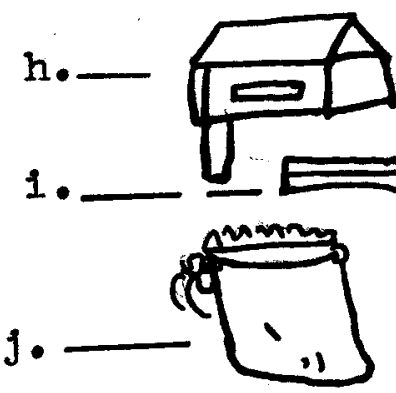


Ker for questiens on the Post Office Unit

Completion

1. mall

2. letter

3. blue

4. blue

5. stamps

6. pigeon holos

7. Post offico

8. air mail

9. chute

10. Post Office

11. cancels

12. slot

13. red

14. Special Delivery

15. New York

16. dead package

17. dead letter

18. sleds

19. swimming

20. pony express

21. 5

22. purple

23. purple

24. bags

25. trains

26. $2 \phi$

27. $1 \%$

28. $6 \notin$

29. Special Delivery

30. brom

31. green

32. U.S.Ma1I

33. time

34. tightly

35. square

36. ma1l

37. busy

38. frlend

39. orange

40. se11:
Yes or No

1. No

2. No

3. Yes

4. Yor

5. Y०8

6. No

7. Yos

8. Yes

9. No

10. Yes

11. Yes

12. No

13. Yes

14. No

15. Yea

16. No

17. No

18. Yes

19. Yes

20. Yos

21. No

22. No

23. Yos

24. Yes

25. Yes
Mult1ple Cholce

1. red

2. groen

3. orenge

4. brown

5. blue

6. purplo

7. stamp

8. bullaing

9. C.0.D.

10. letters

11. purplo

12. sleds

13. New York

14. doad package

15. blue

16. $6 \%$

17. 10

18. stamps

19. 3

20. 1

21. 2

22.5

23. 6

24. 5

25. 6

\section{Matching}

1

2.

3. b

4.

5. d

6. $\mathrm{f}$

$7 . \quad \mathrm{c}$

8. a

9. h 
IV. Outcomes of the Unit:

As observed by the writer, the attitudes gal ned during the unit of the Post Office were as follows:

1. An appreclation of what the Post Office means in the community.

2. How to work together in a cheerful and helpful way in a group.

3. Better attitudes toward habits of neatness, courtesy, and fair play in working together.

4. A desire to evaluate own efforts as compared with the group.

The information obtained pertaining to the things observed and studied during this unit covered the following points:

1. The proper process of preparing letters for malling.

(a) How to write the name of the state, streot and number, and city.

(b) The necessity of writing plainly.

(c) Where to put the stamp.

(d) Where to put the return address.

2. How mall is handled in the post office.

3. How mall is delivered.

4. The existence of the dead letter and dead package department, mural ma1l, and air mail.

5. How to wrap packages for ma1ling. 


\section{Bibliography:}

\section{Teacher's}

Normal Instructor (magazino) Fobmiary, 1927, and February, 1930 .

Poems for Any Day, Primary Grades, Loùisvilie Public Schools.

Storm, G.E., The Social Studies in the Primary Grades, Lyons and Camahan, Chlcago, III., 1931.

The Clasroom Teacher, Volume 4., The Classroom Teacher, Inc., ChIcago, IIl., 1928 .

The Grade Teacher (magazine) February, I930 and February, 1933.

U. S. Postal Guide (Official), Issued by U. $s$. Post offlice Department, July, 1932, Washington, D.C.

B. Children's

Dopp, Elizabeth; Bobby and Betty with the Workers; Rand, MoValiy \& Company, Chicago, Ill.

Dyer and Brady; The Merrill Readers-F1 rst, Charles E. MerriII company, Chlcago, III.

Elson and Gray; Elson Bas1c Reader, Book II; Scott, Foresman \& Company, Ch1cago, III.

Freeman, Storm, Johnson, French; Child Story Reader, Primer and First Reader; Lyons and Carnahan, ChIcago, III.

Gates and Huber; The Work - Play Book, Peter and Peggy, Primer; Macmillan Compan, New York. 
Geckes, Skinner, Wi thers; Trips to Take, Johnson Publishing Company

Hardy, Marjorle; New Stories, Wheeler Publishing Company, Chicago, Ill.

H111, Helen and Maxwell, Violet; Charlie and His Puppy Bingo, The MacMiIIan Company, New York.

Lynch, Maude; Billy Gene and His Friends, Ginn \& Company, ChIcago, III.

Olmstead, Emma; Ned and Nan in Holland, Row, Peterson Company, New York.

Ringer, E.H. \& Downie, L.C., Home, Citizenship Reader, Lippingcott Company, ChIcago, III. Serl, Fmma; In Rabbitville, American Book

Suzzallo, Freeland, Mclaughlin, Skinner; Fact and Story Roader Primer, American Book Company, CInctnnati, ohio. 
Tippett, James S.; Busy Carpenters, World Book Company, Yonkers-on-Hudson, New York.

T1ppett, James S.; I Iive In a City,
Harper Brothers, 
APPENDIX B

TRADITIONAI TEXTBOOK PROCEDURE 


\section{APPENDIX B}

Traditional Method:

The traditional textbook method was carried on in the IA-2B Class at the Longfellow School, Loulsvilie, Kentucky. The writer carried on this method as well as the activity program. The traditional method was carried on from September, 1937, through January, 1938. The same tests were administered to this group as to those working under the activity program. These children wore tested at the beginning of the experiment and at the close of the experiment. The length of this experiment was sixtten weeks.

This group of chlidren had a definite schedule to follow each day. Following is the schodule:

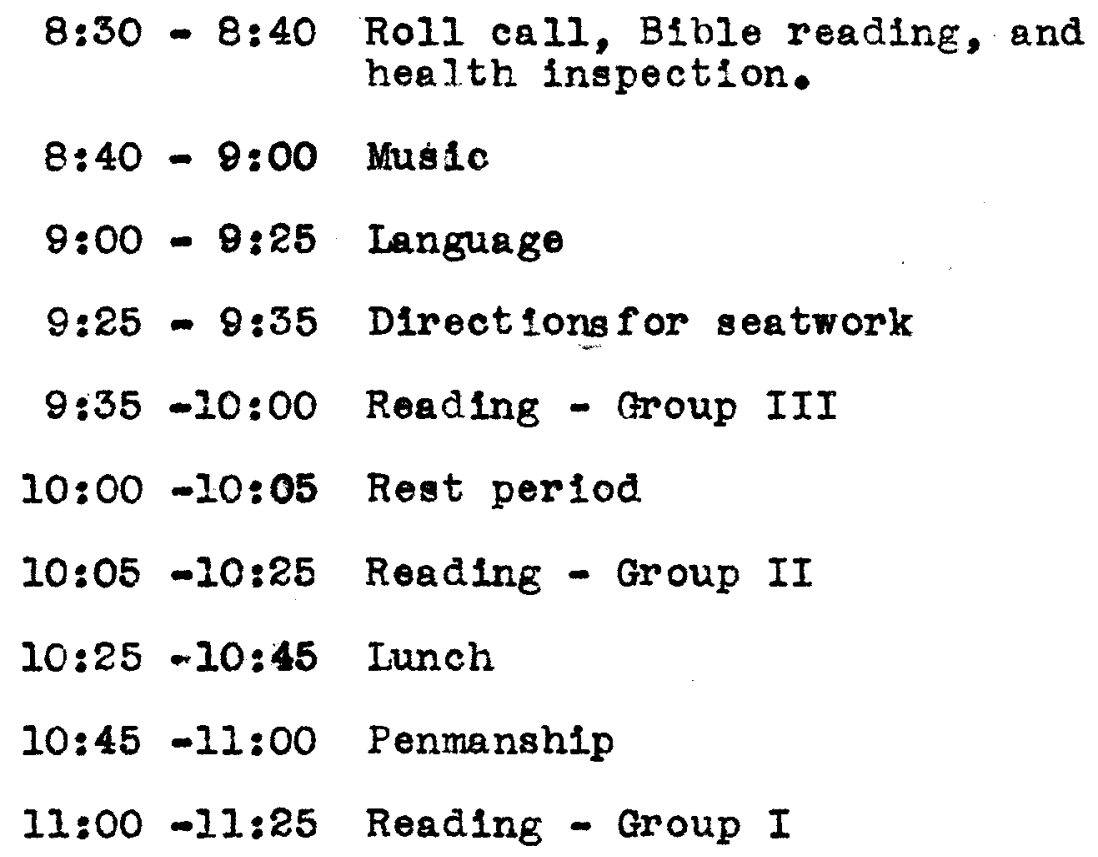




$$
\begin{aligned}
11: 25-11: 40 & \text { Spelilng } \\
11: 40-12: 00 & \text { Play time } \\
12: 00-12: 20 & \text { Ar1thmet1c - Group I } \\
12: 20-12: 40 & \text { Arithmet1c - Grou II } \\
12: 40-1: 05 & \text { Art } \\
1.05-1: 25 & \begin{array}{l}
\text { Safety Counc11 - (Monday) } \\
\text { Nature Study - (Tuesday-Thursday } \\
\text { Industrial Art - (Wednesday) } \\
\text { Story Hour - (Friday) }
\end{array}
\end{aligned}
$$

The class was grouped into three groups according to their reading ability. These grouplngs were based on the opinion of the previous teacher, the writer's general observation of the children during the recitation and study periods, and upon the results of the Metropolitan Achievement Tost (Section on reading).

\section{TABLE XXXII}

ABILITY GROUPINGS FOR READING TAKEN FRON THE METROPOLITAN ACHIEVEMENT TEST

\begin{tabular}{lccc}
\hline & Group I & Group II & Group III \\
\cline { 2 - 4 } Range & $11-25$ & $7-9$ & $2-6$ \\
Mean & 17.7 & 8.0 & 4.57 \\
Standard Deviation & 5.34 & 1.07 & 1.76 \\
\hline
\end{tabular}

From the Metropolitan Achlevement Test scores (Appendix "C") the writer grouped the children into three groups. Group I had six members, Group II had seven members, and Group III had seven nembers. The ranges, means, and standard deviations are given in the above 
table. Each group had a work-typereading lesson everyday. The time limit of these reading lessons was twenty-five minutes.

Books Used by Three Ability Groups of Second Grade Chllaren:

Group I (Superior)

1. Pennell, Mary E., Playing With Pets, A Pre-Primer. GInn and Company, Chicago, 1932.

2. Pennell, Mary E, and Cusack, Allce M., Frolic and Do-Funny. Ginn and Company, ChIcago, 1932 .

3. Stone, Clarence Ro, Tom, Jip and Jane. Webster Publishing Company, St. Louls. 1932 .

4. Elson, $W_{\bullet} H_{\bullet}$, Runkel, L.E., Gray, W.S., Tho Elson Besic Readers Primer. Scott, For seman and Company, Chicago. 1930 .

5. SerI, Erma., In Rabbltville, American Book Company, Chicago, I930.

6. Serl, Emma , Work-A-Day Doings on the

Farm. Silver, Burdett and Company, Chicago, 1916 .

This group read all of these books. Group II (Average)

1. Playing with Pets - the whole book.

2. Frolic and DeFunny- the whole book .

3. Tom, Jip and Jane - the whole book.

4. In Rabbitvilie - the whole book.

5. Work - A -Day Doings on the Farm - the 
Group III (Low)

1. Playing With Petg - whole book.

2. Frolic and Do-Funny - whole book.

3. Tom, J1p and Jane - whole book.

4. Elson Primer - whole book.

Group I read one story each day. Group II read one story each day during the liast four weeks of the experiment. Group III read only one or two pages orally a day and during the last four weeks increased this to three or four pages.

After completing the first three books mentloned for Group I, they could read sllently. Methods of presenting these reading lessons are as follows:

A. Preparation:

1. The introduction - The function of this introduction was to make the child interested and eager to read the material. This introduction sometimes consisted of questions, the telling of a story similar to the one to be read using different characters, and different surroundings, pictures, poems, or conversation.

2. The motive - A motive question to bring out the main idea of the story or for the unit of the story to be read during one period.

3. Mastery of difficulties - Universal difficulties were selected by the teacher and $-184-$ 
presented before the silent reading period.

4. Setting-up standards - In order that definite habits of good silent reading be developed the teacher had children recall the habits which they needed to keep in mind. These habits were printed on a small chart. They are as follows:

1. Sit back in your chair.

2. Hold your book up.

3. Read with your eyes.

4. Help yourself with new words.

5. How to make use of the table of contents.

5. Recall of motive-Sometimos if considerable time had been consumed in the development of difficulties, the motive for reading was recalled.

B. Silent Reading:

During the silent reading of the story, the teacher was busy helping the children with their difficulties and correcting all undesirable habits.

C. Enjoyment of the story and the check-up of slient reading:

In addition to the motive question, other questions were given in order to be sure that the children had comprehended the thought and mastered the mechanics. At the close of the lesson, questions calling for drill which helped to $f 1 x$ the vocabulary were given. The following way were used in securing 
this drill.

1. The children had to point to, or framewth their hands, the sentence, phrase, or word which told a certain thing.

2. The children read the sentence or phrase which told a certain thing.

3. An organization question was given whose answer was a group of sentences.

4. Had the children find the most difficult words in the lesson.

5. Had the children read the part they liked best.

6. Had the children read funny, exciting, or sad parts of the story.

7. The teacher began a sentence and had the children find that sentence and finish it.

8. Had children read as far as they need to In order to tell a certain part of the story.

9. Had a number of children read a conversational part to see which could best represent the character.

10. Had children find all the words beginning w.th the sound of "wh" or any other one.

11. Had children find the words belonging to the "it" family.

All of these were not used in one lesson. These were ased during the whole term. 
D. Follow-up work:

This work was varied, sometimes it consisted of 1llustrating or cutting the main ideas of the story, its characters or incidents. Sometimes a small group of children would practice reading aloud portions of the material, taking the part of different characters, or dramatizing the story. This was individual work in reading for the betwoen recitation perlod.

Group II and Group III did mostly oral reading. The following steps were used in these lessons:

A. Preparation:

1. Introduction and motive - Same as for Group I.

2. Mastery of universal difficultiesThese difficulties were printed on flash card strips and learned before starting to read.

3. Development of standarda - These standards were:

1. Nake the audience see the picture.

2. Make the audience experience the funniness, sadness, or excitement of certain parts of the story.

3. Make tho audience feel that the real character is talking.

4. Read with pleasing, easily understood volces. 
5. Enunciate clearly and pronounce the words correctly.

6. Read smoothly.

B. Oral reading:-

The type of oral reading done depended upon the story read and the needs of the group. The following types were used.

1. Ine by Iine reading through questions.

2. Reeding orally the entire page.

3. Reading to answer questions which called for the pictures, emotional passages, and conversation.

4. Reading to take the parts of characters.

5. Reading for dramatizing with the book.

Group II used the above mothod for the first twelve weeks and the first method mentioned for the last four weeks. Group III used the above method the entire sixteen weeks of the experiment.

The following remedial measures were used to aid the children in overcoming their difficulties:

1. For lack of interest in reading:

(a) Teacher found out the child's interests and selected easy reading relating to those interests.

(b) Trled to make the child feel his need of reading to carry on his own interests.

(c) Surrounded the child with attractive material relating to his interests. 
(d) Make the child confident of his ability to read the material by referring to his success in other ines.

(0) Commended the slightest sign of Improvement.

2. For Lack of control over words:

(a) Selocted and formulated stories relating to the child's interests, using the same vocabulary in many different situations.

(b) Before the child attempted to read ho was helped to ster words which would cause the greatest difficulty.

(c) Gave much drill upon the words in context.

(d) Had the child find all the words on the page belonging to the "1ght" family or the "it family; all words beginning with a certain sound or letter, as "I".

3. For lack of comprehenston:

(a) Gave the child a small amount of reading material sulted to his interests and ability.

(b) Had child read a paragraph and then tell what the paragraph was about.

(c) Had the child read the material and name the pictures seen.

(d) Had the child find phreses, words, or sentences that told certain things. 
Once a week the children had a recreatory reading period during which they read aloud or told storles they had prepared outside of school. These books were obtained from the room library.

The class was divided into two groups for arithmetic. These groupings were based on the opinion of the previous teacher, the writer's general observation of the children during the recitation period the first week of the experiment, and upon the results of the Metropolitan Achlevement Test (Section for arithmetic).

\section{TABLE XXXIII}

ABILITY GROUPINGS FOR ARITHMETIC TAKEN FROM THE METROPOLITAN ACHIEVEMENT TEST

\begin{tabular}{lrc} 
& Group I & Group II \\
\cline { 2 - 3 } Rango & $13-22$ & $5-13$ \\
Mean & 16.70 & 9.30 \\
Standard Deviation & 4.01 & 2.73 \\
\hline
\end{tabular}

From the Metropolitan Achievenent Test 3 cores (Appendix "C") the writer grouped the children into two groups, each group having ten members. The ranges, means, and Standard deviations are given in the above table.

During the semester the one hundred basio adition facts were taught. First, fifteen addition facts were taught in order to establish the addition 
concept (textbook 11.25-49) I. Then the fifteen corresponding subtraction facts were taught in order to establish the subtraction concept (Number StoriesBook Iwo, pp.56-78). After these thirty facts had been taught, the remaining corresponding addition and subtraction facts were taught. Number Stories, Book Two, by J.W. Studebaker and Others was used as a text book. The following pages were covered during the semester: pp. 7-61, 68-196, 228-230. The additive method in subtraction was taught. Flash cards wore used for drill. Various games involving the basic combinations were played.

\section{Samples:}

1. Guessing Game.

One child eaid; "I am thinking of two numbers that make $7 . "$

Another child sald; "Are they 5 and 2 ?" and $2 . "$

First child; "No, they are not 5

Another child; "Are they 6 and 1?"

First child; "Yes, they are 6 and 1:"

The child guessing the correct numbers

is the next one to select two numbers.

2. Fishing.

Place flash cards $\left[\begin{array}{l}2 \\ 3\end{array}\right] \begin{aligned} & 4 \\ & 1\end{aligned}$ on floor.

Let each child pick one up. Each child

1. Studebaker, J.W., and Others, Number Stor 1es-Book Two. Scott, Foresman and Company, Chicago, 1933. 
should be able to give the correct answer to the combination on the card that he plckod up. This gamo was variod by lotting chlldren gather leaves and pumpkins. Examples like these were mastered:

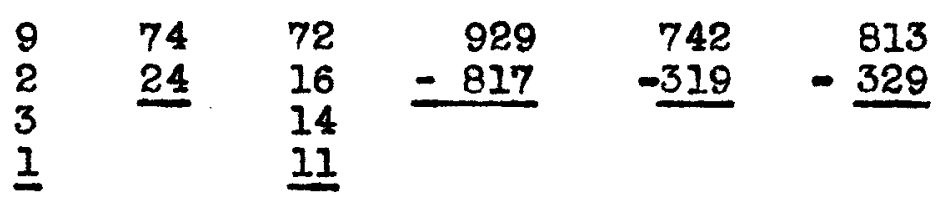

Number stories devised by the toacher wore solved - a few examples:

1. If you would like to have a cup of soup and a bun for lunch, how much would your Iunch cost? (Soup 2ф; Buns 2ф)

2. Jane has 2 baby chicks and Dick has 4 baby chlcks. How many chlcks do they both have?

3. Billy had $4 \notin$ and he noeded $8 \not$ for a bottle of milk. How many more cents does he need?

The spolling material. was taken from the second grade textbook entitied, Learning to Spell, by Coleman, Donovan, Frazier and Stoddard ${ }^{2},(p p .1-42)$. The procedure used was three new words a day and a test on Friday. Each word was studied, pronouncing it,

2. Coleman, W.H., and Others. Learning fo Spell-Second Grade. Hail \& McCreary Company, Chicago, 1934. 
giving a sentence using the word, and writing the word.

The writing, drawing, industrial art, misic, health, safety, and nature materlals were taken from the second grade outline in the course of Study in these subjects for the Louisville Public Schools. 3 .

The language periods were spent in con-. versation regarding trips and experiences the chlldren had outside of school hours. Topics in season were discussed, such as leaves and treos in the fall, Thanksgiving,Christmas and winter activities.

3. Zaner and Bloser. Correlated Handwriting Compendium II. Zaner and BIoser PubIlshing Company, Columbus, Oh10. Entire book.

Curriculum Committee. A Tentative Course of Study In Fine and Industrial Arts Education for the Elemen-

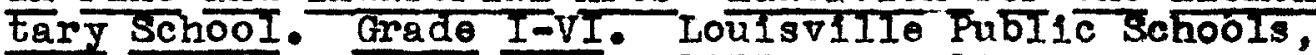
Loulsvil1e, Kentuck y, June, 1933 . pp.7-19.

Curriculum Committee. Report of Music Committee, Kindergarten, First and Second Grades. Loulsvillo Public Schools, Loulsvilie, Kentucky, May, 1932. pp. $37-49$.

Mimeographed sheets were supplied by the respective Supervisors for health, safety, and nature study. 
During this semester no trips were taken to provide interesting material for the children. No construction was carried on in the school room. The children sat quietiy at their desks and, as the writer sees 1t, passively recelved what was prescribed. The atmosphere of the school was quite formal. There was an abundance of time given to arill on all subject matter. These drills were not "felt" needs of the pupils, but merely parts of the teacher's assignment. Review and drill are a natural part of the I1fe activities of most people. They are a natural part of the school work of an activity program too. The essential difference between reviow and drill in an activity program and in the traditional method of teaching is this: In the activity program, the pupils feel the need for the review or see the desirability for the drill before such work is done. By the traditional method reviews and drills originate entiraly with the teacher. 
APPENDIX $\quad \underline{C}$

THE DATA 


\begin{tabular}{|c|c|c|c|c|c|c|c|c|c|c|c|c|c|c|}
\hline \multirow{2}{*}{$\begin{array}{l}I \\
P .\end{array}$} & \multirow{2}{*}{$\begin{array}{c}2 \\
196 \\
1936 \\
\text { C.A. }\end{array}$} & \multirow{2}{*}{$\begin{array}{l}3 \\
I . Q .\end{array}$} & \multirow{2}{*}{$\begin{array}{c}4 \\
\text { M.A. }\end{array}$} & \multirow{2}{*}{$\begin{array}{c}5 \\
150 \\
1937 \\
\text { C.A. }\end{array}$} & \multicolumn{2}{|c|}{6} & \multicolumn{2}{|r|}{7} & \multicolumn{2}{|r|}{8} & \multicolumn{2}{|c|}{9} & \multicolumn{2}{|r|}{10} \\
\hline & & & & & $\begin{array}{c}F e b \\
A\end{array}$ & $\begin{array}{c}\text { June } \\
A\end{array}$ & $\begin{array}{l}\text { F. } \\
\text { R. }\end{array}$ & $\begin{array}{l}\mathrm{J} . \\
\mathrm{C} .\end{array}$ & $\begin{array}{l}\text { F. } \\
\text { P. }\end{array}$ & $\begin{array}{l}\mathbf{J} \\
\mathbf{M}\end{array}$ & F. & J. & $\begin{array}{c}F_{0} \\
T\end{array}$ & $0^{\mathrm{J}} \mathrm{JaI}^{\mathrm{J}}$ \\
\hline $\begin{array}{l}1 \\
2 \\
3 \\
4 \\
5 \\
6 \\
7 \\
8 \\
9 \\
10 \\
11 \\
12 \\
13 \\
14 \\
15 \\
16 \\
17 \\
18 \\
19 \\
20\end{array}$ & $\begin{array}{l}6-7 \\
6-4 \\
6-3 \\
6-3 \\
6-1 \\
6-2 \\
6-1 \\
6-1 \\
6-0 \\
6-0 \\
6-0 \\
6-0 \\
6-0 \\
6-0 \\
5-10 \\
5-11 \\
5-10 \\
5-10 \\
5-9 \\
5-6\end{array}$ & $\begin{array}{l}105 \\
108 \\
101 \\
120 \\
129 \\
133 \\
123 \\
123 \\
140 \\
133 \\
127 \\
127 \\
120 \\
94 \\
141 \\
124 \\
128 \\
112 \\
127 \\
130\end{array}$ & $\begin{array}{l}6-11 \\
6-8 \\
6-11 \\
7-6 \\
7-10 \\
8-3 \\
7-5 \\
7-6 \\
8-4 \\
8-0 \\
7-8 \\
7-8 \\
7-3 \\
5-8 \\
8-3 \\
7-4 \\
7-6 \\
6-11 \\
7-4 \\
7-3\end{array}$ & $\begin{array}{c}7-7 \\
7-4 \\
7-3 \\
7-3 \\
7-1 \\
7-8 \\
7-1 \\
7-1 \\
7-0 \\
7-0 \\
7-0 \\
7-0 \\
7-0 \\
7-0 \\
6-10 \\
6-11 \\
6-10 \\
6-10 \\
6-9 \\
6-6\end{array}$ & $\begin{array}{l}6-10 \\
6-5 \\
6-7 \\
7-0 \\
6-10 \\
7-10 \\
6-7 \\
6-5 \\
6-9 \\
6-7 \\
6-9 \\
6-9 \\
6-10 \\
6-9 \\
6-5 \\
6-9 \\
6-10 \\
6-6 \\
6-7 \\
6-5\end{array}$ & $\begin{array}{l}7-2 \\
7-8 \\
7-10 \\
7-8 \\
7-10 \\
8-9 \\
7-8 \\
7-6 \\
7-8 \\
7-8 \\
7-6 \\
7-10 \\
7-10 \\
7-8 \\
7-2 \\
7-10 \\
7-8 \\
7-8 \\
7-5 \\
7-8\end{array}$ & $\begin{array}{r}0 \\
1 \\
3 \\
4 \\
5 \\
14 \\
4 \\
1 \\
3 \\
6 \\
2 \\
3 \\
7 \\
5 \\
0 \\
3 \\
3 \\
5 \\
1 \\
2\end{array}$ & $\begin{array}{r}10 \\
15 \\
11 \\
16 \\
12 \\
16 \\
12 \\
9 \\
10 \\
16 \\
14 \\
10 \\
13 \\
16 \\
11 \\
8 \\
12 \\
13 \\
8 \\
13\end{array}$ & $\begin{array}{l}1 \\
2 \\
0 \\
4 \\
2 \\
1 \\
5 \\
0 \\
4 \\
2 \\
2 \\
2 \\
4 \\
2 \\
2 \\
2 \\
1 \\
1 \\
2 \\
1\end{array}$ & $\begin{array}{l}17- \\
16 \\
6 \\
11 \\
9 \\
17 \\
9 \\
5 \\
8 \\
13 \\
8 \\
5 \\
11 \\
12 \\
8 \\
9 \\
10 \\
6 \\
6 \\
6\end{array}$ & $\begin{array}{l}2 \\
0 \\
2 \\
3 \\
1 \\
1 \\
2 \\
2 \\
4 \\
0 \\
2 \\
4 \\
1 \\
2 \\
0 \\
2 \\
2 \\
2 \\
2 \\
2\end{array}$ & $\begin{array}{r}0 \\
10 \\
2 \\
6 \\
10 \\
9 \\
8 \\
5 \\
9 \\
8 \\
3 \\
4 \\
3 \\
11 \\
2 \\
9 \\
6 \\
8 \\
1 \\
2\end{array}$ & $\begin{array}{r}3 \\
3 \\
5 \\
11 \\
8 \\
16 \\
11 \\
3 \\
11 \\
8 \\
6 \\
9 \\
12 \\
9 \\
2 \\
7 \\
6 \\
8 \\
5 \\
5\end{array}$ & $\begin{array}{l}11 \\
41 \\
19 \\
33 \\
31 \\
42 \\
29 \\
19 \\
27 \\
37 \\
25 \\
19 \\
27 \\
39 \\
21 \\
26 \\
28 \\
29 \\
15 \\
21\end{array}$ \\
\hline$\frac{M}{\sigma}$ & $\begin{array}{r}6.05 \\
.71 \\
.16\end{array}$ & $\begin{array}{r}122: 25 \\
12.40 \\
2.83\end{array}$ & $\begin{array}{r}7.10 \\
.74 \\
.17\end{array}$ & $\begin{array}{r}7.05 \\
.94 \\
.21\end{array}$ & $\begin{array}{r}6.90 \\
.37 \\
.08\end{array}$ & $\begin{array}{r}7.00 \\
.44 \\
.10\end{array}$ & $\begin{array}{r}3.60 \\
3.04 \\
.70\end{array}$ & $\begin{array}{r}12.25 \\
2.58 \\
.59\end{array}$ & $\begin{array}{r}2.00 \\
1.10 \\
.25\end{array}$ & $\begin{array}{r}8.90 \\
3.70 \\
.85\end{array}$ & $\begin{array}{r}1.80 \\
1.08 \\
.25\end{array}$ & $\begin{array}{r}5.80 \\
3.30 \\
.76\end{array}$ & $\begin{array}{r}7.10 \\
3.82 \\
.88\end{array}$ & $\begin{array}{r}26.95 \\
8.35 \\
1.91\end{array}$ \\
\hline$q_{a}$ & .20 & 3.99 & & $\cdot 28$ & & .14 & & 1.20 & & 1.54 & & .93 & & 3.38 \\
\hline$\frac{d}{\sigma_{d}}$ & .00 & .73 & & .00 & & 4.64 & & 5.83 & & 2.34 & & 2.31 & & 3.65 \\
\hline
\end{tabular}

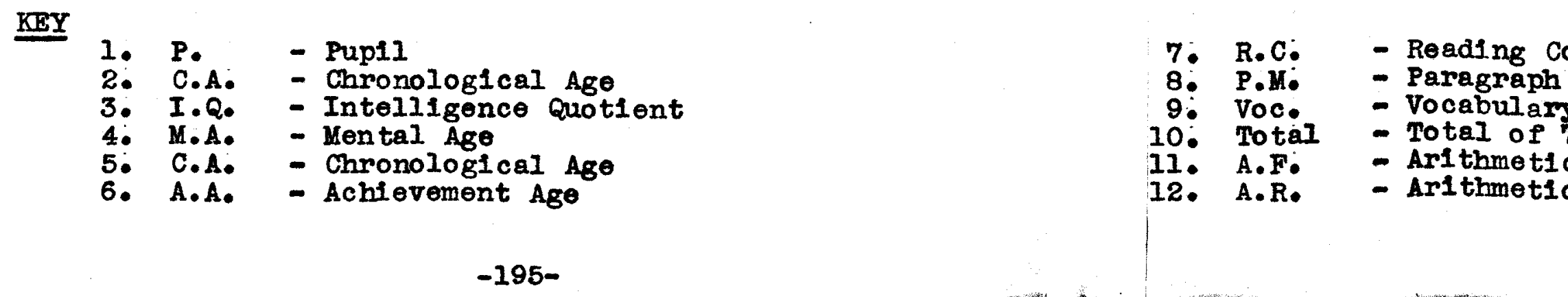




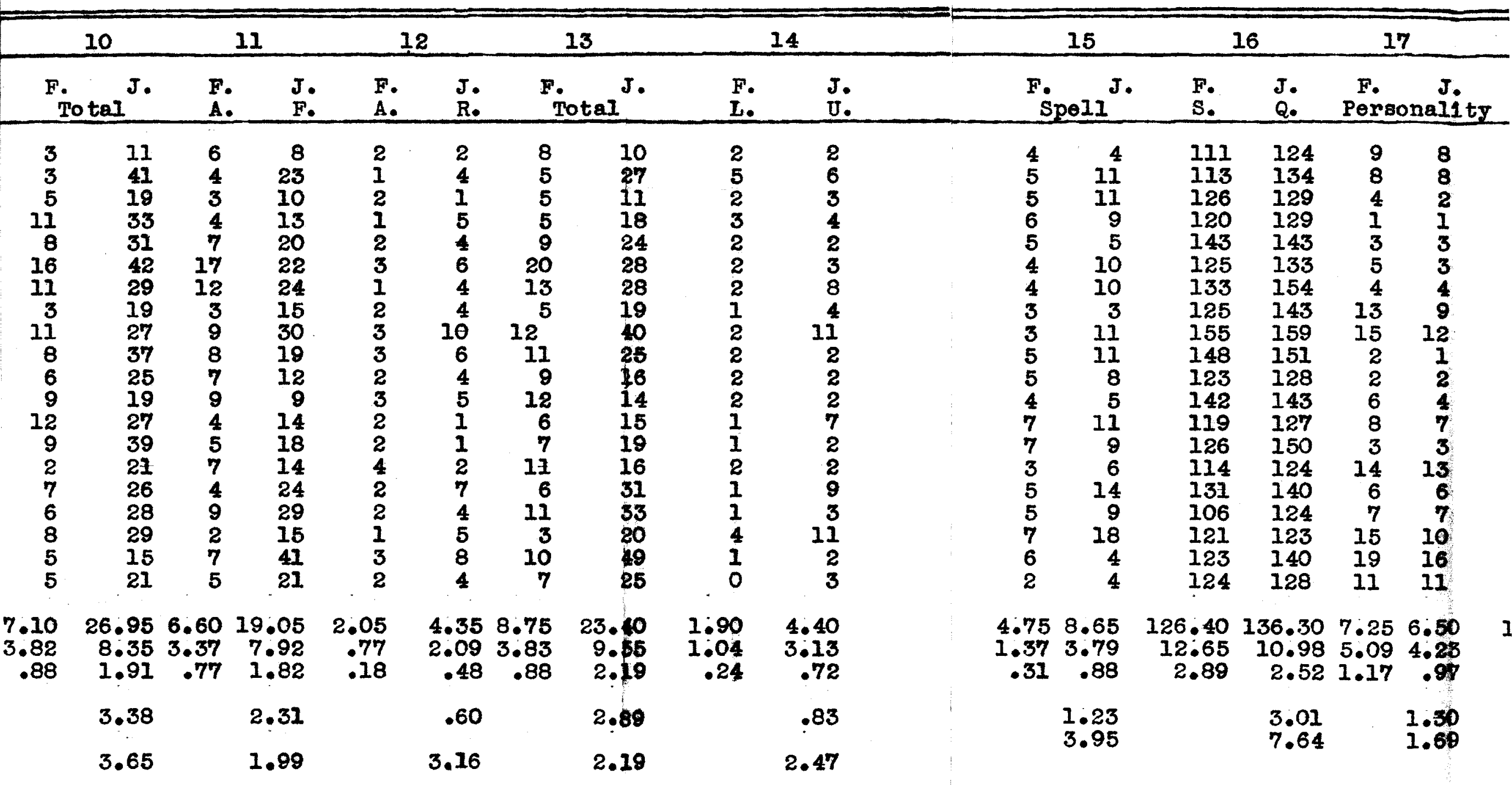

- Reading Completion

- Paragraph Meaning

- Vocabulary

- Total of 7, 8 and 9

- Ar1thmet1c Fundementals

- Arithmetic Reasoning
13: Totàl -.-

14. I.U.

15.

16 :

17 .
Spe11.

S.Q.

Personalit

Coop.
Total of 11 and 12

Language Usage

Speliling

Social Quotient

- Personality

Cooperation

\section{9}

20

21

23 


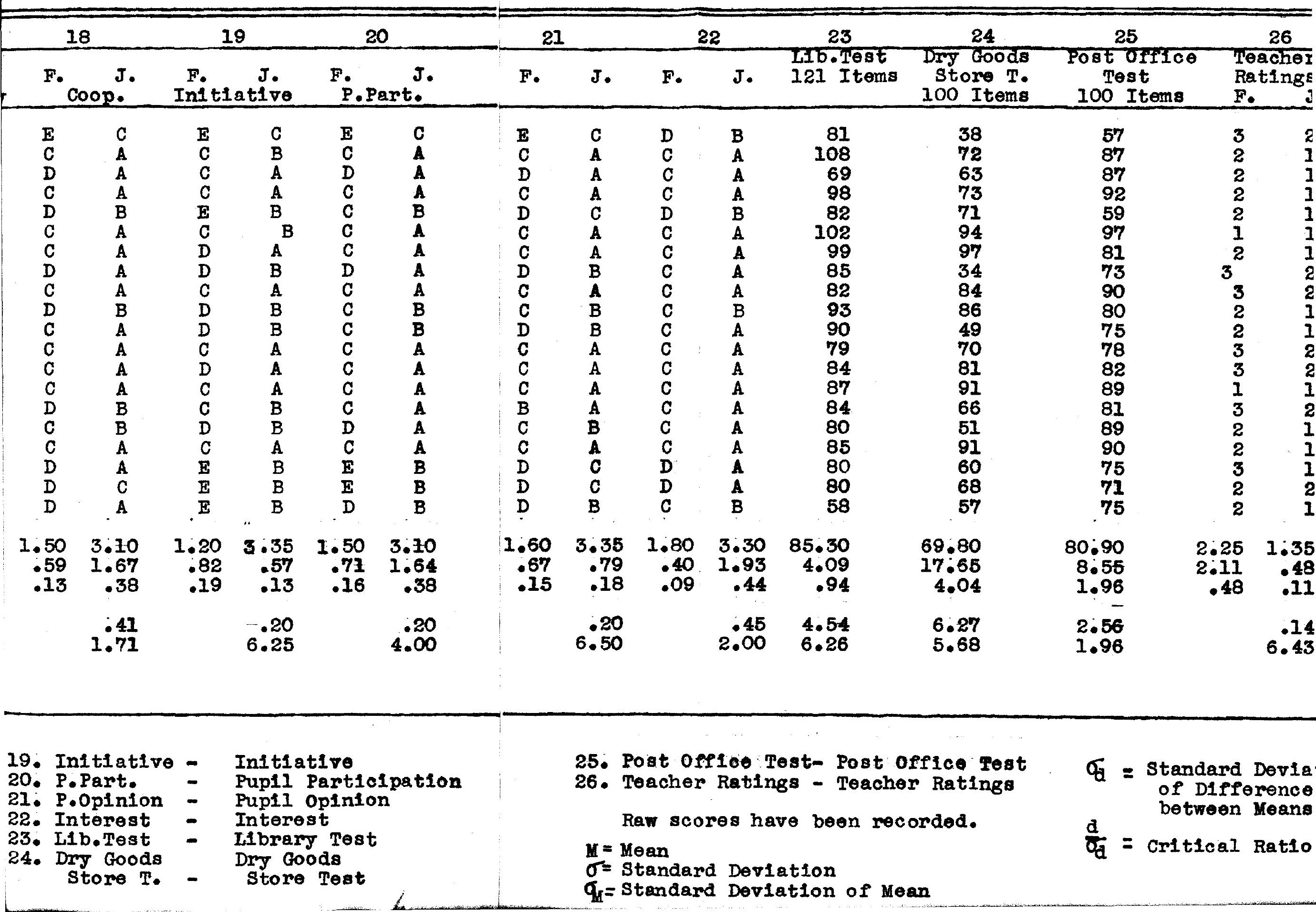


DATA FOR CHILDREN OF TRADITIONAL TEXTBOOK

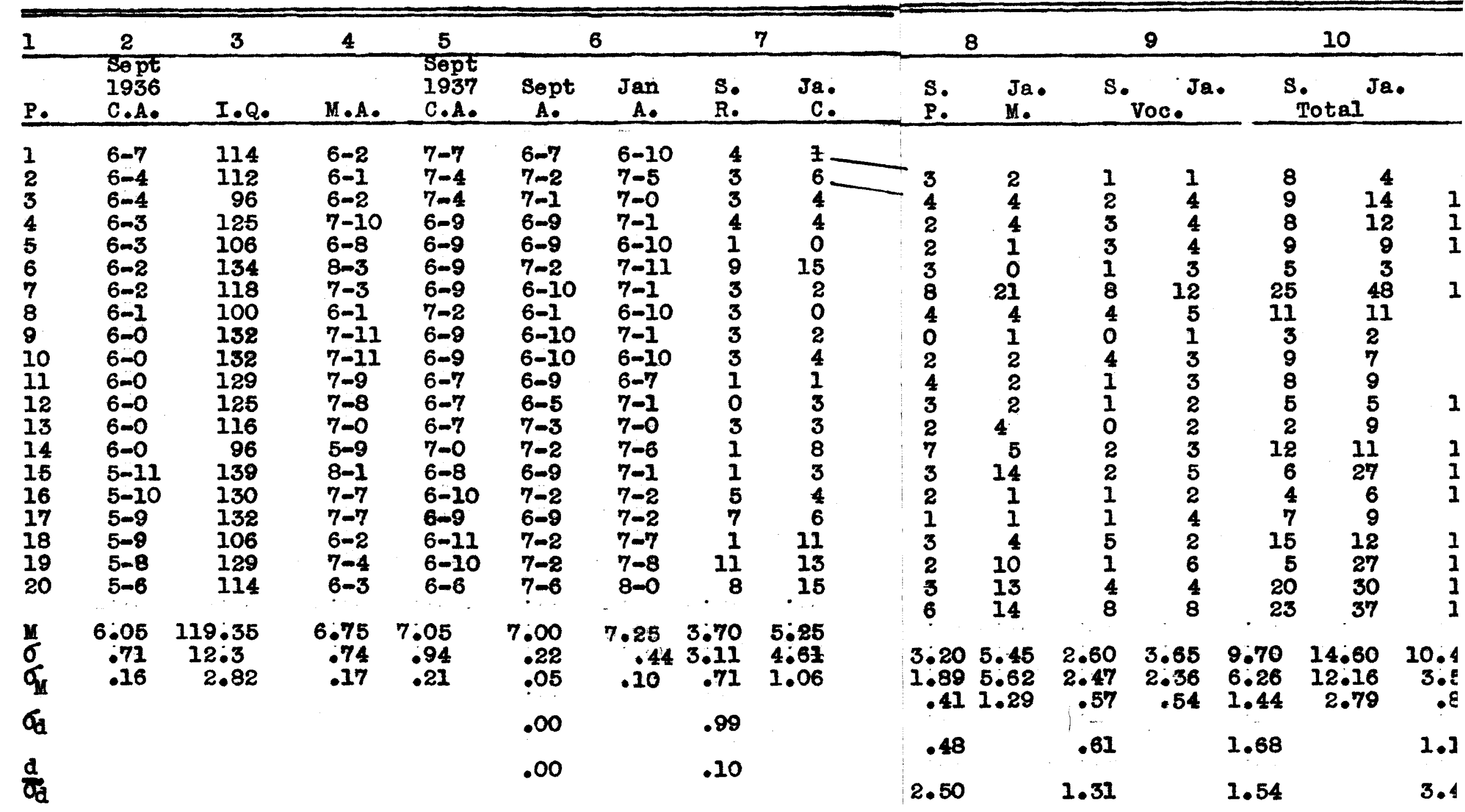


TABIE XXXIV - Cont'd.

PROCEDURE - SEPTEMBER $1937 \quad$ - JANUAFY 1938 TIME SIXTER

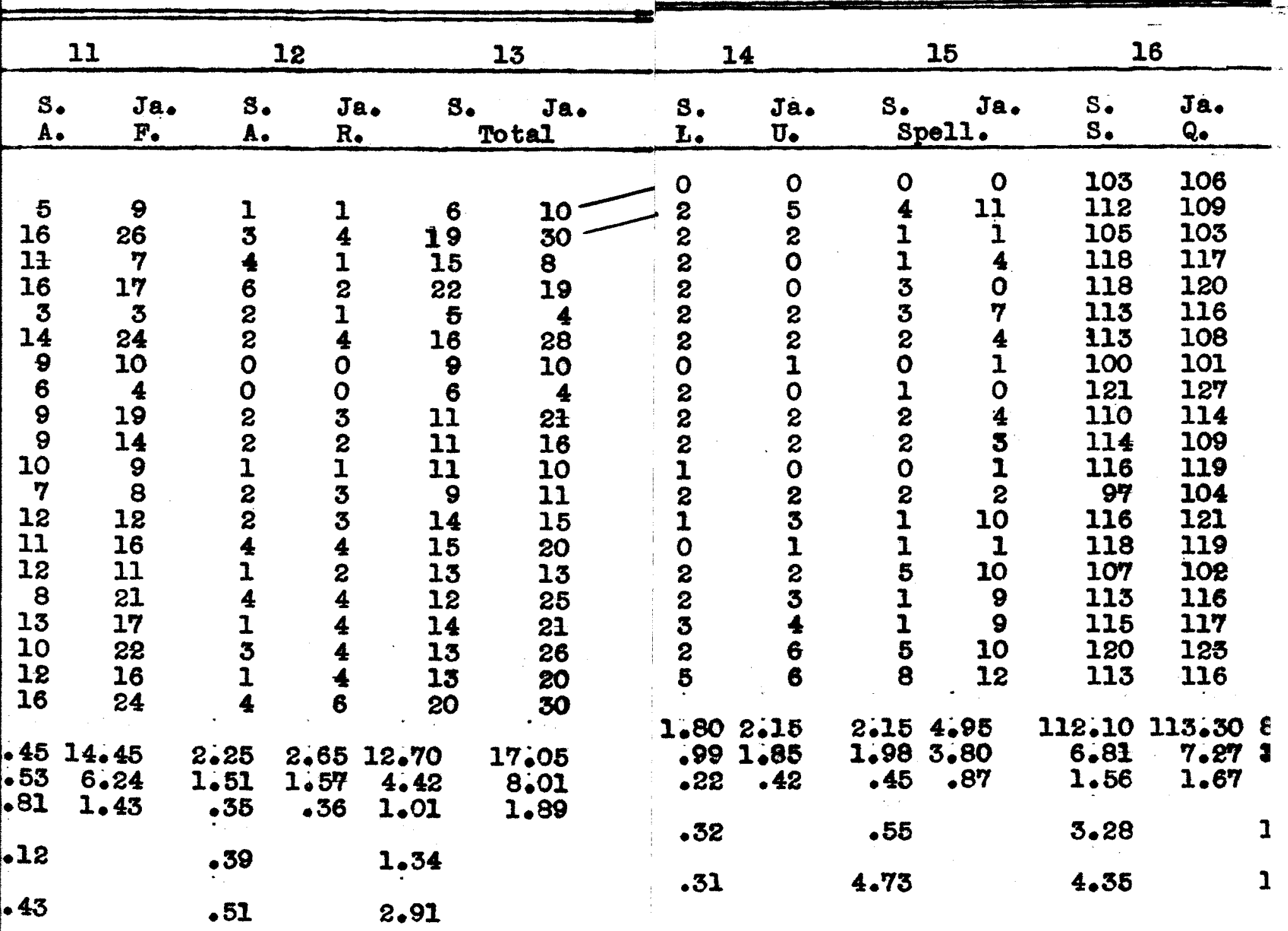




\begin{tabular}{|c|c|c|c|c|c|c|c|c|c|c|c|c|c|c|c|}
\hline \multicolumn{2}{|c|}{17} & \multicolumn{2}{|r|}{18} & \multicolumn{2}{|r|}{19} & \multicolumn{2}{|l|}{20} & \multicolumn{2}{|c|}{21} & \multicolumn{2}{|c|}{22} & \multirow{2}{*}{$\begin{array}{l}23 \\
\text { LIb.1'⿺st } \\
121 \text { Items }\end{array}$} & \multirow{2}{*}{$\begin{array}{l}24 \\
\text { Dry Goods } \\
\text { Store T. } \\
100 \text { I tems }\end{array}$} & \multirow{2}{*}{$\begin{array}{c}25 \\
\text { Post orirce } \\
\text { Test } \\
100 \text { Items }\end{array}$} & \\
\hline $\begin{array}{r}\text { S. } \\
\text { Pers }\end{array}$ & $\begin{array}{r}\text { Ja. } \\
\text { onal1t }\end{array}$ & S. & $\begin{array}{l}\mathrm{Ja} \\
\text { Coop. }\end{array}$ & - S. & $\begin{array}{l}\text { Ja. } \\
\text { Lat1re }\end{array}$ & s. & Ja. & s. & Ja. & s. & Ja. & & & & (e) \\
\hline $\begin{array}{r}9 \\
11 \\
17 \\
9 \\
5 \\
6 \\
5 \\
11 \\
7 \\
7 \\
5 \\
9 \\
6 \\
5 \\
11 \\
15 \\
16 \\
6 \\
8 \\
6\end{array}$ & $\begin{array}{r}9 \\
11 \\
17 \\
13 \\
5 \\
6 \\
5 \\
11 \\
7 \\
7 \\
5 \\
9 \\
6 \\
4 \\
11 \\
13 \\
15 \\
6 \\
8 \\
6\end{array}$ & $\begin{array}{l}\mathrm{I} \\
\mathrm{C} \\
\mathrm{D} \\
\mathrm{C} \\
\mathrm{D} \\
\mathrm{C} \\
\mathrm{C} \\
\mathrm{D} \\
\mathrm{C} \\
\mathrm{D} \\
\mathrm{C} \\
\mathrm{D} \\
\mathrm{C} \\
\mathrm{C} \\
\mathrm{D} \\
\mathrm{C} \\
\mathrm{C} \\
\mathrm{D} \\
\mathrm{D} \\
\mathrm{D}\end{array}$ & 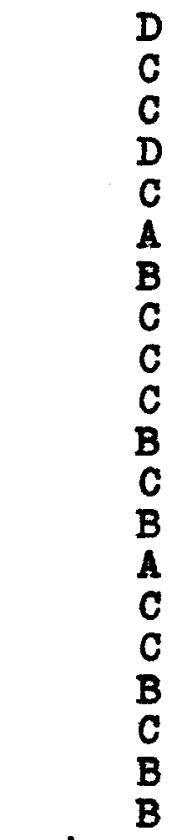 & $\begin{array}{l}\mathbf{E} \\
\mathrm{C} \\
\mathrm{C} \\
\mathrm{C} \\
\mathbf{E} \\
\mathrm{C} \\
\mathrm{D} \\
\mathrm{D} \\
\mathrm{C} \\
\mathrm{D} \\
\mathrm{D} \\
\mathrm{D} \\
\mathrm{D} \\
\mathrm{C} \\
\mathrm{C} \\
\mathrm{B} \\
\mathrm{C} \\
\mathbf{E} \\
\mathbf{E} \\
\mathbf{E}\end{array}$ & $\begin{array}{c}\text { D } \\
\text { C } \\
\text { C } \\
\text { D } \\
\text { C } \\
\text { B } \\
\text { B } \\
\text { D } \\
\text { C } \\
\text { C } \\
\text { C } \\
\text { C } \\
\text { C } \\
\text { C } \\
\text { C } \\
\text { B } \\
\text { C } \\
\text { C } \\
\text { B } \\
\text { B }\end{array}$ & $\begin{array}{l}\mathrm{C} \\
\mathrm{B} \\
\mathrm{D} \\
\mathrm{C} \\
\mathrm{C} \\
\mathrm{C} \\
\mathrm{C} \\
\mathrm{D} \\
\mathrm{C} \\
\mathrm{C} \\
\mathrm{C} \\
\mathrm{C} \\
\mathrm{C} \\
\mathrm{C} \\
\mathrm{C} \\
\mathrm{C} \\
\mathrm{C} \\
\mathrm{E} \\
\mathrm{E} \\
\mathrm{D}\end{array}$ & $\begin{array}{l}\text { D } \\
B \\
C \\
C \\
C \\
A \\
B \\
D \\
C \\
C \\
B \\
C \\
B \\
C \\
C \\
C \\
C \\
C \\
B \\
B\end{array}$ & $\begin{array}{l}E \\
C \\
D \\
C \\
D \\
C \\
C \\
D \\
C \\
C \\
D \\
C \\
C \\
C \\
C \\
C \\
C \\
D \\
D \\
C\end{array}$ & $\begin{array}{l}\mathrm{D} \\
\mathrm{B} \\
\mathrm{C} \\
\mathrm{C} \\
\mathrm{C} \\
\mathrm{C} \\
\mathrm{B} \\
\mathrm{D} \\
\mathrm{C} \\
\mathrm{C} \\
\mathrm{C} \\
\mathrm{C} \\
\mathrm{C} \\
\mathrm{C} \\
\mathrm{C} \\
\mathrm{C} \\
\mathrm{C} \\
\mathrm{C} \\
\mathrm{B} \\
\mathrm{C}\end{array}$ & $\begin{array}{l}E \\
C \\
C \\
C \\
D \\
C \\
C \\
D \\
C \\
C \\
C \\
C \\
C \\
C \\
C \\
C \\
C \\
D \\
D \\
C\end{array}$ & $\begin{array}{l}D \\
B \\
C \\
C \\
C \\
A \\
B \\
D \\
C \\
C \\
B \\
C \\
C \\
B \\
C \\
C \\
C \\
C \\
B \\
B\end{array}$ & $\begin{array}{l}28 \\
79 \\
68 \\
38 \\
50 \\
72 \\
53 \\
22 \\
54 \\
62 \\
49 \\
50 \\
49 \\
80 \\
43 \\
57 \\
28 \\
81 \\
81 \\
93\end{array}$ & $\begin{array}{r}15 \\
33 \\
28 \\
18 \\
30 \\
59 \\
32 \\
8 \\
29 \\
50 \\
20 \\
22 \\
22 \\
50 \\
34 \\
27 \\
43 \\
52 \\
52 \\
59\end{array}$ & $\begin{array}{r}16 \\
33 \\
30 \\
33 \\
30 \\
38 \\
25 \\
17 \\
36 \\
36 \\
33 \\
30 \\
33 \\
38 \\
17 \\
25 \\
29 \\
37 \\
42 \\
38\end{array}$ & $\begin{array}{l}3 \\
2 \\
2 \\
2 \\
2 \\
1 \\
2 \\
3 \\
3 \\
2 \\
2 \\
3 \\
3 \\
2 \\
3 \\
2 \\
2 \\
3 \\
2 \\
2\end{array}$ \\
\hline $\begin{array}{r}8.75 \\
3.44 \\
.84\end{array}$ & $\begin{array}{r}8.70 \\
3.61 \\
.87\end{array}$ & $\begin{array}{r}1: 10 \\
.63 \\
.14\end{array}$ & $\begin{array}{r}2.40 \\
.80 \\
.18\end{array}$ & $\begin{array}{r}1.25 \\
.89 \\
.20\end{array}$ & $\begin{array}{r}2.10 \\
.63 \\
.14\end{array}$ & $\begin{array}{r}1.60 \\
.64 \\
.15\end{array}$ & $\begin{array}{r}2.30 \\
.68 \\
.16\end{array}$ & $\begin{array}{r}1.60 \\
.67 \\
.15\end{array}$ & $\begin{array}{r}2.05 \\
.50 \\
.11\end{array}$ & $\begin{array}{r}1.70 \\
.56 \\
.13\end{array}$ & $\begin{array}{r}2.40 \\
: 47 \\
: 11\end{array}$ & $\begin{array}{r}56.85 \\
19.42 \\
4.45\end{array}$ & $\begin{array}{r}34.15 \\
20.33 \\
4.66\end{array}$ & $\begin{array}{r}30.80 \\
7.26 \\
1.66\end{array}$ & $\begin{array}{r}2: 35 \\
1.97 \\
.45\end{array}$ \\
\hline 1.44 & & .15 & & .26 & & .20 & & .00 & & .14 & & & & & .65 \\
\hline 1.04 & & .66 & & .19 & & .50 & & .00 & & .71 & & & & & .15 \\
\hline
\end{tabular}


BIBLIOGRAPHY 


\section{BIBLIOGRAPHY}

1. Adams, Fay. The Initiation of an Activity Program into a Public School. New York City, Tho Bureau of Publications, Teachers College, Columbia University. 1934.

2. Baldwin, William A. From the 01d to the New Education. Boston, New Fngland Publishing Company, 1930 .

3. Bode, Boyd H. Modern Educational Theories. New York City, The MacMilian Company, 1930.

4. Bode, Boyd H. Conflicting Psychologles of Learning. Boston; D.C.Heath and Company, 1929 .

5. Brusse, B.Bates and Ajer,Fred C., The Activity Program in Action. Dallas, Texas. Banks, Upshaw and Company, 1935.

6. Buckingham, B.R., Reasearch for Teachers. Now York City, Silver, Burdet \& Company, 1926.

7. Burr, Samuel Engle. An Introduction to Progressive Education (The Activity Plan). CIncinnati, ohlo.The C.A.Aregory Company, 1937 (Revised Edison).

8. Burr, Samuel Engle. A School in Transition. Boston, The Christopher Publishing House, 1937.

9. Burr, Samuel Engle. What is the Activity Plan of Progressive Education? Cincinnat1, The C.A.

10. Carey, Allce; Hanna,Paul R.; and Mer lam, J.I. Catalogue of Units of Work, Activities Project Themes. (The Lincoln School Ser10s). New York C1ty. The Bureau of Publication, Teachers College, Columbia University, 1932.

11. Hissong, Clyde. The Activity Movement. Baltimore. Warw Ick and York, Inc., 1932.

12. Kilpatrick, William H. Foundations of Methad. New C1ty. The MacMilian Company, I925.

13. Kilpatrick, Wliliam H. Education For a Changing Civilization. New York C1t $y$. The MacMlilan Company, 1931. 
14. Kilpatrick, William $f_{0}$, and Others. The Educational Frontier. New York Clty. The Century Company, 1933.

15. Lane, Robert Hill. A Teacher's Gulde Book to the Act1vity Program. New York C1ty. The Macm1Ilan Company, 1932。

16. Mead, Cyrus D., and Orth, Fred W. The Transitional Public school. New York City. The MacMllian Company, 1934.

17. Mearns, Hughes. Creative Youth. Garden City, N.Y., Doubleday, Doran and Company, 1925.

18. Mearns, Hughes. Creative Power. Garden City, N.Y., Doubleday, Doran and Company, 1929.

19. MeIvin, A.Gordon. Progressive Teaching. New York City. D. Appleton and Company, 1929.

20. Melvin, A. Gordon. The Technlque of Progressive Teaching. New York CIty. The John Day Company. 1932.

21 Melvin, A.Gordon. The Activity Program. New York City. Reynal and Hitchcock. 1936.

22. Naumburg, Margaret. The Walden School. Twenty-Sixth Yearbook of the National soclety for the study of Education. 1926 Part I.

23. Porter, Martha Peck. The Teacher in the New School. Yonkers-on-Huds on. The WorId Book Company, 1930.

24. Prossey, S.I. Psychology and the New Education. Now York City. Harper and Brothers. 1933.

25. Rugg, Harold $0 .$, and Shumaker, Ann. The Ch1ldCentered School. Yonkers-on-Hudson. The World Book Company. 1928.

26. Stevens, Marion Paino. An Activities Curriculum in Primary Grades. Boston. D.C.Heath and Company. 1931.

27. Storm, Grace E. The Social Studies in the Primary Grades. Chicago. Iyons and Carnahan. 1931.

28. Taba, Hilda. The Dynamics of Education. New York. Harcourt, Bruce and Company, 1932. 
29. Thayer, V1vian T. The Passing of the Recitation. Boston. D.C.Heath and Company. 1928.

30. Tippett, James S. (Editor) Curriculum Making in an Elementary School. Boston. Ginn and Company, 1927.

31. Washbourne, Carleton. Adjusting the School to the Ch11d. Yonkers-on-Hudson. The WorId Book Company, 1932.

32. Wright, Lula E. A First Grade at Work. New York city. The Bureau of PubIIcations. Teachers College. Columbia University. 1932.

33. Wright, Pearl M. "Comparative Effectiveness of the Activity Program and Traditional Program as Methods of Primary School Procedure." UnpubIished Master s Thes18. Teachers College. Un1versity of Cincinnati. 1929.

34. Wrightstone, J. Wayne. Appra1sal of Newer Practices in Selected Public schools. New York City. The Burequ of Publications. Teachers College. Columbla University. 1835.

\section{Yearbooks}

35. National Society for the Study of Education, Twenty-sixth Yearbook. Part I. Bloomington, Public School Publishing Company, 1926.

36. National soclety for the Study of Education, Thirty-third Yearbook. Part II. "The Activity Movement." Bloomington, Public School Publishing Company, 1934.

\section{Perlodical:}

37. Brim, Orville G., Basic Realities and the Activity Movement. Progressive Education. Volume 11; 1934. pp.328-333.

38. Dengler, Paul L., Creative Personality and the New Education. Progressive Education. Volume 6,1929 . pp.132-135. 
39. Gray, William S., Cont roversial Is sues Relating to the Activity Curriculum. Progressive Education. Volume 11, 1934. pp. 334.339.

40. Kilpatrick, William H., The Essentials of the Activity Movement. Progressive Education. Volume 11. pp.346-359.

41. Meriam, J.I., An Activity Curriculum in a School of Mexican Chlldren. Journal of Experimental Education. VoIume 1 . pp. 309-315.

42. Whipple, Guy M., The Activity Movement from an Adverse Point of View. Propressive Education. Volume 11. pp.340-345. 